
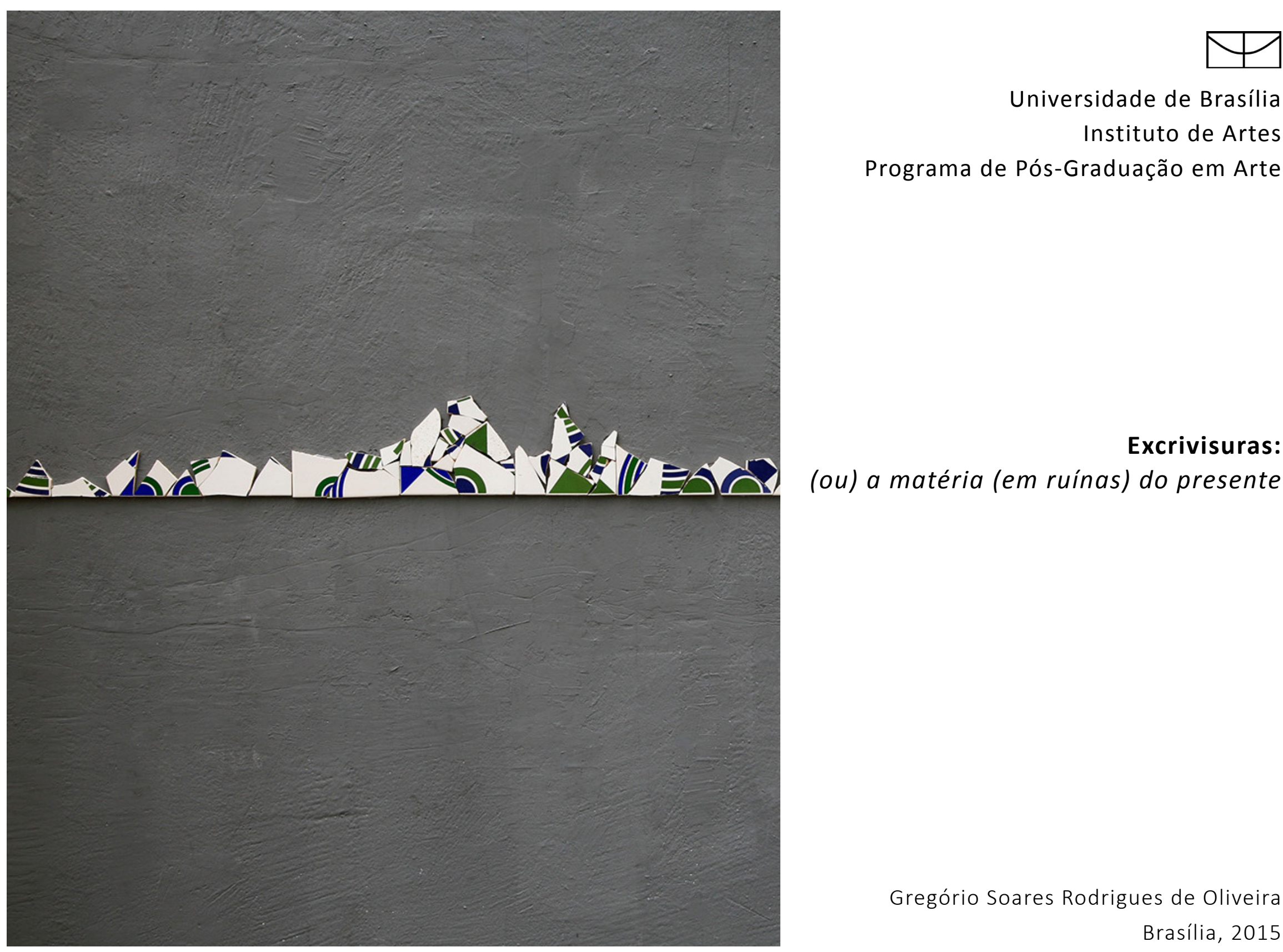

Universidade de Brasília Instituto de Artes Programa de Pós-Graduação em Arte

Excrivisuras: (ou) a matéria (em ruínas) do presente 


\title{
Excrivisuras:
(oul a matéria (em ruínas) do presente \\ (ou) a matéria (em ruínas) do presente
}

\begin{abstract}
Dissertação apresentada ao
Programa de Pós-Graduação em

Arte da Universidade de Brasília, como requisito parcial para a
\end{abstract} obtenção do grau de mestre em Arte.

Linha de pesquisa:

Poéticas Contemporâneas

Orientador:

Prof. Dr. Vicente Martinez 
Ficha catalográfica elaborada automaticamente,

com os dados fornecidos pelo(a) autor(a)

\begin{tabular}{|c|c|}
\hline \multirow[t]{3}{*}{ SOL $48 \mathrm{e}$} & $\begin{array}{l}\text { Soares Rodrigues de Oliveira, Gregório } \\
\text { Excrivisuras: (ou) a matéria (em ruínas) do } \\
\text { presente / Gregório Soares Rodrigues de Oliveira; } \\
\text { orientador Vicente Martinez. -- Brasilia, 2015. } \\
\quad 167 \text { p. }\end{array}$ \\
\hline & $\begin{array}{l}\text { Dissertação (Mestrado - Mestrado em Artes) -- } \\
\text { Universidade de Brasília, } 2015 \text {. }\end{array}$ \\
\hline & $\begin{array}{l}\text { 1. Metodologia em Arte. 2. Escrita de Artista. } 3 . \\
\text { Poética. 4. Ruína. 5. Fotografia. I. Martinez, } \\
\text { Vicente, orient. II. Título. }\end{array}$ \\
\hline & \\
\hline & \\
\hline
\end{tabular}



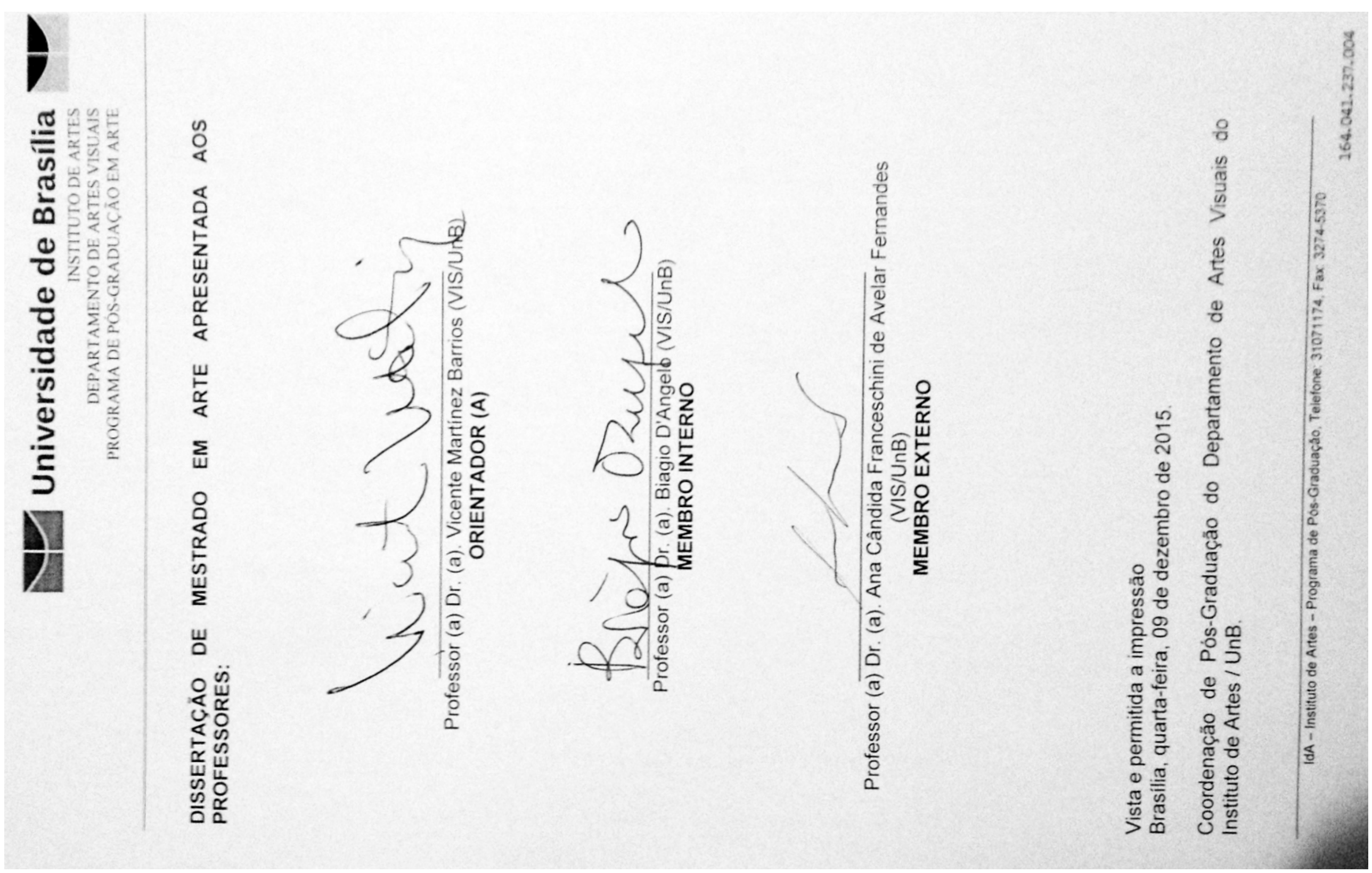


\section{Agradecimentos}

A minha família pelo amor incondicional.

Ao meu orientador, Vicente Martinez, pela abertura, pelo olhar luzidio, pelas palavras sem "fofismos", e pela compreensão, fundamentais a este trabalho.

A banca de qualificação, Professores Biagio D'Angelo e Ruth Sousa, pelas atenciosas leituras primeiras.

Aos que pontualmente, de diferentes formas, fizeram este percurso possível, pelas trocas afetivas e intelectuais: Atila Regiani, Dalton Camargos e Alfinete Galeria, Rita Almeida, Yana Tamayo, Ananda Giuliani, Isadora Dalle, Léo Tavares, Lucas Lyra, Cláudio Mattos, Ludmilla Alves, Matias Monteiro, David Almeida e Annima de Mattos, Dani Gutfreund, Bruno Kurru e ao Elefante Centro Cultural.

Ao Grupo de Pesquisa Escritura: Linguagem e Pensamento e ao Professor Piero Eyben, por me proporcionarem o tortuoso e urgente pensamento da escritura.

A Luis Pérez-Oramas pelo subtítulo deste trabalho e por tudo que frutificou em nossos dialogos lejanos, que é para mim incomensurável.

A Valéria Prates, retroativo, por ter me recebido um dia, proporcionando-me caminhar "fora da linha" e aprendido tanto sobre o que viria a ser o meu objeto primeiro.

Ao meu irmão Thales Noor, pelo apoio e amizade resistentes e nobres como rocha.

A Nina Trindade pelo retorno e ao porvir em comum, fruto de nós.

A Coordenação de Aperfeiçoamento de Pessoal de Nível Superior - CAPES, pela bolsa de pesquisa viabilizadora deste projeto. 
O objeto de pesquisa desta dissertação compreende a especificidade da pesquisa em arte, bem como suas implicações metodológicas que se caracterizam por exigir uma abordagem distinta para cada "artistapesquisador". O resultado de tais abordagens implica tanto as decisões escriturais quanto as imagéticas, interseccionando, assim, os campos de atuação da imagem e da palavra em uma discussão, ao mesmo tempo, teórica e prática da linguagem poética. Diante disso, este trabalho propõe um conjunto de eixos temáticos para que seja possível discutir e contextualizar as especificidades da pesquisa artística referente às questões que envolvem: 1) uma escrita com enfoque teórico sobre o pensamento da criação artística; 2) as relações entre as produções escrita e imagética, prática e conceitual, no mesmo contexto; e, 3) a interseç̧ão entre artes visuais e poesia dentro de uma "poética contemporânea". Os eixos se subdividem em três abordagens, que discutem mais objetivamente os seguintes pontos: 1) o escrever sobre a imagem e sua relação com o desenho; 2) uma reflexão sobre os processos de elaborações poéticas do autor e sua relação com os conceitos de fragmento e ruína; e, 3) a abertura produzida pela fotografia como escrita imagética e sua relação com o conceito de tempo.

Palavras-chave: pesquisa em arte; escrita de artista; poética; ruína; fotografia. 
This dissertation's subject matter comprises the specificity of art investigation, as well as it fits the requirement that each methodological approach should be different to each researching artist. The result of such different approaches entails imagistic and scriptural decisions alike, thus intersecting the fields in which the image and the word perform to engage a debate about poetic language, at once pragmatically and theoretically charged. The following paper proposes a set of thematic perspectives so that the discussion and contextualizing of this investigation's specificities may be possible; they comprise in: 1) a writing whose theoretical focus is upon thinking on artistic creation; 2 ) the correlation between written and imagistic confections both practical and conceptual in the same context; and also 3) the intersection between the visual arts and poetry with in "contemporary poetics". Furthermore, these perspectives subdivide in three lines of approach that discuss more objectively the following topics: 1) writing about the image and its interface with drawing; 2 ) a reflection upon the author's creative process and its connection with the concepts of fragment and ruin; and lastly, 3) the aperture produced by photography as imagistic writing and its intercourse with the concept of time. 


\section{Índice de imagens}

Figura 1: Gregório Soares, Pairos e outras ruínas para J.D., fotografia, xerox sobre transparência e desenho, 30 × 24 cm, 2014.

Figura 2: Gregório Soares, Pairos e outras ruínas para J.D., fotografia, xerox sobre transparência e desenho, 30 × 24 cm, 2014.

Figura 3: Gregório Soares, Pairos e outras ruínas para J.D., fotografia, xerox sobre transparência e desenho, 30 × 24 cm, 2014.

Figura 4: Gregório Soares, Pairos e outras ruínas para J.D., fotografia, xerox sobre transparência e desenho, 30 × 24 cm, 2014 .

Figura 5: Gregório Soares, Pairos e outras ruínas para J.D., fotografia, xerox sobre transparência e desenho, 30 × 24 cm, 2014.

Figura 6: Gregório Soares, Pairos e outras ruínas para J.D., fotografia, xerox sobre transparência e desenho, 30 × 24 cm, 2014 .

Figura 7: Timm Ulrichs, Text, s/d.

Figura 8: Mira Schendel, série Escritas, Monotipia, 1965, 46 × 23 cm (un.).

Figura 9: Kazimir Malevich, Black Square, óleo sobre tela de linho, 79,5 x 79,5 cm, 1915.

Figura 10: Gregório Soares, Ex-truturas, óleo sobre fotografia impressa em papel, $120 \times 90 \mathrm{~cm}$ (un.), 2011.

Figura 11: Gregório Soares, Ex-truturas (vista da obra montada), 17오 Salão Anapolino de Arte, 2011.

Figura 12: Gregório Soares, Autorretratos: estruturas equívocas, fotografia, 45 × 32 cm, 2011. 

cm (un.), 2011.

Figura 14: Gregório Soares, Pilotis: estruturas equívocas, foto-colagem, 30 × $25 \mathrm{~cm}$, 2011.

Figura 15: Gregório Soares, Pilotis: estruturas equívocas, foto-colagem, tríptico, 30 x 25 cm (un.), 2011.

Figura 16: Gregório Soares, Fissuras: estruturas equívocas, fotografia, 50 x $50 \mathrm{~cm}$, 2012.

Figura 17: Gregório Soares, Fissuras: estruturas equívocas, fotografia, 50 x $70 \mathrm{~cm}$, 2012.

Figura 18: Gregório Soares, Paisagem tétrica II: coleção de cacos (ou, rodapé), detalhe, mural/site-specific, .30 x 8 m, 2015 .

Figura 19: Gregório Soares, Paisagem tétrica II: coleção de cacos (ou, rodapé), detalhe, mural/site-specific, .30 x 8 m, 2015 .

Figura 20: Gregório Soares, Paisagem tétrica II: coleção de cacos (ou, rodapé), mural/site-specific, .30 x 8 m, 2015 .

Figura 21: Gregório Soares, Paisagem tétrica, detalhe, site-specific, .30 x 5 m, 2014.

Figura 22: Gregório Soares, Paisagem tétrica, site-specific, . 30 × 5 m, 2014.

Figura 23: Geraldo de Barros, sem título, fotografia, 1951.

Figura 24: Gregório Soares, registro de processo, 2015

Figura 25: Gregório Soares, Paisagem tétrica II: coleção de cacos (ou, rodapé), detalhe, mural/site-specific, $.30 \times 8 \mathrm{~m}, 2015$

Figura 26: Gregório Soares, Paisagem tétrica, registro de processo, 2014.

Figura 27: Gregório Soares, Paisagem tétrica, registro de processo, 2014. 
Figura 35: Gregório Soares, Pairos (montagem no Pivô - Edifício Copan, São Paulo), fotografia, 2014. artista para 30ạ Bienal de São Paulo, 2012.

Figura 41: Gregório Soares, Pairos (detalhe), fotografia, 2014. 
E eis que me tornei um desenho de ornamento

Volutas sentimentais

Volta das espirais

Superfície organizada em preto e branco

E no entanto acabo de ouvir-me respirar

É isso um desenho?

Isso sou eu?

Pierre Albert-Birot, Poèmes à l'autre moi 
Sumário

- Índice de imagens

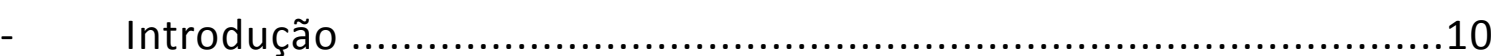

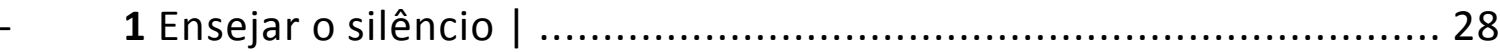

1.1 excrivisuras, escrever o ver:

um desenho para os limiares da imagem-escrita

2 Triscar a ruína |

2.1 a imagem presente por um triz:

um fragmento em abismo

3 Pairar o retorno |

3.1 os rastros dos sentidos:

uma grafia errante das luzes perdidas

- $\quad$ Considerações avir 


\section{Introdução}

Muitas vezes me acontece, escrevendo, ter a impressão de que cada uma das expressões por mim proferidas é só uma tentativa, uma aproximação, um esboço; ou então de que estou trabalhando no meio ou através do dicionário, um pouco como a toupeira, jogando fora as palavras, expressões, abrindo caminho através delas, apesar delas mesmas. De modo que minhas expressões me aparecem mais como materiais rejeitados, como um entulho, e a própria obra, no limite, como o túnel, a galeria, ou enfim o cômodo que cave na rocha, mais do que como uma construção, um edifício, ou uma estátua.

(...) e a variedade das coisas é, na realidade, o que me constrói. O que eu estou querendo dizer é o seguinte: sua variedade me constrói, me permitiria existir até mesmo no silêncio.

Francis Ponge, Cristais Naturais

Para onde eu iria, se pudesse ir, o que seria, se pudesse ser, o que diria, se tivesse uma voz, quem é que fala assim, dizendo que sou eu?

Samuel Beckett, Textos para nada 
Se o objetivo dessa dissertação (ancorada na linha de pesquisa poéticas contemporâneas) é se debruçar textualmente, teoricamente, discursivamente sobre meu próprio trabalho poético, pode-se supor que seu resultado mesmo poderia ser uma obra, ou fazer parte dela? (Afinal, onde começa uma obra?) De outro modo, ampliando a questão, é possível dizer que os textos produzidos por artistas são partes de suas obras? Se sim, por que sim? Se não, do mesmo modo, por quê? Se o que está em questão é o poético, por meio do visual, qual o lugar da escrita? O que está em questão quando se diz "poético"? Se o trabalho da teoria, em poucas palavras, é aquele de olhar através de (como nos indica a etimologia da palavra grega theoreîn = théa [através] + horós [ver]), o que, de fato, diferencia-a da obra de arte, que também provoca um olhar através, um conhecimento por meio do ver dela mesma enquanto um fenômeno ou um acontecimento? É possível supor, desde já, que o problema indicado aqui está situado no antigo, complexo e imbricado tema da relação palavra-imagem e que está presente em grande parte das reflexões artísticas e filosóficas a respeito da representação. Essas são, de fato, questões que provocam a dissertação por vir sem que a tentativa seja a de respondê-las fundamentalmente, mas de algum modo deixá-las em suspensão, em tentativa corrente, sempre à vista, alimentando-as.

Neste sentido, o trabalho que se segue pode ser compreendido como a tentativa pessoal de um movimento que elege o ato e os efeitos da "tentativa" como pressuposto de qualquer feitura (e escritura) do trabalho de arte (ou poético) e do trabalho teórico. Tal movimento tem como lugar a anterioridade constante de toda 
ação, no sentido que as decisões tomadas também estão em pleno processo de revisão, de exame, de ensaio, de introdução, sendo reapresentadas constantemente. Não há um por vir senão que retoma, que volta a um ou mais problemas que não foram resolvidos, ou, até mesmo, e nunca descarta a possibilidade, de não serem resolvidos. Sobretudo porque tais problemas podem se tratar de problemas que não foram tidos como tais; ou seja, neste caso, são invenções de problemas ${ }^{1}$. Ocorre então, e este trabalho é resultado e pesquisa desta ocorrência, um mapeamento de problemas.

O exercício de mapear tais problemas é também o de reconhecer os limites de um dado objeto; este exercício parte da minha experiência com o mundo das poéticas, dos fazeres e dos escreveres e que não me permitem viver sem que retornem; só me resta, portanto, coexistir com o retorno intermitente desses problemas (objetais ou não) e tentar resolvê-los provisoriamente, em diálogo com as tentativas de resoluções de outros que se propuseram o mesmo.

Tal trabalho de tentativa, que sobrevoa a ideia de retorno ${ }^{2}$ enquanto conceito possível, na medida em que se reconhece a recorrência de fatos e

\footnotetext{
1 “(...) os artistas passam o tempo todo inventando problemas - para si próprios, para os outros, para a cultura." Basbaum, R. Pós-galerias. In: "Manual do artista-etc", 2013, p. 54. “(...) o problema é a nossa matéria-prima. Encontrar um bom problema é a nossa primeira tarefa." Tessler, E. Coloque o dedo na ferida... In: "O meio como ponto zero: Metodologias de pesquisa em Artes Plásticas". (Orgs.) Brites, B., Tessler, E. 2002, p. 106.

${ }^{2}$ A questão do "retorno" é tratada de diferentes formas por muitos autores, no terceiro capítulo farei uma seleção e exemplificação desse conceito sob alguns pontos de vista.
} 
interesses, justamente na atividade de revisão de meus próprios trabalhos, se dá, ou poderia ser definida, como a tentativa de um mapeamento das origens, dos meios e dos fins das decisões poéticas nos meus trabalhos. Portanto, a circunscrição im/possível dos objetivos desta dissertação é o trabalho de reconhecimento dos interesses predominantes no conjunto de trabalhos já realizados por mim e, concomitantemente, seguidos de sua reflexão enquanto verificação dos "problemas" que envolvem sua criação e sua escrita a respeito. Ou seja, em três tópicos, assim poderia se resumir (mesmo acreditando que isso não seja suficiente): 1) uma escrita com enfoque teórico sobre o pensamento da criação artística; 2) as relações entre as produções escrita e imagética, prática e conceitual, no contexto da produção artística; 3) e, por fim, a intersecção entre arte e poesia dentro de uma "poética contemporânea" e suas possíveis implicações no contexto de uma produção acadêmica.

Em outras palavras, o objeto aqui debruçado não é tanto o resultado dos trabalhos poéticos já realizados, seguidos de uma contextualização histórica e teórica da arte e mais o questionamento de como é possível pensar sobre o próprio processo de escrita, esse outro fazer, a respeito do primeiro. Ou seja, a pergunta central é: o que é esse exercício de escrita sobre o próprio ato (o meu mesmo) de criação e seus resultados? Dar nomes, portanto, enunciar, designar objetos inominados, mudos ou que tendem ao mutismo, é o objetivo maior aqui e que poderia ser desdobrado em mais questões: como nomear, em termos próprios, aquilo, ou esta produção (a minha) que sempre me escapa? Como escrever sobre 
este objeto (ou "objogo"3 ) que possui existência material, dimensional, mas que ainda é anônimo, "mudo" ${ }^{4}$, e a todo momento se desfigura, desmancha, deforma?

Seria este o lugar/objeto/etc. das poéticas:

- o lugar para se pensar o próprio lugar ou o que é próprio do lugar?

- o objeto para se pensar o próprio objeto ou o que é próprio do objeto?

- a escrita para se pensar a própria escrita ou o que é próprio da escrita?

- a obra para se pensar a própria obra ou o que é próprio da obra?

- a imagem para se pensar a própria imagem ou o que é próprio da imagem?

- (...) existe o que é próprio a algo ou a propriedade-propriamente-própria?

- o que é, se possível, a propriedade-propriamente-própria do poético?

Para este cruzamento, que percorre as questões sobre a linguagem, de caráter teórico, no sentido em que se propõe uma sistematização em diálogo com o

\footnotetext{
${ }^{3}$ Sobre a ideia de "objogo", formulação feita pelo poeta Francis Ponge, cito: "o objeto é aqui o objeto que não se afigura, ou não se afigura de todo, mas se desfigura, se desmancha em partes. (...) 0 objeto parcial, em suma, o objeto que escapa, o objeto ausente. O "objeu" (“objogo"): o objeto enquanto não mais que jogo de linguagem." (Motta, 1997, p. 11).

${ }^{4}$ Refiro-me à "mudez" das imagens tal como propõe Fernand Deligny, em declaração no seu filme "À propos d'un film à faire", 1989, França, $16 \mathrm{~mm}$, no sentido de que quem diz sobre as imagens somos nós, seres falantes; elas, enquanto imagens, são mudas, nuas, não nos respondem com palavras, voz, idioma etc., apenas "conversam" por meio do olhar, de um sistema de visibilidade. Pode-se dizer apenas que realizamos conversas silenciosas com as imagens, neste sentido.
} 
conhecimento das humanidades, e poético, no sentido em que se propõe necessárias articulações dentro da esfera do fazer individual sobre o (ou, um) "próprio" fazer poético, fez-se necessário as propostas de nomeação e enunciação deste trabalho e que desenvolverei ao longo dos três capítulos que se seguirão.

Este ponto de partida, é preciso dizer, são questões que sempre me suscitam ao produzir (pensar e fazer: na práxis) meus trabalhos enquanto "artistapesquisador" ${ }^{\prime 2}$. Por isso, optarei por introduzir a cada capítulo um conjunto desses trabalhos que são significativos (a meu ver) em formato de ensaios (visuais e/ ou textuais), para os tópicos a serem abordados no texto escrito em seguida, norteando-os, portanto. Estruturalmente, assim, os trabalhos referenciais de minha autoria $^{6}$ estarão (quase) sempre no início de cada capítulo, intitulados: 1) ensejar o silêncio; 2) triscar a ruína; e 3) pairar o retorno. Estes, como foi já dito, não são os objetos específicos dos desenvolvimentos, mas sim, onde mora o que eu não posso dizer de outra maneira, ou o que eu não posso dizer, ou ainda, o que me impõe os limites do dizível. Assim, é do silêncio que meus próprios trabalhos (e os trabalhos de outros artistas) me provocam que esta dissertação se motiva e que torna preciso, necessário, urgente, desenhar/designar sobre o escrever, escrever sobre os caminhos do escrever, a partir dos silêncios, das ruínas e dos movimentos de retorno provocados por tais imagens.

${ }^{5}$ Dentro da discussão proposta por Ricardo Basbaum, no texto "O artista como pesquisador" (2013, p. 193).

${ }^{6}$ As imagens de trabalhos referenciais, de outros artistas, também estarão nos ensaios iniciais de cada capítulo, e podem ou não serem tratadas diretamente dentro dos textos. 
Na sequência dos ensaios virão em subtítulos as discussões onde serão tratados os seguintes temas: 1) o dizer e o escrever sobre a imagem e sua relação com o desenho; 2) uma reflexão sobre o processo de elaboração poética e sua relação com a matéria do fragmento e da ruína; 3) a abertura causada pela fotografia como escrita imagética e a perseguição discursiva pelo sentido da imagem. No primeiro ponto, a abordagem será feita a partir da reflexão a respeito da intersecção possível entre desenho e escrita, a palavra enquanto matéria para a imagem, supondo, até então, que os títulos dos meus trabalhos e especialmente o trabalho "outras ruínas para J.D.", 2014, têm se aproximado do discurso verbal, além de seu caráter gráfico, já abstraído. A questão da matéria da imagem em meus trabalhos será tratada no segundo tema, onde o ponto de partida será o interesse pela questão da ruína e do fragmento. No terceiro e último, proponho uma discussão a partir das minhas atuações foto-gráficas, como hipótese de síntese dos temas anteriores, com relação à escrita-desenho e à matéria.

Diante dessas premissas todo este trabalho será desenvolvido tendo como pano de fundo pelo menos quatro figuras-eixo-metodológicas ${ }^{7}$, (que, por si mesmas, me auxiliarão no próprio pensamento metodológico, ou seja: nos caminhos

${ }^{7}$ As figuras-eixo-metodológicas auxiliarão na medida em que os objetivos dessa pesquisa tem como parte a reflexão metodológica mesma no contexto da produção em artes plásticas; neste sentido, há uma inversão na máxima maquiavélica: os meios justificam os fins; que portanto, não deixa de colocar em dúvida a própria ideia de "método" como recurso de pesquisa em artes. 
escolhidos para se chegar aos objetivos ${ }^{8}$, de forma estrutural e conceitual). Tais são:

1) o quiasma; 2) a montagem; 3) o desvio; e 4) a aporia; das quais tentarei discorrer em seguida.

O quiasma, tanto óptico quanto retórico, para compreender que tais questões a serem abordadas estão sempre em um cruzamento, na imagem do " $X$ " ("chi", letra grega de onde o termo quiasma se deriva), em uma encruzilhada, se quisermos, de pontos de vistas, de áreas do saber distintas, que ora se refletem, ora se opõem, outras apenas se cruzam ou partem de um ponto em comum para depois se distanciarem; e, talvez ainda, correm o risco de se perderem nas qualidades distintas de suas origens. Vale ser lembrado o tom que Maurice Merleau-Ponty imprime sobre essa palavra em associação à ideia de "entrelaçamento" 9 na tarefa da reflexão filosófica sobre "o visível e o invisível", cito-o:

Se é verdade que a filosofia, desde que se declara reflexão ou coincidência, prejulga o que encontrará, torna-se-lhe necessário então recomeçar tudo de novo, rejeitar os instrumentos adotados pela reflexão e pela intuição, instalar-se num local em que estas ainda não se distinguem, em experiências que não foram ainda "trabalhadas", que nos ofereçam concomitante e confusamente o "sujeito" e o "objeto", a existência e a essência, e lhe dão, portanto, os meios de redefini-los (Merleau-Ponty, 1992, p. 127).

\footnotetext{
8 "A pesquisa em arte diferencia-se das pesquisas em outras áreas das Ciências Humanas na medida em que seu objeto não pode ser definido a priori, ele está em vir-a-ser e se construirá simultaneamente à elaboração metodológica" (Cattani, 2002, p. 40).

${ }^{9}$ No texto do filósofo a palavra aparece apenas no título, como sugestão: "O entrelaçamento - $O$ quiasma", 1992, p. 127).
} 
É possível dizer, com ou sem pretensões, que a tarefa aqui é similar, se encontra justamente nesse ponto entre o que é possível ver e o que está no pensamento, invisível (aos olhos), portanto, no exercício conceitual, diante de uma série de experiências "problemas" onde o trabalho que se estabelece é o de redefini-los, reapresentá-los, "torná-los visíveis" ${ }^{10}$, compreendendo a trama complexa, muitas vezes indiscernível na qual elas se inserem.

As decisões metodológicas, assim, impõem um paradoxo ${ }^{11}$ no qual é preciso assumir, pois elas não funcionam aqui no seu uso comum, como um caminho "seguro" a adotar, no sentido de uma "chave mestra", de um manual fixo etc.; assim, são instrumentos de viagem que afirmam o "meta-" no seu sentido etimológico, que está para o sentido de "trans", "depois" do caminho, que poderia ser interpretado também como aquilo que está, de alguma maneira, para fora do caminho; ou, que pelo menos, assume no caminho a possibilidade de transpassá-lo, de modificá-lo, de errá-lo, ou por fim, de duvidar do seu caráter "-lógico" e desviá-lo. É mais, assim, um descaminho. As decisões a serem tomadas, portanto, prezam pelo desvio, pela insegurança, pelas dúvidas, pelo erro, pela indecisão, que frequentemente retornam, voltam a aparecer alimentando o trabalho por vir.

\footnotetext{
${ }^{10}$ Conforme sugere a máxima de Paul Klee.

11 "(...) um espaço aberto - um mundo aberto/ a coluna vertebral/ a passagem de um modo de ser a outro/ um modo de ser paradoxal (...)", Anna Bella Geiger (1973), retirado do catálogo "fotografia além da fotografia, 1972 - 2008", Caixa Cultural Brasília, 2010, p. 2-3, grifo meu.
} 
Por esses motivos, a máxima de Walter Benjamin método é desvio incorpora a terceira figura-eixo-metodológica. Visto, por Benjamin, como alternativa para concepção do método de Descartes, para a produção filosófica, como abertura das possibilidades criativa, construtiva e imaginativa, colocando a forma sempre em movimento. Cito-o:

Método é caminho indireto, é desvio. A representação como desvio é portanto a característica metodológica do tratado. Sua renúncia à intenção, em movimento contínuo: nisso consiste a natureza básica do tratado. Incansável, o pensamento começa sempre de novo, e volta sempre, minuciosamente, às próprias coisas. Esse fôlego infatigável é a mais autêntica forma de ser da contemplação. Pois ao considerar um mesmo objeto nos vários estratos de sua significação, ela recebe ao mesmo tempo um estímulo para o recomeço perpétuo e uma justificação para a intermitência do seu ritmo (Benjamin, 1984, p. 50, grifos meus).

Nesse "ritmo" intermitente é onde eu gostaria de identificar e situar o conceito de montagem, dentro do que estou chamando de figuras-eixometodológicas. $\mathrm{O}$ termo, como se sabe, faz analogia ao processo cinematográfico que consiste em selecionar, montar e colar os planos de um filme. Mas é utilizado em outros contextos, como os artístico, literário e filosófico, ou mesmo em abordagens teóricas com distintos fins. Não obstante, é possível apreender, em linhas gerais, que 
o uso do termo esteja sempre ligado à composição de um conteúdo em justaposição fragmentária, compondo ou decompondo uma determinada narrativa. Para um dos principais formuladores dessa questão, o cineasta Sergei Eisenstein, já na primeira metade do século XX, em seus famosos livros $A$ forma do Filme e $O$ Sentido do Filme, “a virtude da montagem consiste em que a emotividade e o raciocínio do espectador interferem no processo de criação" (Eisenstein apud Carone, 1973, p. 192). O que está implícito nessa passagem é que há, sempre, na montagem um "terceiro elemento", o "sentido", fruto da "eclosão" das partes justapostas, um lugar "limite", de "fronteiras" e que não é necessário apenas ver, mas uma recriação por parte do espectador ativo e esta, por sua vez, dependerá de cada repertório individual, marcados pela alteridade. E neste sentido é possível afirmar que a montagem é "um discurso regido pela sintaxe da descontinuidade" (Carone, 1973, p. 191).

Em que sentido, então, o leitor dessa dissertação se perguntará que se está solicitando o comparecimento da "montagem" neste trabalho? Solicita-se pois parto do pressuposto que este é um trabalho em processo ${ }^{12}$, uma trama entreaberta que para ser lida necessita também de uma reconstrução, de um retorno, de uma participação construtiva e seletiva dos procedimentos propostos aqui, em formato dissertativo, mas não só, e exatamente também em formato ensaístico (imagético e discursivo) da matéria. Ou seja, o objeto material, se é mesmo possível chamá-lo

\footnotetext{
12 "Para o artista, a obra é, ao mesmo tempo, um 'processo de formação' e um processo no sentido
} de processamento, de formação de significados.” (Rey, 2002, p. 126). 
assim, é, de um só modo, literal e figurado, é assunto e substância para a composição em justaposição. Remeto, neste sentido, a uma passagem de uma entrevista do artista Antonio Dias, sobre a matéria de fazer/ver a pintura ou da obra de arte, que nos convém aqui, de alguma maneira:

Para mim, é mais do que simplesmente uma superfície bidimensional de representação, ele é, enquanto matéria, tão física quanto qualquer outra coisa. Então o que procuro, é criar uma relação entre a matéria do objeto e a matéria que o observador traz de si durante a experiência do observar. A minha ideia era representar algo que fosse de ser e de não-ser ao mesmo tempo (Dias, 1994, p. 15).

A "matéria" indicada no título deste trabalho, diante disso, desse aspecto que é e não é, ao mesmo tempo, para dizer com Antonio Dias, parte desse pressuposto assumidamente intricado do termo. Por um lado, o figurado que estou tentando abordar é a matéria como disciplina, ou seja, seu conteúdo (o que se escreve de uma imagem); por outro, é a materialidade residual, literal do termo, o que ocupa espaço para a física, uma substância corpórea (com o que, como e onde se inscreve uma imagem).

O problema colocado está de acordo que, normalmente, quando se escreve sobre uma imagem já não é a própria imagem mas outra imagem que se cria. “De onde vem essa diferença, essa margem inconcebível entre a definição de 
uma palavra e a descrição da coisa que a palavra designa?" (Ponge, 1997, p.21) perguntaria Francis Ponge. O resultado, de algum modo, pode ser que o "discurso sobre a obra e discurso da obra" (Motta, 1997, p. 11) se confundam. E este é o dado aporético que gostaria de propor como quarta figura-eixo-metodológica que elegi para este trabalho.

A figura da aporia é justamente escolhida, se assim posso dizer, como lugar de morada ${ }^{13}$ deste trabalho. $E$ foi assim elegida por sua fundamental história no pensamento sobre os limites do próprio pensamento e da filosofia, desde a Antiguidade aos dias atuais. Famosa por suas noções gregas implicadas na obra de Aristóteles (sIV a.C.), nos impasses e nas contradições lógicas insuperáveis propostas por Zenão de Eleia (sV a.C.) até convir ao desenvolvimento da reflexão daquilo que se chamou a "desconstrução" na filosofia contemporânea de Jacques Derrida (1930-2004).

A aporia, então, é o lugar onde se instaura uma não-saída (do grego aporos, onde o "a" marca a negação, e "poros" sugere caminho, saída, via, ou ainda, o ato de nascer). Sempre que se propõe, então, um pensamento que escolhe a "via

13 Utilizo-me deste termo para remeter ao Seminário chamado "Demoras na aporia: bordas do pensamento e da literatura", que se dedicou à essa questão "de-morada", organizado em 2012 pelo grupo de pesquisa Escritura: linguagem e pensamento, do Dep. de Teoria da Literatura e Literaturas da Universidade de Brasília, coordenado pelo Prof. Piero Eyben, no qual sou integrante desde o mesmo ano e tem me possibilitado pesquisar este e vários outros conceitos ligados à estética e à poética, bem como questões entre a ética e a estética na filosofia francesa contemporânea. 
paradoxal", como aqui, "a ser pensado dentro da lógica da linguagem poética" (Eyben, 2012, p. 8-9), se instaura também o exercício do pensamento contínuo, ou, como propõe Eyben ainda, "o entorno de um pensamento, um caminho que não se dá senão como em torno de algo, de um objeto inominável, eis um ponto da aporia". Ou seja:

A aporia é sempre um margeado, um estar-se já deslocado da finalidade de uma decisão simploriamente aceita (...) Antes de tudo, a aporia impossibilita. (...) A aporia não concede e, portanto, não cede a quaisquer determinações resolutas, coloca-se não apenas como uma negação da saída, mas como uma espécie de murmúrio infinito da indecisão (2012,

p. 9).

Assim, o caminho que proponho percorrer aqui é exatamente este que aponta para uma não-saída. Um caminho que abre caminho para o pensamento sobre "o" fazer, ou para o pensamento sobre o "como" fazer, sendo a escrita uma feitura também, uma prática do pensamento sobre outro fazer e/ou sobre ela mesma. Essa escritura ${ }^{14}$, essa prática poética, esse fazer artístico, frente à "tela" ou à "folha em branco", "à beira do abismo ou do caos", como disse Derrida, "diante

\footnotetext{
${ }^{14}$ Sobre a questão (ou o problema) da "escritura" especificamente retornarei mais longamente nos
} capítulos 1.1 e 1.3 
do horizonte mais indeterminado, mais angustiante, quando, parece, tudo deve ser repensado, redecidido, refundado de fio a pavio e ali onde talvez o fundo, o fundamento e a fundação venham a falhar" (Derrida apud Bernardo, 2012, p. 23), é onde sobrevive a tarefa do pensamento-feitura, e é quando sempre retornam as antigas questões, atormentadoras: "o que fazer? o que escrever? quem escreve? de onde? como? etc.".

Todo esse des-caminho, esse des-caminhar em contínuo, em viagem, essa locomoção proposta aqui (e para isso solicito as quatro figuras-eixo-metodológicas), é possível dizer, é a mesma que proponho em todas as minhas feituras (chamemo-las de poética, artística ou teórica), no sentido em que compreendo todas essas "linhas" como desenho e todas essas "composições" como pintura, no mesmo instante em que é também um corpus escrito (e ex-crito ${ }^{15}$ ); solicitando que este exercício é uma tentativa de, por um lado, definir (no sentido de traçar, separar) e, por outro, de borrar ${ }^{16}$ (no sentido de juntar, vincular ${ }^{17}$ ) determinadas compreensões. E este exercício quase dialético, se posso dizer, pronuncia muito sobre a oscilação dos caráteres gráfico e pictórico em meus trabalhos, que tentarei abordar ao longo dos capítulos.

\footnotetext{
${ }^{15}$ Idem nota 14, sobre a questão da "ex-crita".

${ }^{16}$ Utilizo as expressões "definir" e "borrar" para remeter à antiga dualidade conhecida entre desenho e pintura, tratada por, dentre outros, Heinrich Wölfflin, em Conceitos Fundamentais de História da Arte, 2006, p. 25-72.

17 "Vincular" no sentido do conceito de vínculo: fazer correspondências, atar diferenças. Sobre este conceito remeto à obra Os vínculos, do filósofo Giordano Bruno (1548-1600), 2012.
} 
São aberturas de espaço no tempo, portanto, causadas pelo ato de me colocar a pensar sobre as questões "materiais" do meu trabalho. Não é o objeto, assim, encontrar respostas para ele, "é ser e continuar a ser questionado por ele, de se suster pela meditação 'em resposta' com ele, sem neutralizar pela explicação o seu poder de inquietação. (...) O tempo permanece aqui incontrolável..." (Lyotard, 1997, p. 81). É a tarefa de tantos outros e é a minha, é essa escrita, "uma peregrinação no deserto", como diz Lyotard, em sua tarefa também (mas de reflexão e escrita sobre o tempo moderno), "não podemos escrever sem testemunhar este abismo que é o tempo, quando chega" (idem, p. 80).

Este "tempo", esta "matéria" do tempo presente, por isso urgente, este "querer dizer/fazer" suponho, em ruína, fazem parte dessa "tentativa" aqui, à minha maneira, junto à de tantos outros. É para tratar desta "matéria" difícil, entranhada no meu corpo, nos meus trabalhos, na minha experiência, na história,

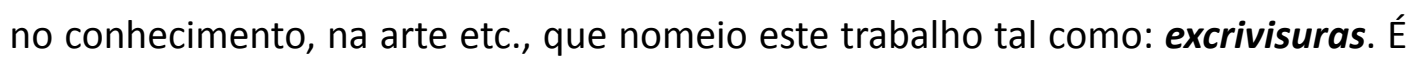
por meio deste substantivo inventado, objeto principalmente do primeiro capítulo, unido estranhamente pelas origens em partes, em pedaços, das palavras "ex", "escrever", "ver" e "visar", que gostaria de trazer as questões sobre a imbricada relação da escrita com a imagem, do escrever com o ver, do pensar com o fazer, enfim, desta matéria onde a linguagem funciona, retorna, torna e, por vezes, tentarei mostrar, parece deixar de funcionar.

Portanto, no imperativo da escritura, que é sempre uma inscrição no mundo, na urgência testemunhal do "é preciso dizer!", junto à dúvida e ao prazer do "o que 
dizer/fazer?", como convite ao porvir dos capítulos seguintes, talvez um convite à espera, infinita, ao prazer da espera em comunidade, juntos, que proponho como fim provisório da introdução, tendo em vista, à vista, isto que nos deixou Lyotard, em seu "próprio" contexto:

a escrita é mergulhada no campo das frases, por onde avança à custa de tentativas, de ensaios, ao encontro do que "quer dizer" e não ignorando nunca, quando pára, que o que fez foi suspender por um instante (que pode ser toda uma vida) a sua exploração e que, para além, desta escrita parada, estão uma infinidade de palavras, de frases e de sentidos latentes, sofredores talvez, e tantas coisas "para dizer" como no princípio.

(...) Este lançamento do vazio, esta evacuação, contrariando uma atividade identificatória, seletiva, conquistadora, não são conseguidos sem sofrimento.

(...) Não desbastamos o terreno para construir com mais luz, entreabrimos uma clareira onde a penumbra do quase dado poderá entrar e modificar o seu contorno (Lyotard, 1997, p. 25-26-27). 
1 Ensejar o silêncio ${ }^{1}$

${ }^{1}$ Este primeiro ensaio é dedicado à coleção dos títulos das séries dos meus trabalhos de 2011 a 2015 , junto aos detalhes dos respectivos trabalhos. Em seguida, uma seleção de imagens do trabalho intitulado "outras ruínas para J.D.", 2014, realizado no Memorial Darcy Ribeiro - Beijódromo, UnB, em ocasião do Colóquio Cada vez, o impossível, Jacques Derrida - 10 anos depois. 

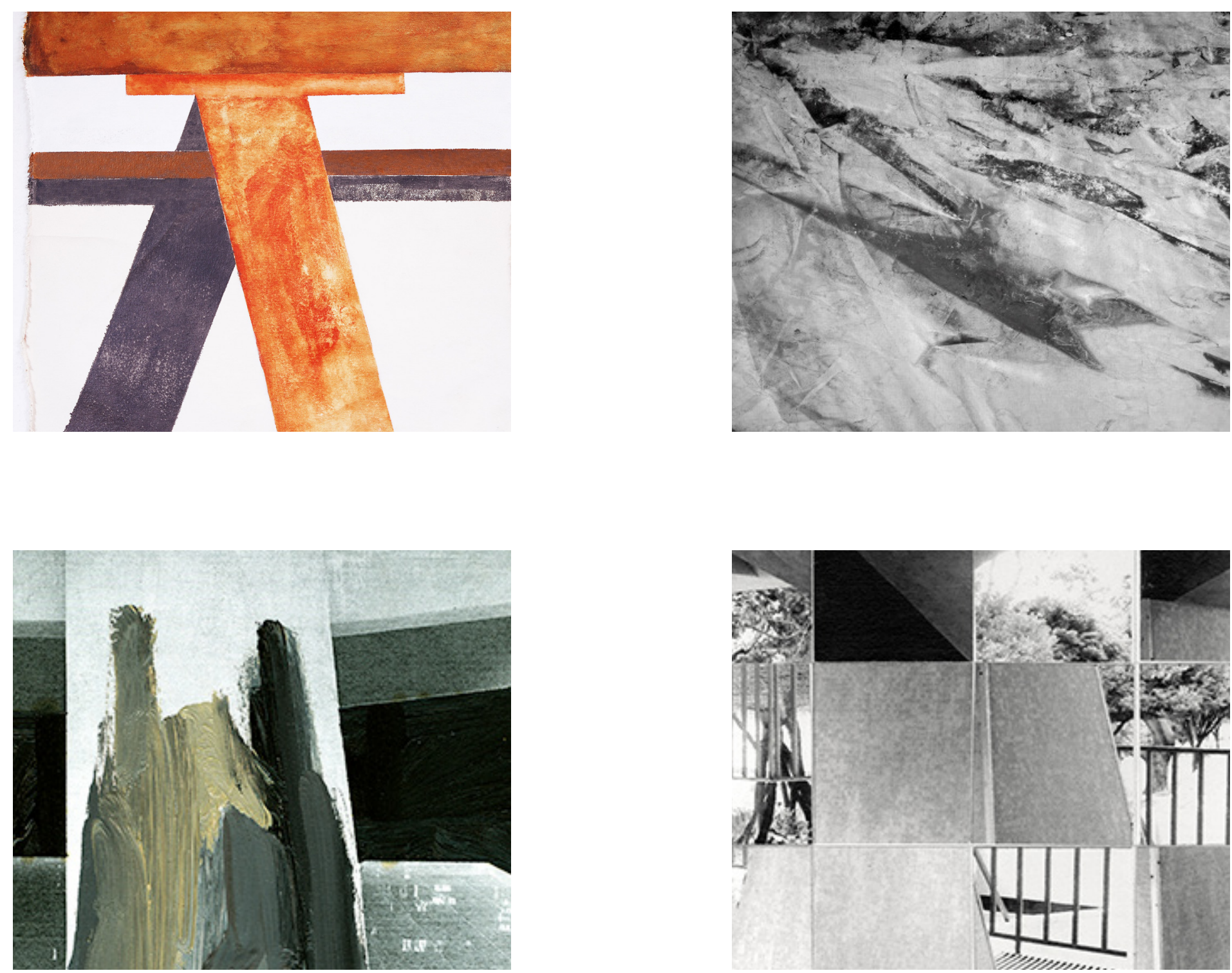
ex-truturas

fotografia e pintura

ano: 2010

pilotis: ex-truturas

I

fotografia e pintura

ano: 2011 diálogos (im)possíveis

I

fotografia

ano: 2011

pilotis: estruturas equívocas

colagem e fotografia ano: 2011 

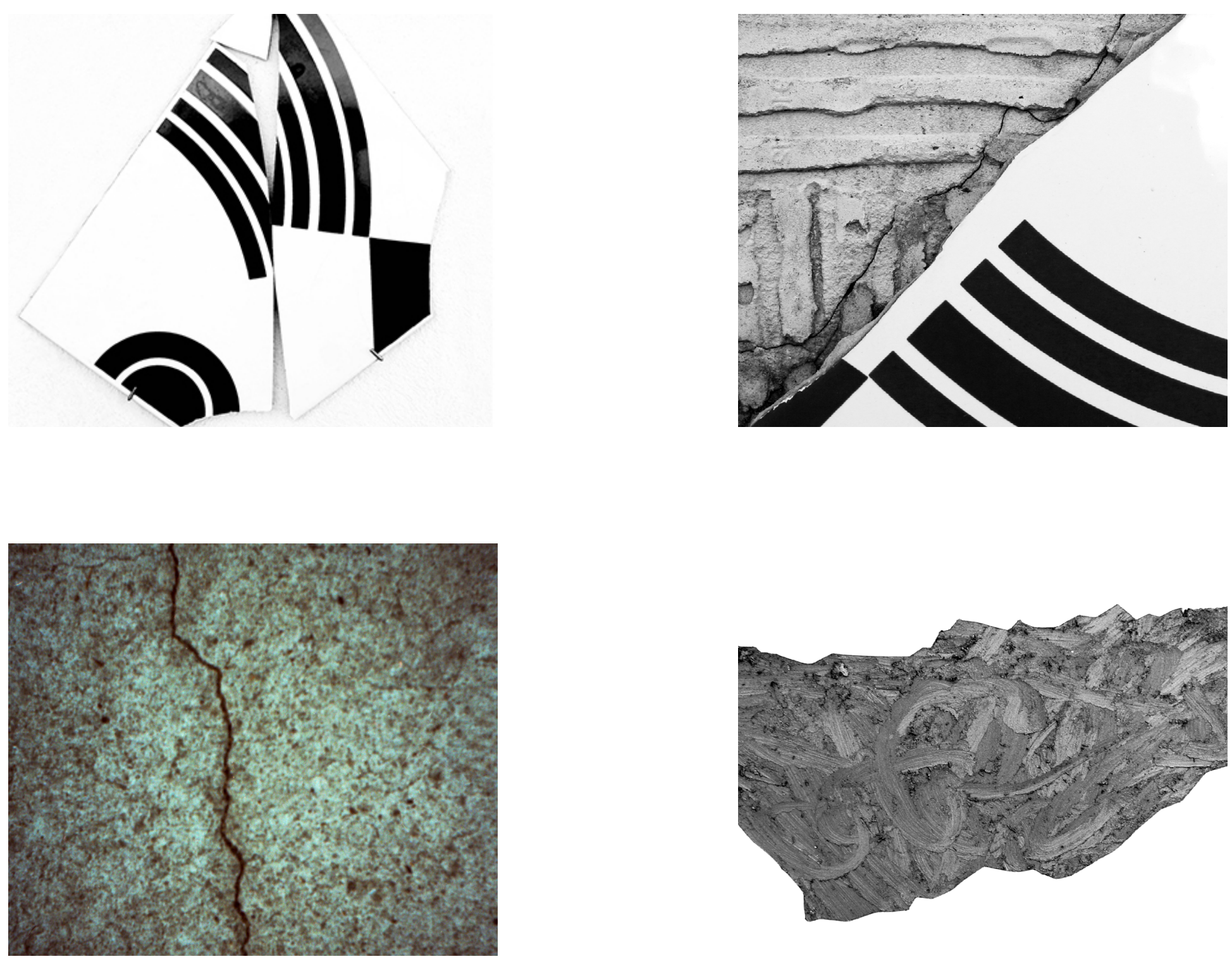
autorretratos: estruturas equívocas

assemblagem e fotografia

ano: 2011

pairos / intermitências / respiros fissuras: estruturas equívocas

I

fotografia

ano: 2012

paisagem tétrica I e II

pintura / intervenção ano: 2014 

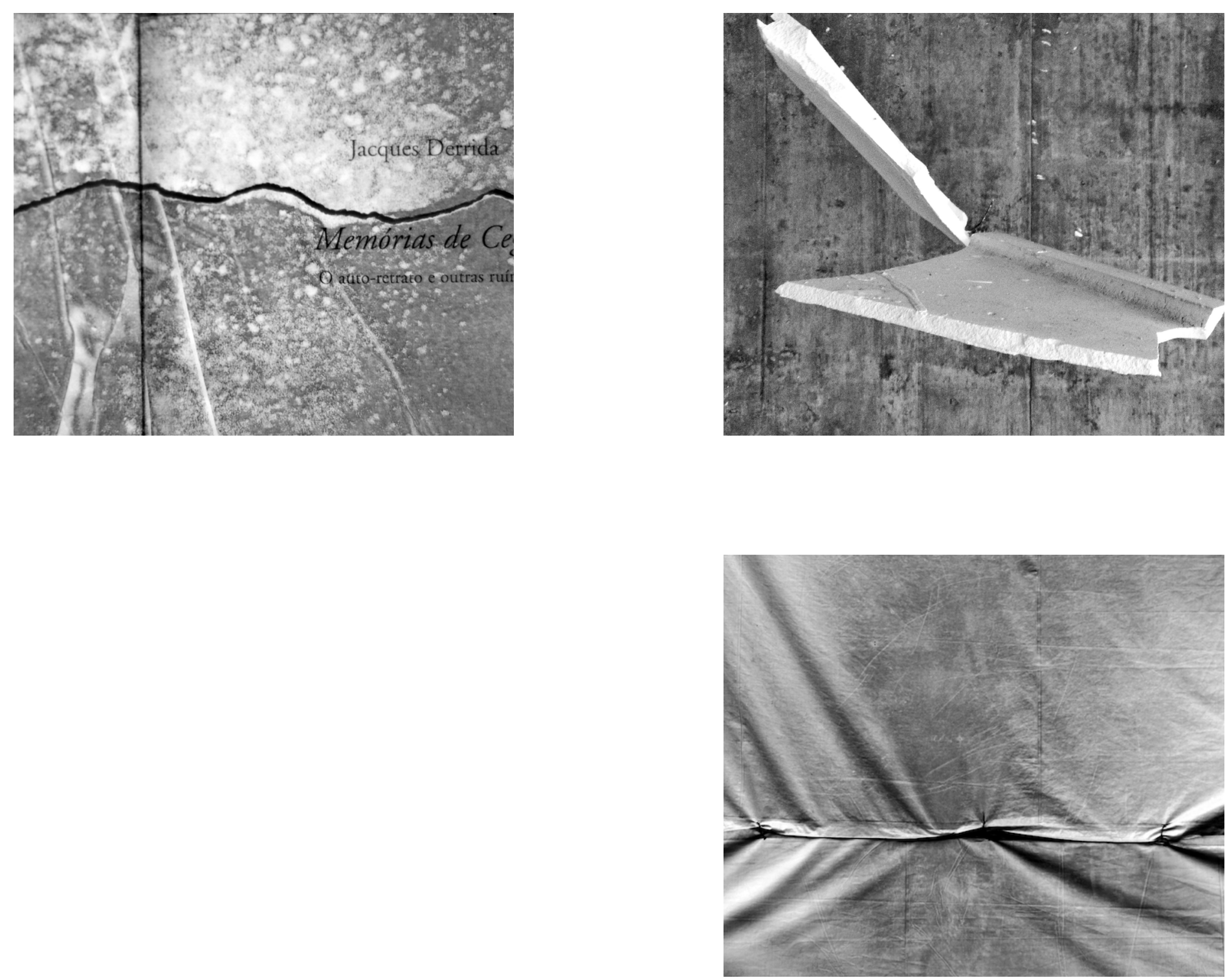
outras ruínas para J.D.

intervenção

ano: 2014 arquipélagos verticais

$$
\text { I }
$$

fotografia

ano: 2015

runas-rugas

fotografia

ano: 2015 
pairos e outras ruínas para J.D. ${ }^{1}$

intervenção

fotografia, xerox sobre transparência e desenho ano: 2014 


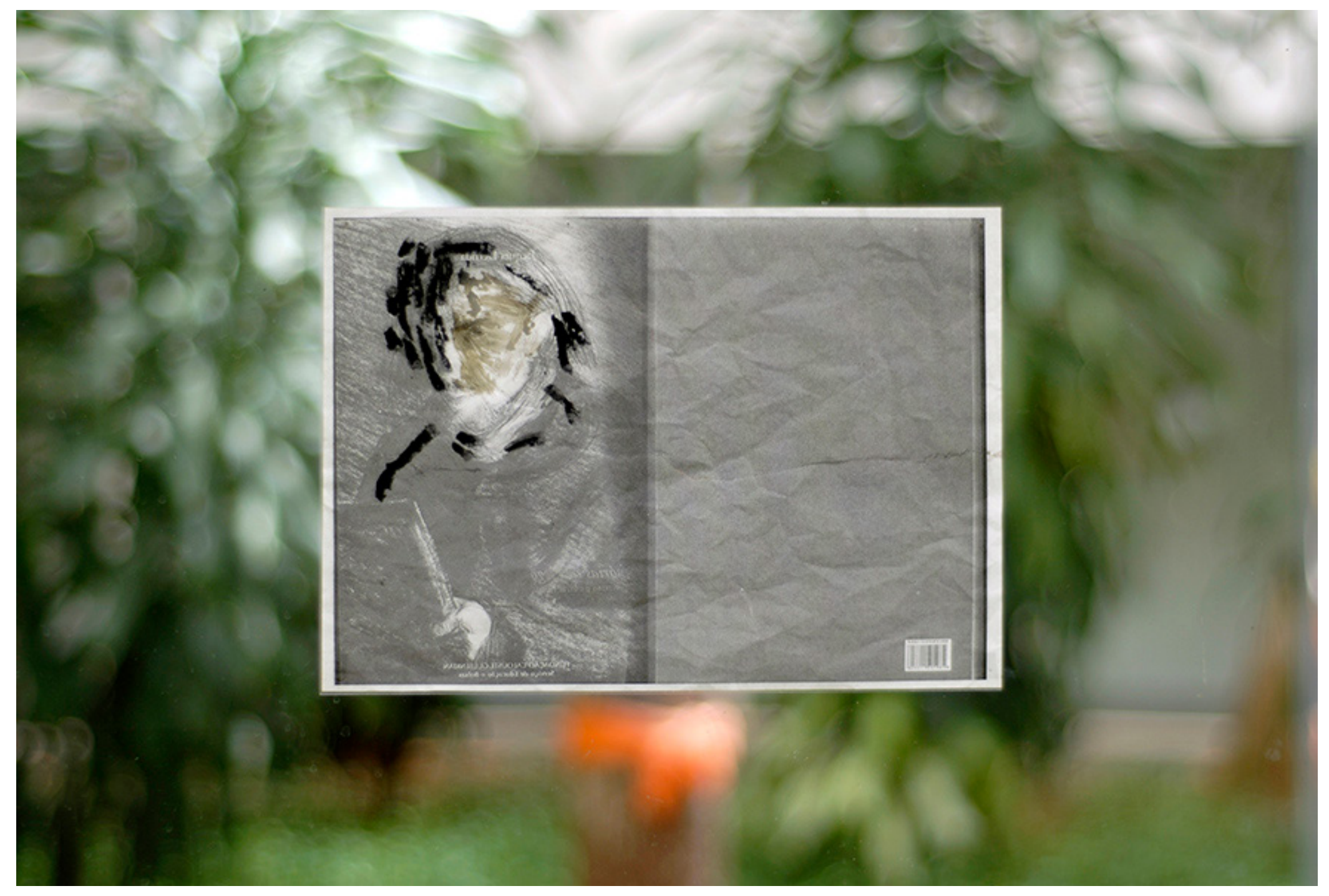

Figura 1: Gregório Soares, Pairos e outras ruínas para J.D., fotografia, xerox sobre transparência e desenho, 30 x 24 cm, 2014 . 


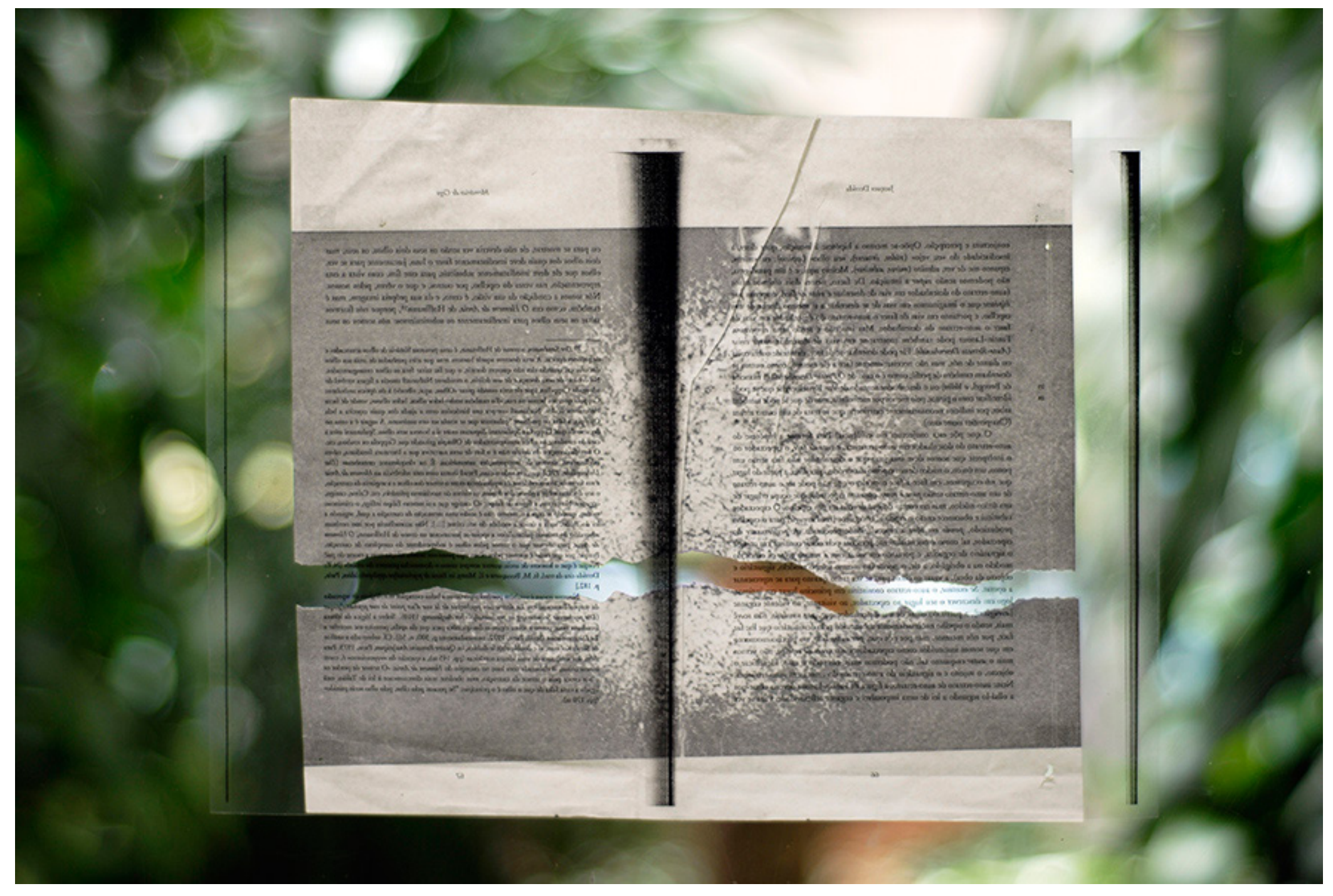

Figura 2: Gregório Soares, Pairos e outras ruínas para J.D., fotografia, xerox sobre transparência e desenho, 30 x 24 cm, 2014 . 


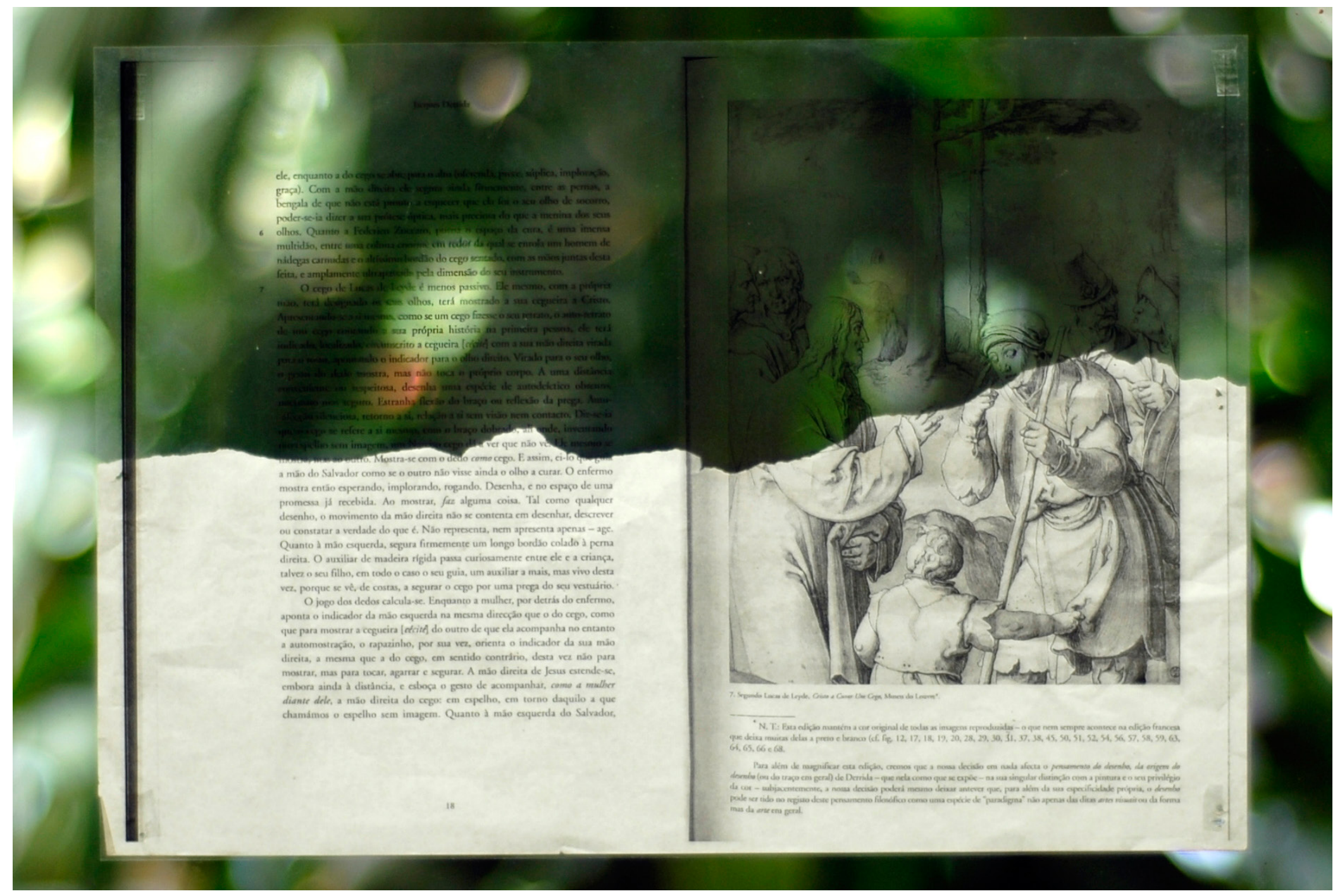

Figura 3: Gregório Soares, Pairos e outras ruínas para J.D., fotografia, xerox sobre transparência e desenho, 30 x 24 cm, 2014 . 


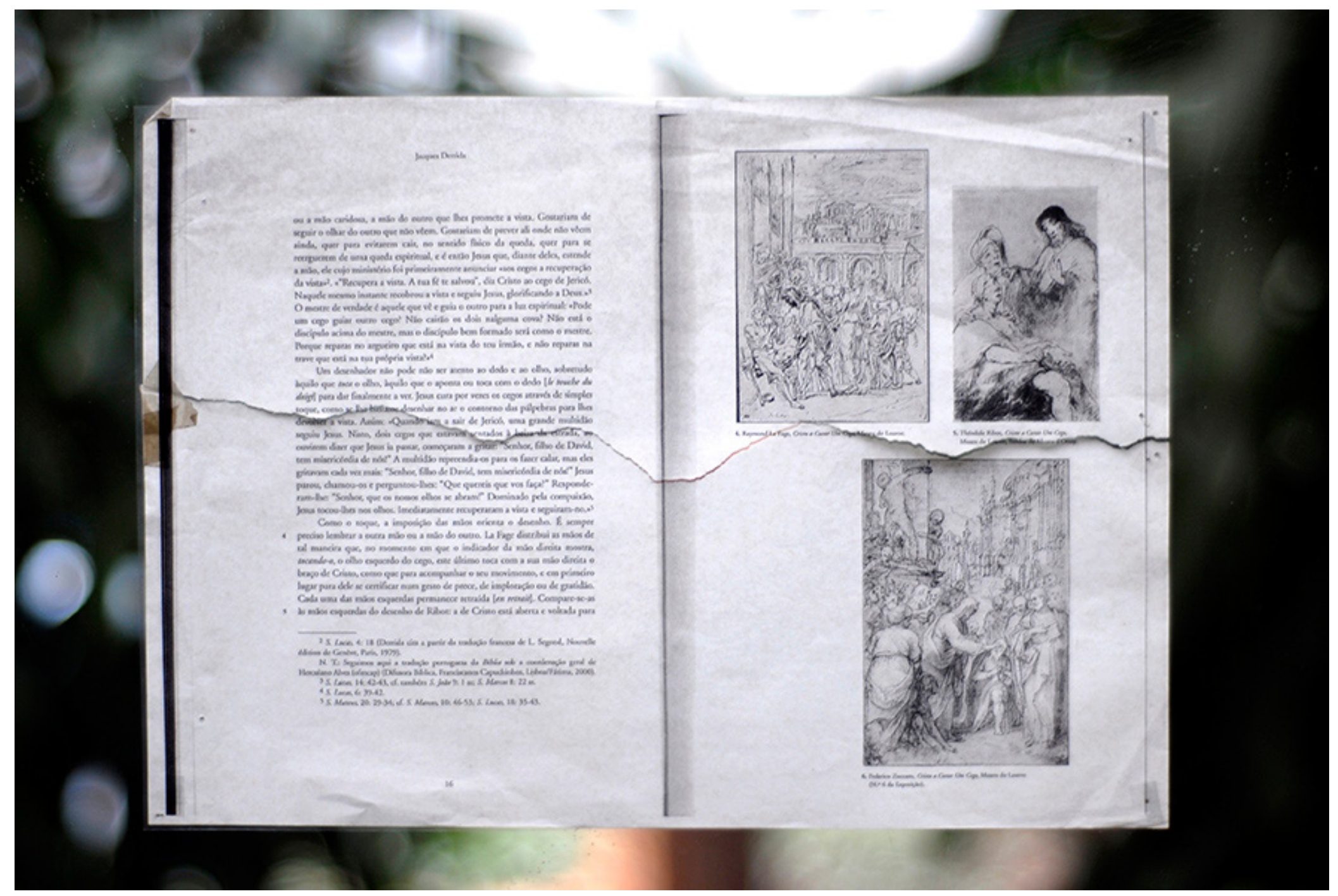

Figura 4: Gregório Soares, Pairos e outras ruínas para J.D., fotografia, xerox sobre transparência e desenho, 30 x 24 cm, 2014 . 


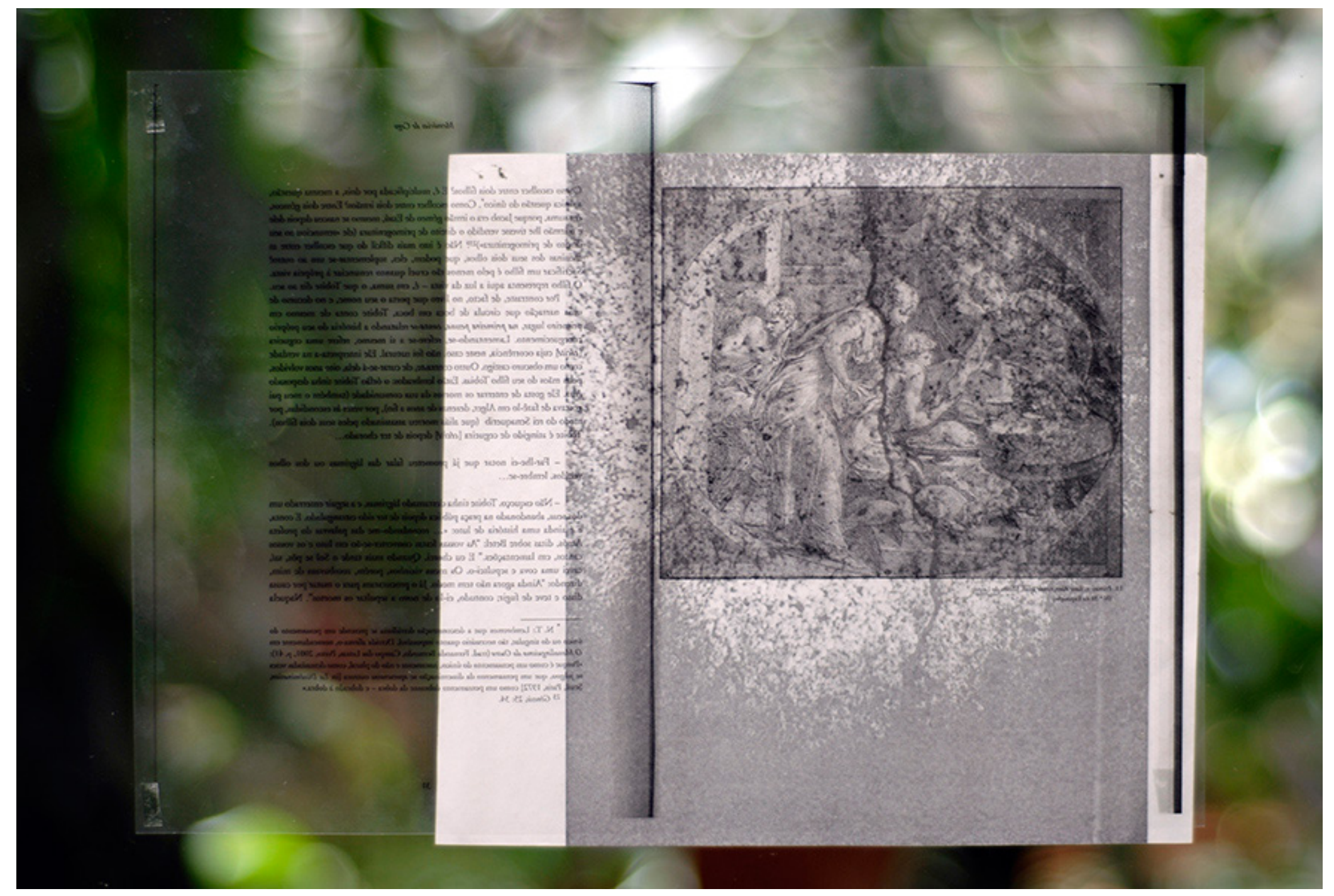

Figura 5: Gregório Soares, Pairos e outras ruínas para J.D., fotografia, xerox sobre transparência e desenho, 30 x 24 cm, 2014 . 


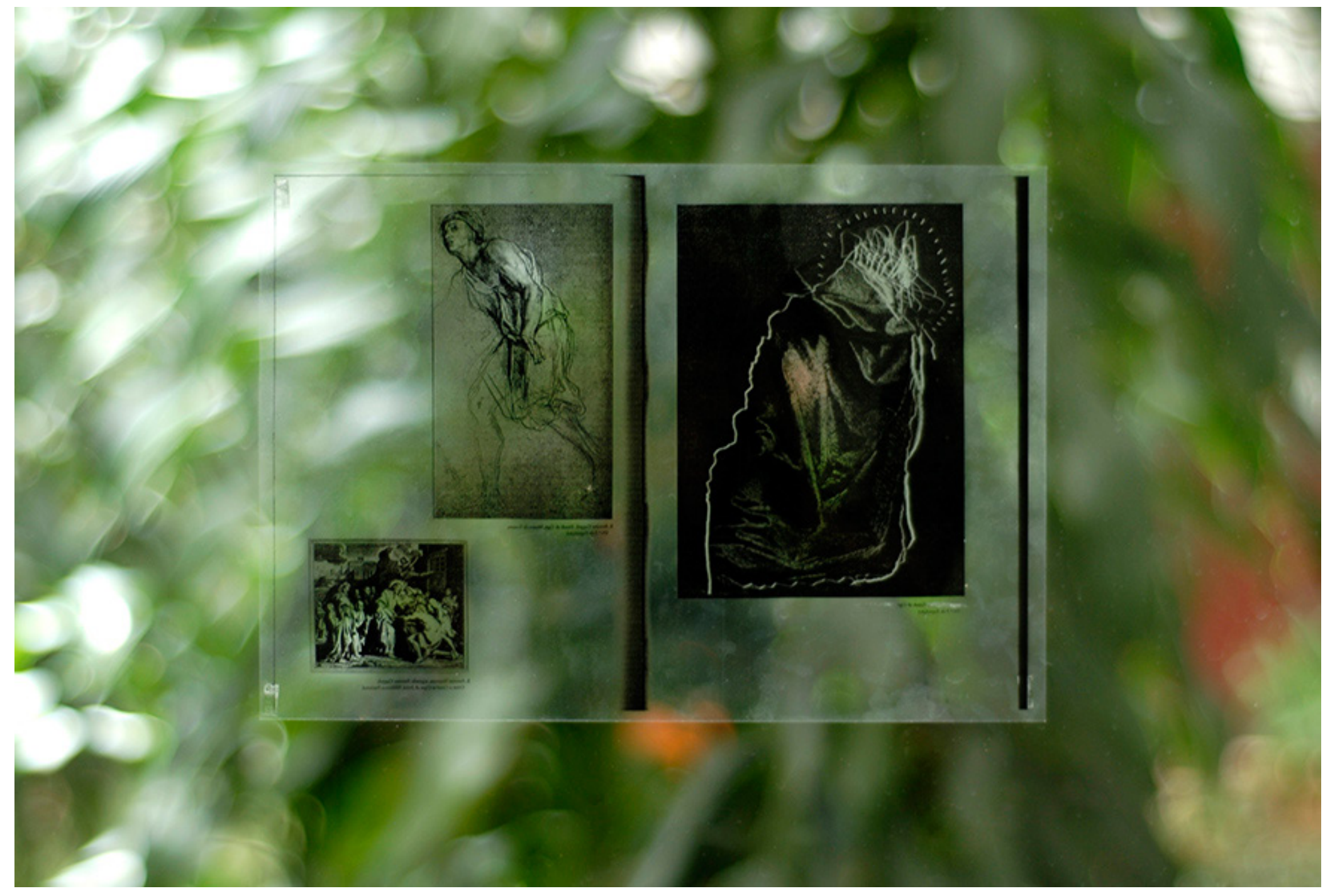

Figura 6: Gregório Soares, Pairos e outras ruínas para J.D., fotografia xerox sobre transparência e desenho, 30 x 24 cm, 2014 . 
1.1 excrivisuras, escrever o ver:

um desenho para os limiares da imagem-escrita

Tudo que você pode projetar como expressivo em termos de desenho - ideias, metáforas, emoções, linguagens estruturais - resulta de um ato de fazer. O desenho é um verbo.

Richard Serra

A própria teoria é uma prática, tanto quanto seu objeto. Ela não é mais abstrata que seu objeto. É uma prática de conceitos, e é preciso julgá-la em função de outras práticas nas quais interfere.

Gilles Deleuze, Cinéma 1 
texttexttext texttexttext textrexttext text tiext texttextrext texttextiext texttextrext

\section{ez}

Figura 7: Timm Ulrichs, Text, s/d.. 
Para começar com uma questão que é fundamental para qualquer escritor (pragmático ou poeta), pergunto-me o que pode estar atrás da pergunta: “como se pode escrever?"18. Esta é uma dupla questão e sei que quando começo a dizerescrever "como se...", trata-se já de uma pergunta-escrita. Escrevo para perguntar, no entanto, pressuponho que a pergunta vem antes da escrita, ela precisa estar em algum lugar, no pensamento talvez. Portanto, está ainda fora do gesto, antes de ser escrita. Tem-se que quando escrevemos a pergunta "como se pode escrever?", inicia-se uma resposta pois a pergunta já é feita escrevendo. Neste caso, há uma coincidência entre o pensamento e o que se quer escrever, assim, o pensamento como que se estende de forma correspondente para o ato da escrita.

Se estamos de acordo com essa correspondência exata entre o pensamento e a escrita, temos que a pergunta seria apenas de caráter retórico se não estivesse em jogo, na verdade, o próximo passo, o que se escreverá, a sucessão da escrita. "Como se pode escrever?" é uma pergunta, então, por meio da própria escrita mas que tenta responder o que está para fora dela. E que, para contradizer o acordo anterior, o pensamento não consegue pré-ver, antecipar, ele, de fato, não o sabe e precisa escrever ao menos para tentar começar uma resposta. É uma pergunta que nasce do silêncio e visa uma experiência, uma resposta, que surpreenda o próprio escrevente, se feita dentro do caráter poético.

\footnotetext{
${ }^{18}$ Esta pergunta foi feita por muitos mas é essencialmente reconhecida na "voz" de Francis Ponge, no
} seu famoso ensaio My creative method, em Ponge, F. Métodos. 1997, p. 36. 
Ou seja, é uma pergunta, mesmo que se não escrita, para ser feita, mora em algum lugar, murmurante, escuro, como sabemos, silencioso, não gera ruído, senão inscrito, descrito, gesticulado, enfim, colocada para fora, ex-ternada.

A partir do primeiro gesto, então, qualquer um que seja possível ser visto, menor que for, começa-se o risco da pergunta-resposta-escrita-imagem, o risco da responsabilidade de dar a ver. $\mathrm{O}$ ato da escrita (logo, a escritura) é, deste modo, por pressuposto, aquele que busca mostrar, demonstrar, dar à vista, tornar visível, pôr para fora. Todo ato de escrever, portanto, visa a visão, é para se escre-ver. Uma inscrição passível da vista: eis uma imagem da palavra: toda escrita é imagem. No entanto, o que se vê na imagem-escrita? O que ela apresenta?

Este gesto inaugural, de iniciação à qualquer expressão, revelação, manifestação etc., introduz junto dele a situação complexa que a filosofia, a psicanálise, a literatura e as artes, às suas maneiras, tratam quanto ao saber e ao não-saber, ao pensável e ao impensável, ao representável e ao irrepresentável, ou seja, quanto à questão da presença e da ausência na matéria do pensamento.

É certo que tal relação, entre a imagem e a escrita, esboçada nesta introdução um tanto espontânea e intuitiva, é tão longa quanto a história do conhecimento e não cabe aqui fazer uma retomada de todas as referências que a ela se fizeram, seria impossível. O objetivo deste capítulo é verificar e propor sua situação no contexto de certas manifestações "poéticas contemporâneas" e, de algum modo, relatar como ela se insere na elaboração dos meus trabalhos, incluindo este próprio 
(dissertativo), que "objoga"19 com a im/possibilidade de pensar um desenho (ou um desígnio) discursivo para o silêncio, o limiar das palavras-imagens.

Esta proposição pode ser sugerida, de algum modo simples, no diagrama ${ }^{20}$ ou esquema ${ }^{21}$ abaixo:

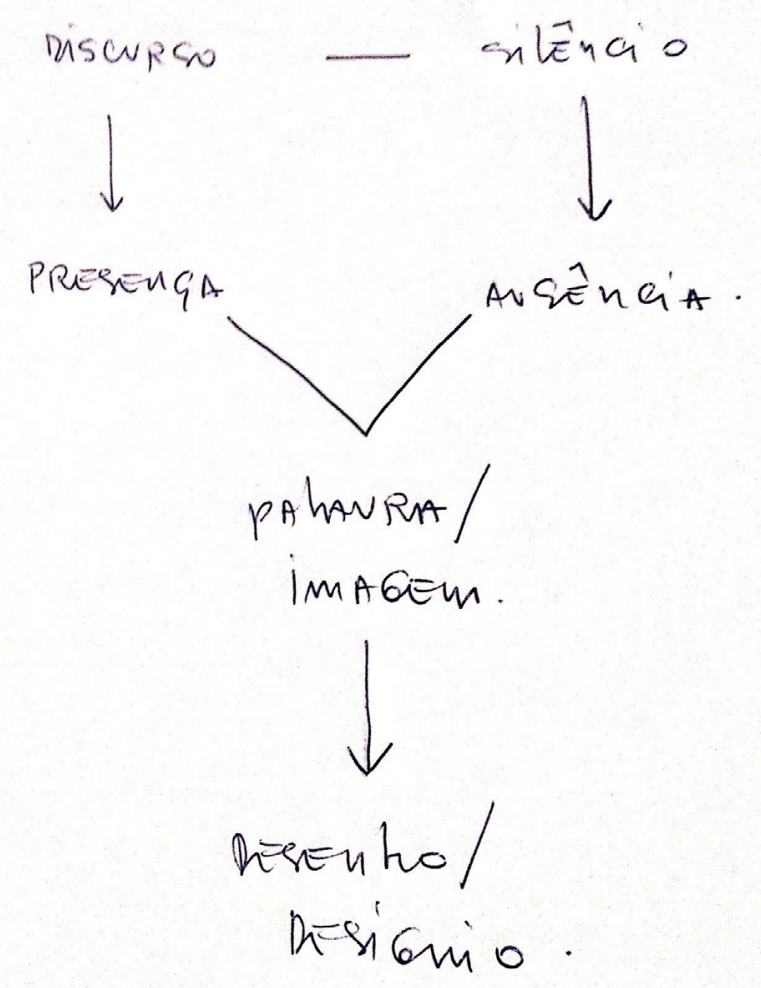

${ }^{19}$ No sentido dado por Francis Ponge para a palavra francesa "objeu" ("objogo": objeto + jogo).

${ }^{20}$ Diagrama: dupla ("di-") grafia: organização visual do verbal.

${ }^{21}$ Do latim schema, do grego skhema, "forma, figura". 
Para esta proposta de discussão é preciso esclarecer o que estou compreendendo como desenho e a sua relação, análoga ou não, com a escrita, o pensamento (ou a reflexão) e, por fim, com um (e o meu "próprio") fazer poético/ artístico $^{22}$ e/ou retórico.

Para propor um pensamento que aborde a questão do desenho, ou o desenho como questão, é preciso perguntar o que é possível desenhar sobre o desenho; quero dizer: escrever-dizer sobre o desenho. Ou o que se passa quando se diz que se quer dizer ou falar sobre o desenho? O que é possível, de outro modo, perguntar ao desenho, sabendo que não se pode esperar dele uma resposta, tão somente, sobre ele mesmo, sendo apenas uma unidade de desenho, ou um conjunto, mas nunca todos os desenhos? Pensar sobre o que se passa já é pressupor não só que algo acontece, mas sobrevém, atravessa, corta e, sempre, algo se perde. Como, então, dar a ver, dizer, pela escritura, exatamente isso que se perde e tem como possibilidade algo comum do acontecimento do desenho, que, como nos propõe

22 Ao longo do texto não farei distinção entre uma abordagem "poética" ou "artística", estou compreendendo e propondo que elas se interseccionam ao limite, ao ponto de não serem possíveis de diferenciação.

${ }^{23}$ Estes hifens aparecerão ao longo da dissertação como sugestão de "respiros" para o leitor e para o próprio conteúdo do texto. 
Derrida (2012, p. 68), não pode ser previsto? Portanto, em uma pergunta inicial: o que se passa quando se fala sobre o acontecimento de um desenho?

Tal tarefa se impõe em prováveis sobreposições e aqui só poderá se configurar com os seguintes contornos, a saber: a linha do desenho, a linha da palavra desenho, os contornos do desenho, do pensamento e das palavras, e a fissura poética entre desenho e escritura.

Falar sobre um desenho, em princípio, é como não desenhar enquanto se fala dele. Mas de alguma maneira essa diferença pode não ser visível ou, ao menos, pode se turvar, sombrear, distanciar-se de tudo que é possível definir: traçar uma linha. Se pensarmos na genealogia da palavra "desígnio", por exemplo, proveniente do latim DESIGNARE, "marcar, traçar", assinalado pelo prefixo DE-, do que está "fora", mais -SIGNARE, "marcar, apontar", proveniente de SIGNUM, "sinal, marca", podemos ver, nessa composição, que se divide entre o conceito latino (de + signo) e variações possíveis de projetar, arrastar, extrair e traçar, mantendo ao mesmo tempo: o próprio traçamento, o contornar, como o caminho prático de um fazer; e projetar, conceber, nomear, em um sentido que se tende ao inverso, este ligado à mirada adiante, ao lançar-se, disso que está em jogo no cogito, no raciocínio; ambos sentidos das marcas, contidos na etimologia da palavra desenho, lidam com um comum reprimido no prefixo latino "DE-", este "fora", ex-terno, que vem antes, próprio do homem, poderíamos dizer, com Derrida, sobre a suplementaridade: "aquilo cuja possibilidade cumpre pensar antes e fora do homem" (Derrida, 1973, p. 297), mas que antes também já revela como o desenho é o que permanece de 
fora, nas bordas, na moldura ${ }^{24}$, no próprio do contorno.

A hipótese prevista aqui, se posso dizê-la, é supor que a mesma linha que traça, define e determina, tem a vontade, talvez a necessidade, de separar, no traçamento próprio, dentro da abstração, daquilo que era antes o mesmo; ou seja, tem como função moldurar um discurso, teórico, textual, arrisco dizer conceitual, sobre o saber de um fazer no mundo. Assim, quando se fala em desenho, torna-se urgente desenhar sobre este desenho, traçar sua própria linha, a cada vez. Pois ao se falar em desenho, pode-se dizer do dito, do que é possível dizer, da própria palavra lançada, invisível, ou sobre o acontecimento do traço, enquanto marca em movimento, no gesto visível.

O desenho, pode-se dizer, é alguma coisa de um pressuposto, de tudo aquilo que vem antes, no próprio do projeto, do esboço, de um intuito, no pensamento na condição de um movimento prévio de qualquer feitura, de qualquer vir-a-ser. No entanto, no movimento de sua experiência, é impossível de ser pré-visto (de se ver antes). $O$ desenhista, perante essa imprevisibilidade ou essa impossibilidade de ver antes, desenha o impossível, por urgência. Sobre este ponto de vista, Derrida, nos diz-creve:

\footnotetext{
${ }^{24}$ Derrida discute a questão da moldura por meio do termo Parergon, sobre a questão da presença
} da verdade a partir de um "dentro/fora", no trabalho De la vérité en peiture, 1978. 
A experiência do acontecimento é uma experiência passiva, rumo à qual, e eu diria contra a qual, acontece o que não pode ser predito; é próprio do conceito de acontecimento que ele venha sobre nós de maneira absolutamente surpreendente. [...] Que relação pode ter o desenho com o que acontece? O desenhista é alguém que vê vir, que pré-desenha, que trabalha o traço, mas no momento em que isso traça, o movimento em que o desenho inventa, em que ele se inventa, é um momento em que o desenhista é de algum modo cego, em que ele não vê, ele não vê vir, ele é surpreendido pelo próprio traço [...]. Em todo desenho digno desse nome, naquilo que faz o traçamento de um desenho, um movimento resta absolutamente secreto (Derrida, 2012, p. 70-88).

Assim, a experiência do desenho, quando do registro de uma paisagem, de um retrato ou de um pensamento mesmo, está sempre diante dessa dupla impossibilidade da diferença, ou mesmo, suponho, desse quiasma, por um lado, óptico, por outro lado, retórico, a saber: a da própria impossibilidade de se saber ver o desenho que vem e da possibilidade de abertura do saber de todo desenho em seu movimento; até a própria aporia daí suscitada e de seu gesto poético, na diferença mesma entre o signo falado e o escrito, quando coloca o problema da representação já no extremo. Todo problema, por si, é um extremo, é uma linhalimite; se quisermos, é um problema de contorno. Assim, como se pode lidar com um problema extremo, de contorno, portanto? Seria preciso continuar a questão 
do atravessamento, sobre o corte como causa de todo desenho, para então trazer o que Derrida propõe como pictograma, "para designar essa obra na qual a pintura a cor, mesmo que seja a cor preta -, o desenho e a escritura não toleram nenhuma parede divisora, nem a das artes nem a dos gêneros, nem a dos suportes nem a das substâncias" (Derrida, 1998, p. 46-47). O que essa suposição impõe ao pensamento teórico? O que ela traça?

É urgente o gesto do traço, como princípio do atravessamento. Poderia supô-lo ainda como intruso ${ }^{25}$. Vale lembrar a passagem em que Jean-Luc Nancy, em seu texto Apertura dell'aporia, diz sobre a palavra "greffe" (enxerto) que "designava antes o estilete de escrever; escrever se diz em grego graphien, graphô. Estilete para escrever, mas que é antes destinado a desenhar, a traçar, à ação de griffer (arranhar), de grifar, de riscar, de marcar (...)" (Nancy, 2014, p. 18).

No entanto, para retornar à questão do que não se pode ver (do invisível), gostaria de trazer outro pensamento sobre o desenho. Trata-se de uma das poucas passagens em que Leonardo da Vinci aborda sobre o assunto, em seu longo tratado sobre a pintura. Leonardo intitula seu parágrafo (W. 19115a) sobre o desenho da seguinte forma: "Definição sobre o ser da linha", permitam-me citá-lo:

25 Para lembrar o tema do colóquio Pensamento intruso: Jean-Luc Nancy e Jacques Derrida, realizado em 2013, na Universidade de Brasília, e suas respectivas contribuições dedicadas ao esforço de pensar a "responsabilidade pelo sentido" e por um "enxerto intrusivo" do pensamento. 
A linha não conhece em si mesma matéria ou substância e, assim, mais deveríamos tê-la por coisa espiritual do que por substância, pois, em atenção a sua natureza, não ocupa lugar. Por isso, podemos imaginar que a intersecção de infinitas linhas se realiza em um ponto que carece de dimensões e cuja espessura (se assim podemos chamá-la) é igual à de uma só linha (Vinci, 2000, p. 138).

Uma das sugestões que se pode retirar desta passagem é o esforço de Leonardo em propor aos pintores sua identificação com uma "forma exata", que estaria contida no contorno dos corpos, mas que pode não ser visível, ou que continha (ou contém), em suas palavras, uma "linha de uma espessura invisível". Ora, o que seria uma linha de espessura invisível? Daniel Arasse, em um belo texto sobre o desenho em Leonardo da Vinci, nos propõe a formulação de uma dupla questão, fundamental, a respeito dessa linha: “De que ordem é a 'verdade' do contorno, já que é invisível na realidade? De que natureza pode ser essa forma, ao mesmo tempo exata e invisível?" (Arasse, 2006, p. 60).

É notória a contribuição de Leonardo às ciências de caráter descritivo da Renascença, por meio do exercício da linha do desenho. O texto de Daniel Arasse, no entanto, evidencia como, por meio das propostas de "demonstrações" rigorosas, "exatas" nos desenhos de Leonardo, ele, em algum momento, "não resistiu ao desejo de representar 'cientificamente' o que não tinha visto e que lhe era até impossível ver 'na realidade'" (2006, p. 64). O que Leonardo percorre, através do 
que pode se chamar de "componimento inculto", é que existe uma "relação íntima" entre a "atividade do olhar (...), o ato gráfico e a revelação de uma forma", na qual o desenho "não faz apenas chegar à inteligibilidade o real olhado; ele dá figura a uma configuração que estrutura e informa o olhar no processo de interrogar as aparências". Segundo Arasse ainda, a eficácia demonstrativa da linha gráfica "se deve precisamente ao fato de ela colocar diante dos olhos o que não é visível na realidade", portanto, por isso mesmo, "a 'demonstração' que propõe o desenho científico é de ordem retórica e persuasiva" (2006, p. 69).

É preciso lembrar que, para Leonardo, o desenho era um caminho para se chegar à pintura, para se chegar à sua "ciência da pintura", exatamente onde o desenho não poderia chegar, no sfumato, na sombra, mas apenas antever, no invisível, na especificidade de seus contornos. De outro modo, é possível dizer que Leonardo chega a um conhecimento das coisas do mundo, pela esquematização, extraindo sua forma fixa, enquanto no desenho artístico faz aparecer um ritmo invisível das coisas visíveis no movimento do mundo.

Para apenas situar, o problema da invisibilidade é também fundamental para Jacques Derrida pensar o desenho, as artes do visível e suas implicações ao pensamento e à "verdade" filosófica, sobretudo a partir de Mémoires d'aveugle (1990). Mas, vale lembrar, muito antes, em De la grammatologie (1967), a questão do desenho, do rastro, do traço, para Derrida, já designaria "a diferença pura, a diacriticidade, o que faz com que alguma coisa possa se determinar por oposição a outra coisa: o intervalo, o espaçamento, o que separa" (Derrida, 2012, p. 166). Ou 
seja, são dessas percepções e identificações que Derrida cruza sua preocupação com o traço e a linha da escrita, com o traço e a linha "invisível" ou "cega" do desenho.

Na história da filosofia o problema conceitual sobre a "imagem" não é diferente, tanto ligada à ideia quanto ao sensível da criação a partir da visão e do desenho ${ }^{26}$. Marilena Chauí, no seu texto "Janela da alma, espelho do mundo", de 1988, relembra a importância da palavra "ver" para sua relação ao "conhecimento", a partir da reflexão sobre a "imagem":

Da raiz indo-européia weid, ver é olhar para tomar conhecimento e para ter conhecimento. Esse laço entre ver e conhecer, de um olhar que se tornou cognoscente e não apenas espectador desatento, é o que o verbo grego eidô exprime. Eidô - ver, observar, examinar, fazer ver, instruir, instruir-se, informar, informar-se, conhecer, saber - e, no latim, da mesma raiz, video - ver, olhar, perceber - e, viso - visar, ir olhar, ir ver, examinar, observar (...).

No entanto, se o ver fabricador buscar a semelhança no ato mesmo de ver, estará na eikasia (representação, crença, conjetura, comparação) e tentará fabricar o eikon (ícone, pintura, escultura, imagem, imagem refletida no espelho) a partir do eikô (ser semelhante, assemelhar-se, verossímil, provável) (Chauí, 1988, p. 35).

\footnotetext{
${ }^{26}$ Especificamente sobre o desenho, Marilena Chauí exemplifica a discussão em torno de Alberti,
} Descartes e Kant, no mesmo texto, 1988, nas páginas 56 e 57. 
Ou, ainda neste trecho:

Conhecer é clarear a vista, como se o saber permitisse, enfim, olhar. Clarear a vista é ensiná-la a ver os signos da escrita e da leitura, "para ver se ele não ficava cego". Ver é pensar pela mediação da linguagem. Aqui, olhos e palavras não são rivais. (1988, p. 36)

No contexto de uma atual (e anacrônica) História da Arte, por exemplo, e sua devida reflexão também filosófica, Georges Didi-Huberman em seu livro Diante da imagem ${ }^{27}$, no segundo capítulo, intitulado "A arte como Renascimento e a imortalidade do homem ideal", dedica-se a mostrar como o re-nascimento da arte, e a invenção de sua história, no século XVI, com Giorgio Vasari, é elaborada justamente a partir da compreensão do conceito de desenho, afim de "desenhar, com as Vidas, a moldura de um novo gênero de discurso, de escrita, e de conduzir o leitor às margens de uma nova era do saber sobre a arte" (DidiHuberman, 2013, p. 74). Ou seja, o próprio Vasari, enquanto artista (arquiteto e pintor), também escritor ${ }^{28}$, acreditado da função "histórica", empenhado em não permitir "o esquecimento dos nomes" e da arte de seu tempo, por meio do entrelaçamento da escrita ao desenho (enquanto imagem); ou melhor, da escrita das suas três "Artes do Desenho (Arti del disegno): Escultura, Arquitetura e Pintura".

${ }^{27}$ Título original: Devant l'image, 1990.

${ }^{28}$ Essa relação, vale sublinhar, entre tais atuações não são aqui por acaso e muito diz aos objetivos dessa dissertação: expor o processo daquele que produz imagens e escreve sobre elas. 
Neste sentido, o que se evidencia, e é para isto que Didi-Huberman alerta, é que Vasari reconhece e intersecciona também as capacidades de criação e invenção às metafísicas e retóricas do desenho: "palavra 'técnica' capaz de operar todas as conversões, todas as passagens" (p. 100), entre o fazer e o saber, entre o olho e a Ideia:

É uma palavra descritiva e uma palavra metafísica. É uma palavra técnica e uma palavra ideal. Aplica-se à mão do homem, mas também a sua fantasia imaginativa, e igualmente a seu inteletto (...). Procede do vocabulário de ateliê, no qual designa a forma obtida sobre um suporte pelo lápis de carvão ou pelo creiom do artista; designa também o esboço, a obra em gestação, o projeto, o esquema composicional ou o traçado das linhas de força. (...) O efeito visível, causa inteligível. E, sempre sob a autoridade da mesma palavra mágica, a forma produzida sobre o suporte tornar-se-á a forma dos filósofos, isto é, a ldea (isto é, a negação de todo suporte material) (2013, p. 105-106).

Um dos problemas, para Didi-Huberman, é que assim re-fundada a "Arte" e fundada a sua "História", à imagem e semelhança do discurso do disegno, ela mesma se "especifica", fecha-se e encerra-se nas bordas e na moldura de sua própria retórica, em sua própria constituição, em seu próprio objeto, em seus próprios "fins", tudo isso em oposição à "opacidade", à "abertura", aos limites e ao "destino" incerto e inseguro gerado pelas imagens. 


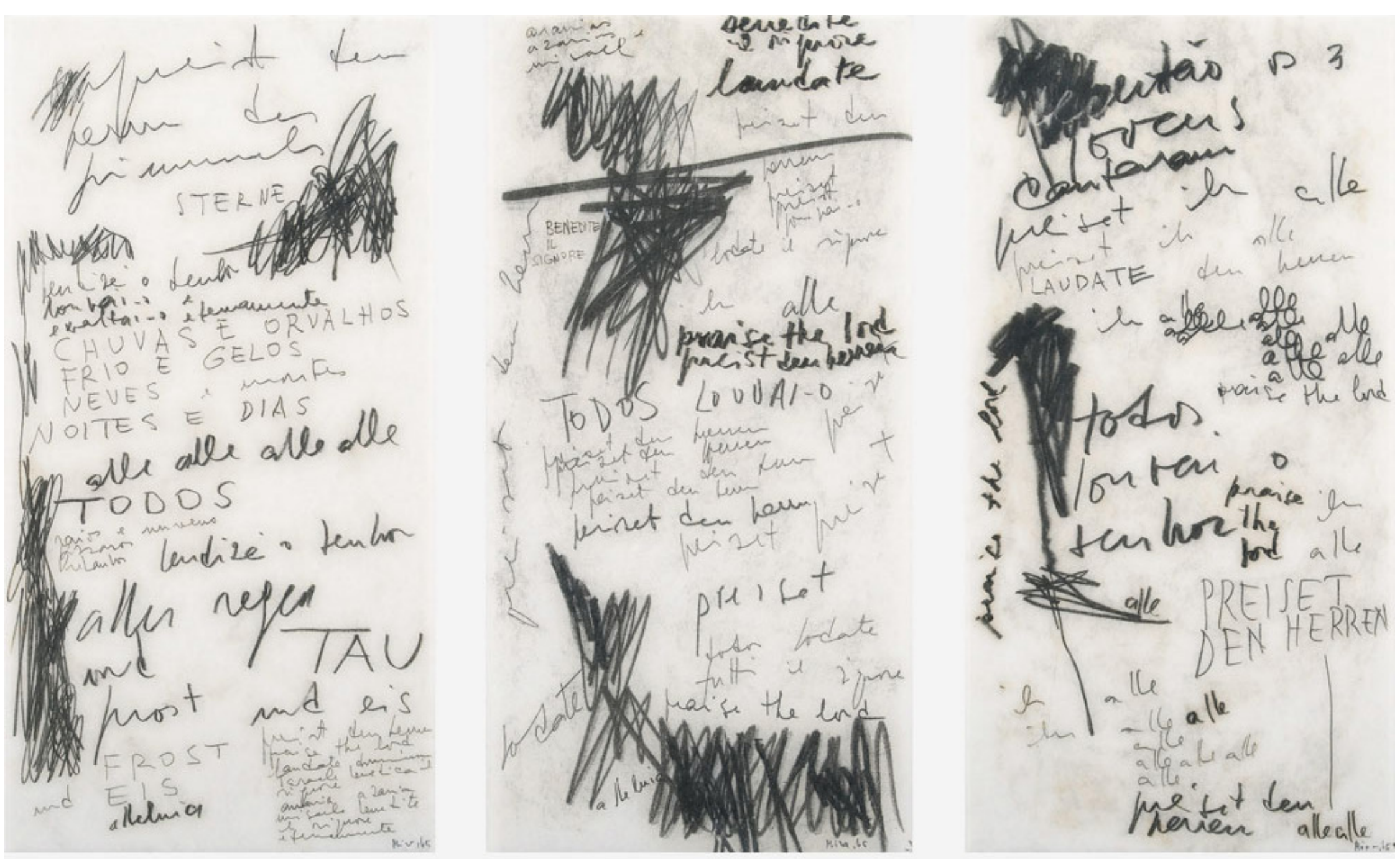

Figura 8: Mira Schendel, série Escritas, Monotipia, 1965, 46 × 23 cm (un.). 
De algum modo, a partir dessas reflexões sobre o desenho, a sugestão é de se pensar como a práxis de um desenhista, a priori, ou de um "artista visual" ou "plástico", em algum momento, se confunde, ou melhor, se intersecciona à práxis de um filósofo, também a priori. Insisto em marcar este a priori, pois no momento em que estes sujeitos, neste caso, da Vinci, Vasari e Derrida, estão empenhados no que Daniel Arasse denomina "fazer saber", por meio de um "saber fazer ver" (Arasse, 2006 , p. 61), ou seja, inquietos pela feitura do traço, quando eles designam, quando eles desenham, de alguma maneira "cegos" pela feitura, eles são, ao mesmo tempo, um só outro. Ou seja, paradoxalmente, são um só e diferentes, vinculados pela prática do desenho/desígnio, essa imagem ativa que é a um só tempo intelectual e imaginativa, pensativa e criativa.

É inegável que este lugar de encontro comum da diferença, aporético por excelência, é permeado pelas dificuldades impostas por suas especificidades textuais. Isto é, pelos seus distintos modos de lidar com a textura do discurso, com a narrativa, ou com uma ideia de estrutura do narrar que historicamente se confrontou como sendo uma função ora mais da imagem, ora mais da palavra. Assim, o que se estabelece, desde então, é que se trata de um problema de "representação" e suas funções conceituais e imaginativas. A larga tradição desse "confronto"(que 
não caberá aqui alongar) é privilegiadamente marcada por reflexões desde a antiguidade, com a máxima horaciana: Ut pictura poesis, passível de tantas interpretações diferentes, críticas e especulativas, em sua Arte Poética; até chegar a Lessing, que em 1766 publica seu famoso tratado Laokoon, ou os limites da pintura e da poesia, no qual se alterava a discussão entre as duas artes [poesia e pintura] para a questão das artes espaciais e artes temporais ${ }^{29}$, discussão esta que marca o período renascentista e, basicamente, influirá até o final do século XIX e retornará insistentemente ao longo do século $X X$, dos manifestos de vanguarda às práticas da Arte Contemporânea, inserida a partir das discussões da Arte Conceitual e nas discussões teóricas do estatuto da imagem em relação à Teoria e História da Arte; ou seja, dentro desse vasto e ao mesmo tempo estrito campo do "saber" da arte e suas possibilidades de manifestação, que são veiculados pela articulação das palavras e das imagens, ou por esta dupla via do conhecimento, que é possível dizer: sensível e conceitual.

Tal é o panorama conceitual e teórico que os artistas-escritores enfrentam nas poéticas contemporâneas, que reestabelece uma relação do "silêncio da imagem" com o que precisa quebrar o silêncio e ser dito (e escrito), ou "excrito" ("excrit"), para citar o neologismo cunhado por Jean-Luc Nancy, escrevendo sobre Georges Bataille, no qual se refere à um "escrever fora de si mesmo, escrever sempre e por definição o que não permite ser escrito: este é o objeto impossível da escrita. 
Por isso, escrever é escrever fora, ex-, excrever" (Nancy, 2013, p. 312).

É também em um sentido parecido o que Tania Rivera propõe no texto justamente chamado " $A$ excrita e o real", 2012, sobre a relação intensa (e ex-tensa) de Hélio Oiticica com a escrita. Para a autora, os textos do artista "não só são 'inventivos' - ou seja, produtos do mesmo estado de invenção que caracteriza seus objetos, proposições etc. - como a publicação é valorizada como meio legítimo de apresentação de sua obra" (Rivera, 2012, p. 84). E, da mesma forma, os títulos de seus trabalhos "devem, ao lado das categorias mais amplas criadas pelo artista, ser considerados como invenções ou como conceitos poéticos: metaesquemas, penetráveis, ninhos, bólides, o crelazer, o suprassensorial etc". Ou seja, toda sua obra deve ser considerada como uma "operação de linguagem" e "matéria poética". Construção esta que é também tributária à relação que Hélio Oiticica estabeleceu com os poetas concretos ${ }^{30}$, sobretudo, Haroldo de Campos, evidente nas estruturas verbais propositivas do artista, "cheia de neologismos, sinais gráficos como o travessão e recursos como caracteres em negrito ou maiúsculas, parênteses, sublinhado e setas, além do espaçamento ${ }^{31}$ das palavras na folha de papel” (p.86).

${ }^{30}$ Para um mergulho profundo nas relações entre Hélio Oiticica e suas referências poético-literárias, ver COELHO, Frederico. Livro ou livro-me. Os escritos babilônicos de Hélio Oiticica (1971-1978), Rio de Janeiro: EdUERJ, 2010.

${ }^{31}$ Com relação à questão do "espaçamento" poético, vale dizer que este é inaugurado na literatura por Stéphane Mallarmé, e seu poema "Um Lance de Dados" (do francês, "Un Coup de Dês"), de 1897. 
As operações na matéria da linguagem, em Hélio Oiticica, vai ainda além da relação gráfica ${ }^{32}$ palavra-suporte, e expande para as relações "palavras-objetos", "objetos-palavras" (da mesma forma ocorre com o desenho quando se expande para os objetos e para o espaço) e palavra-corpo. Portanto, suas formulações da linguagem passam a atingir o sujeito em relação ao espaço:

No espaço, no objeto e na linguagem pode surgir o sujeito - ou melhor, talvez o sujeito só esteja nos objetos de linguagem que configuram espaço, só apareça nesse convite, nessa armadilha, nessa arquitetura poética por eles construída (Rivera, 2012, p. 91).

Este sujeito evocado, provocado pela linguagem de Oiticica, é este que explora "o mais íntimo", que "aparece entre, fora" e "é neste sentido que a escrita de Hélio revira-se toda para fora, aponta para o que é externo a ela, é ex-crita. (...) Escrita que se retorce como uma fita de Moebius e se transforma em Parangolé" (p.94).

O que proponho aqui, então, como excrivisuras, e nos títulos ensaiados no início deste capítulo, é uma manipulação da linguagem na matéria-palavraimagem tal qual a que Hélio Oiticica apropriou e propôs com Parangolé:

\footnotetext{
${ }^{32}$ No sentido de uma poética visual e gráfica da palavra-imagem, remeto, como exemplo, às grandes
} obras de artistas tais como Cy Twombly, Mira Schendel e León Ferrari. 
uma palavra fora da palavra, excessiva, sem significado direto, silenciosa, mas que provoca espaçamento, movimento e profundidade. "Uma escrita da invenção, do cotidiano, do experimental. Um escrita, enfim, da diferença" (Coelho apud Rivera, 2012, p. 114), compreendendo que a diferença, da qual fala Frederico Coelho, é a que produz distância, pressupõe espaço, abre caminhos possíveis.

Tal escrita, de palavras-imagens, de modo a funcionar como uma tentativa do que propõe Marco Giannotti, em seu texto "A imagem escrita"; aos artistas, diz ele:

cabe fazer com que a pedra ou o pigmento falem a sua linguagem, tornando a matéria expressiva. É preciso criar através da escrita uma linguagem específica para esta atividade, uma linguagem capaz de descrever o embate do artista com a sua obra. Isso jamais poderá ser atingido nas artes plásticas sem uma linguagem poética (Giannotti, 2003, p. 104).

São estas questões que gostaria de levantar para apontar onde se encontram minhas dúvidas e pesquisas em relação ao "o que (e como) se pode escrever" sobre meu próprio trabalho, desde a utilização dos espaços institucionais do "título" até este dissertativo que se ensaia, que já são, a meu ver, em alguma medida, a junção 
entre desenho, escrita, pintura ${ }^{33}$ e pensamento, ou, para resumir, apenas poético, que é o mesmo que a busca pelo sentido poético, a feitura do sentido, sempre "por fazer", tal como Nancy também propõe, em seu texto "Fazer, a poesia"34: “'Poesia' não tem exatamente um sentido, mas, antes, o sentido do acesso a um sentido a cada vez ausente e adiado. O sentido de 'poesia' é um sentido sempre por fazer" (Nancy, 2013, p. 416). Ou mesmo, quebrando de vez o silêncio, em partes, criando outros silêncios: "Poesia é fazer tudo falar" (p.421).

É, assim, no ato da criação poética, que o silêncio se emaranha a uma textura de palavras-imagens, contornando um espaço, ex-terno, desenhando um emaranhado de linhas: margeando aquilo que é possível formular num dizer, mesmo que não pareça possível, é preciso correr o risco, o risco da palavra enquanto matéria, o risco tal qual aponta Italo Calvino, em "Aventura de um poeta":

(...) palavras e palavras, cerradas, embaralhadas umas por sobre as outras, sem espaço entre as linhas, até que pouco a pouco não se distinguiriam mais, era um emaranhado de que iam sumindo até as mínimas frestas brancas, e restava só o negro, o negro mais total, impenetrável, desesperado como um berro (Calvino, 2013 p. 116).

${ }^{33}$ Compreendendo tais práticas para além das categorias das linguagens artísticas tradicionais, e mais próximo de seus sentidos amplos e imbricados que tentei demonstrar.

${ }^{34}$ Do original em francês: "Faire, la poésie", in: Nancy, J.-L. Resistance de la poésie. Bordeaux: Éditions William Blake \& Co, 2004, p. 9-15. 


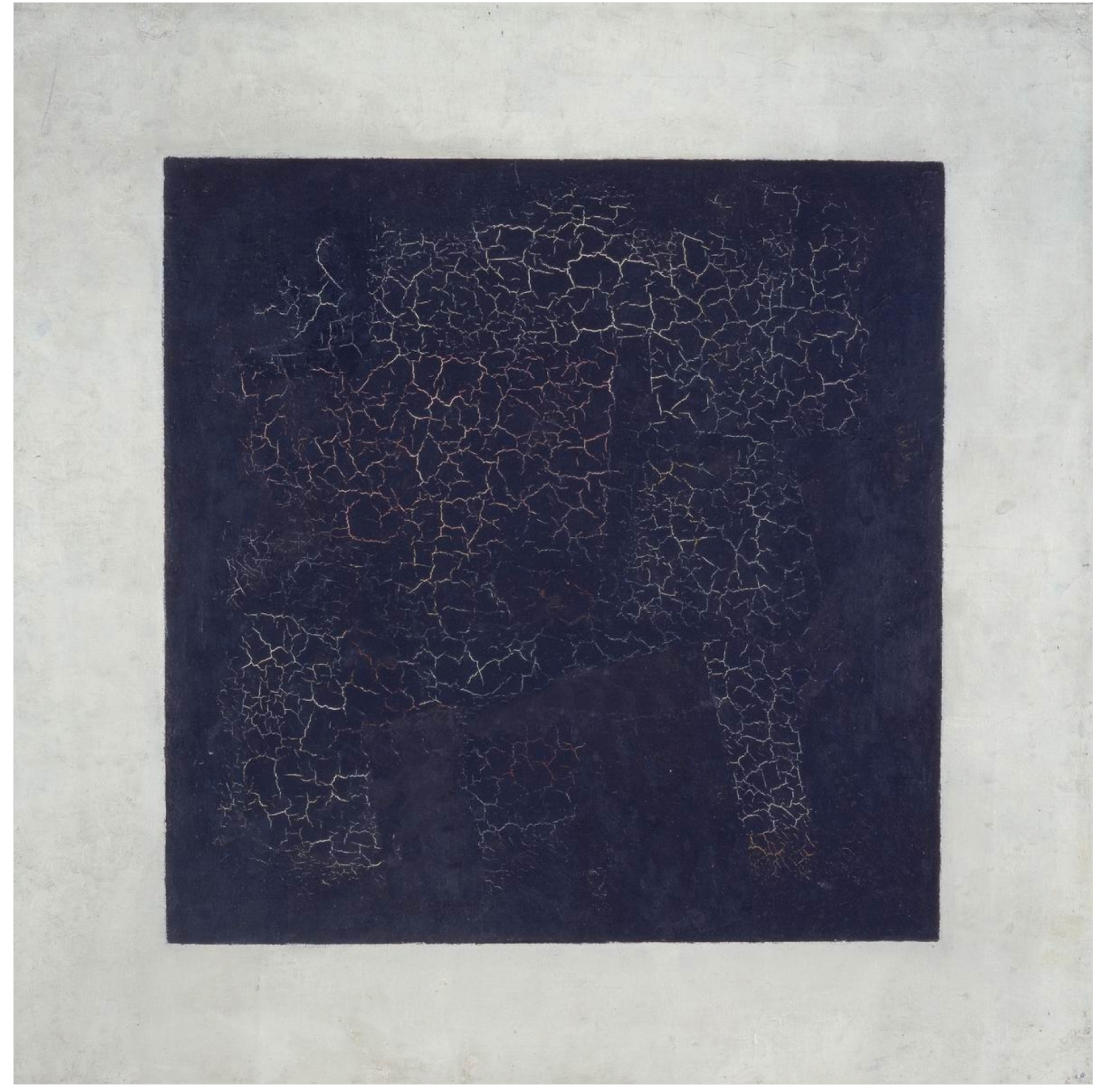

Figura 9: Kazimir Malevich, Black Square, óleo sobre tela de linho, 79,5 x 79,5 cm, 1915 . 
2 Triscar a ruína 

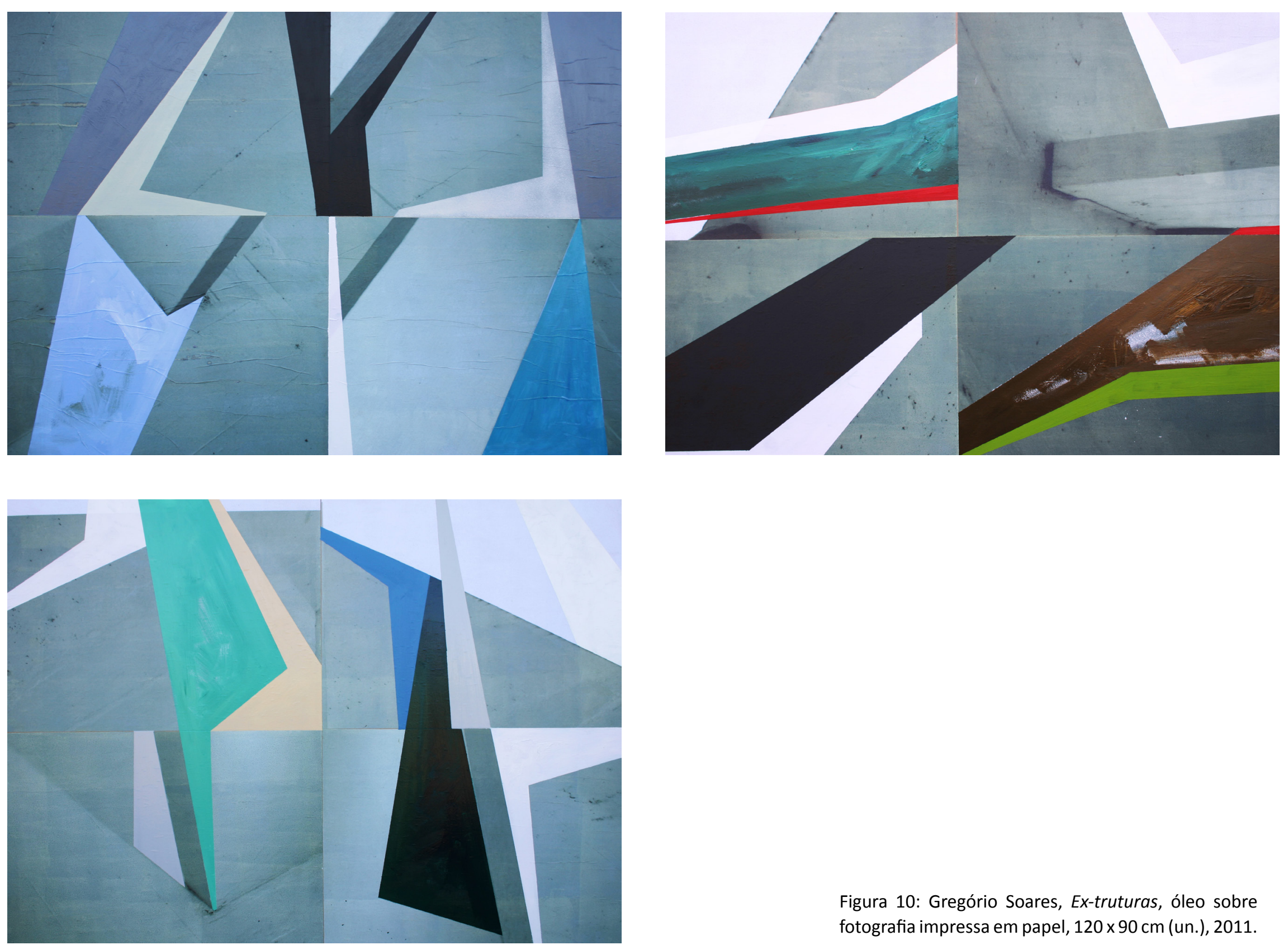

Figura 10: Gregório Soares, Ex-truturas, óleo sobre fotografia impressa em papel, $120 \times 90 \mathrm{~cm}$ (un.), 2011. 


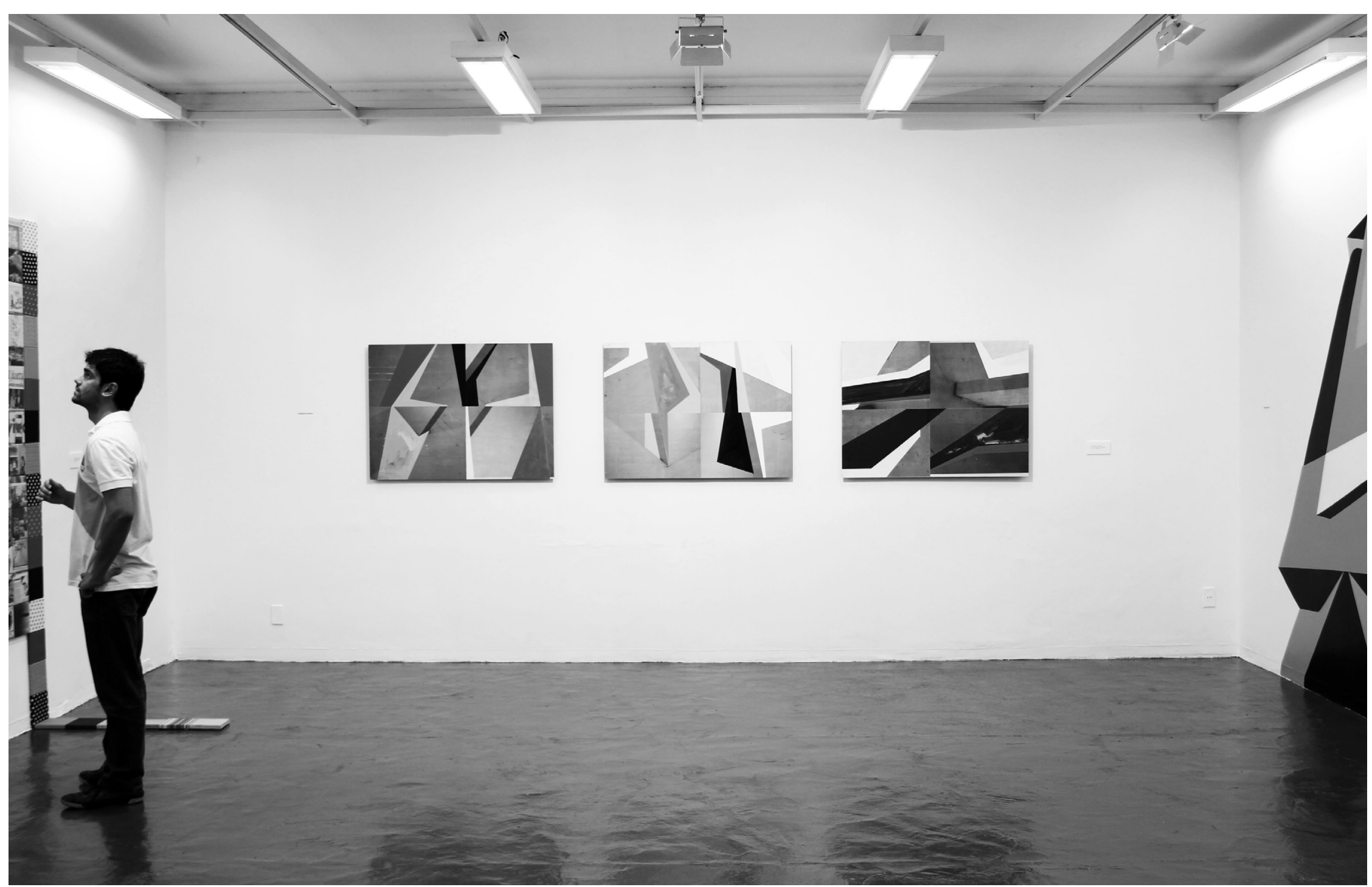

Figura 11: Gregório Soares, Ex-truturas (obra exposta), 17o Salão Anapolino de Arte, 2011. 


$$
\div
$$



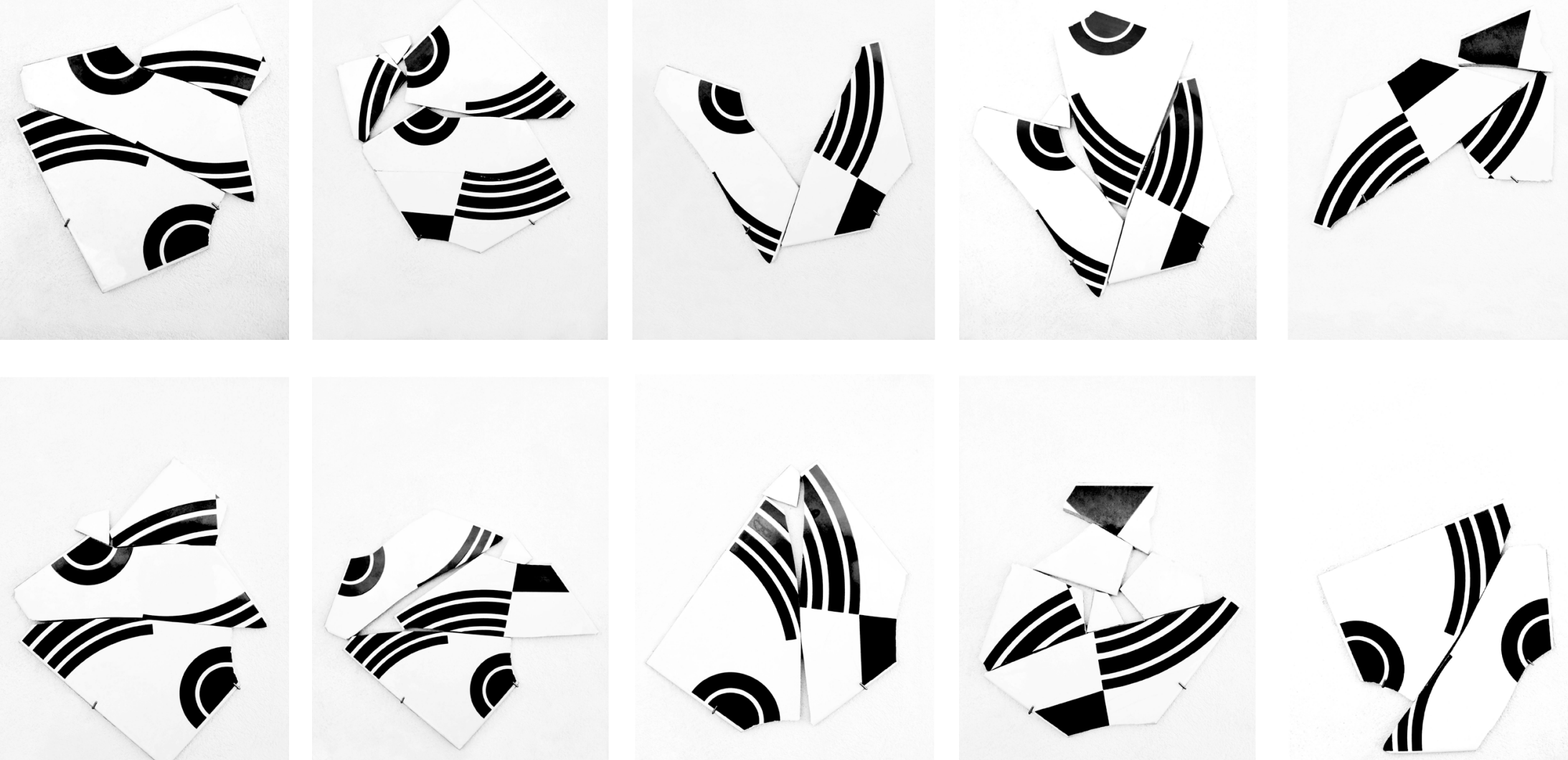

Figura 13: Gregório Soares, Autorretratos: estruturas equívocas, fotografia, $45 \times 32 \mathrm{~cm}$ (un.), 2011. 


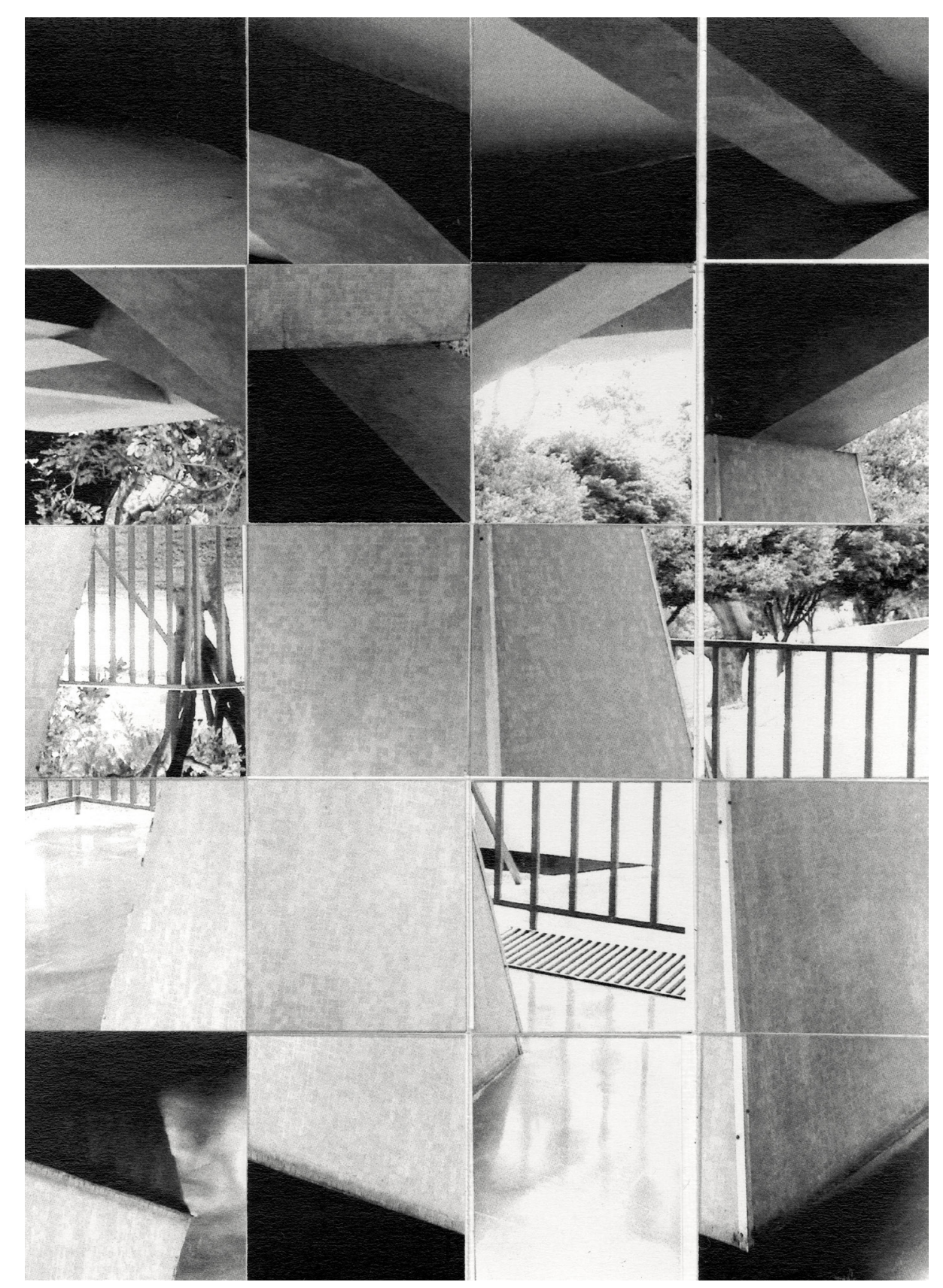

Figura 14: Gregório Soares, Pilotis: estruturas 

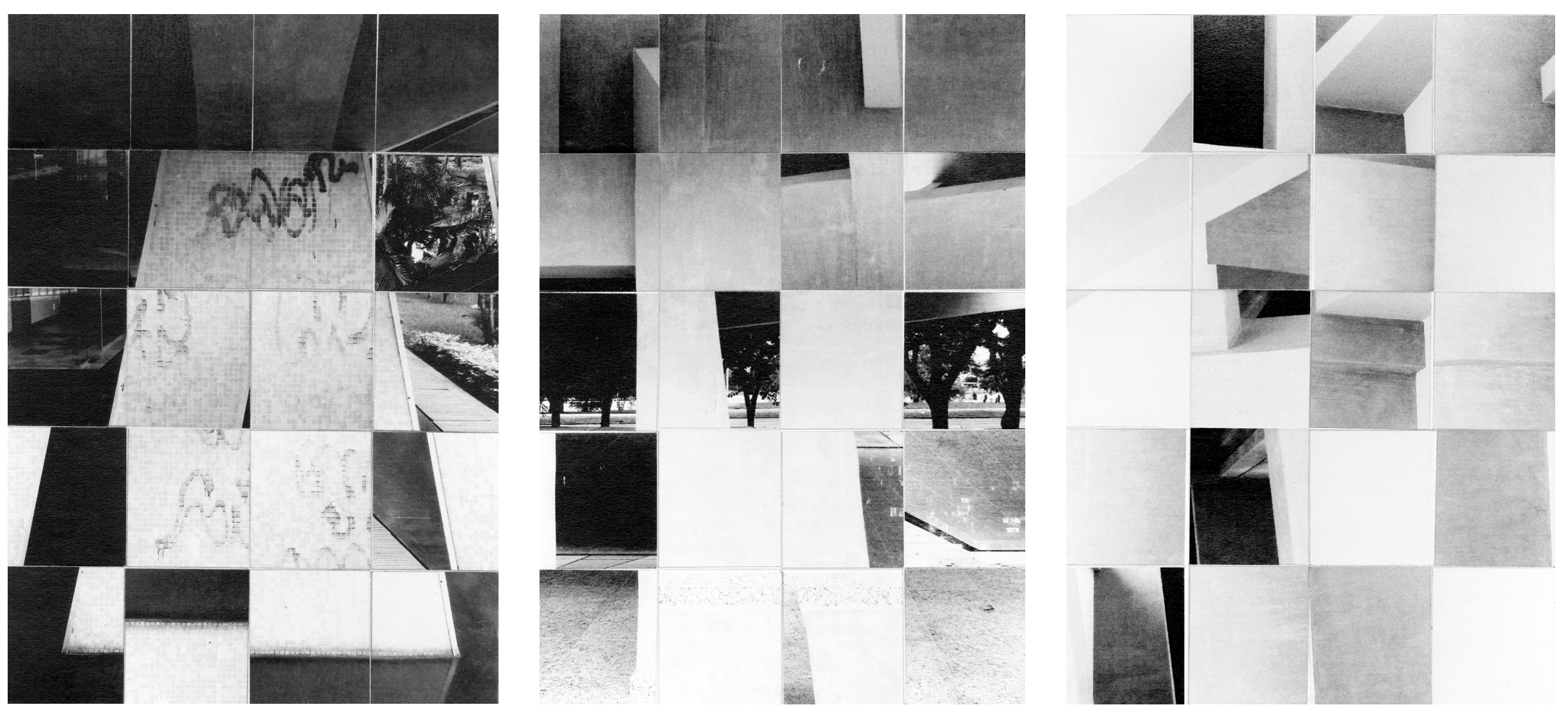

Figura 15: Gregório Soares, Pilotis: estruturas equívocas, foto-colagem, tríptico, $30 \times 25 \mathrm{~cm}$ (un.), 2011. 


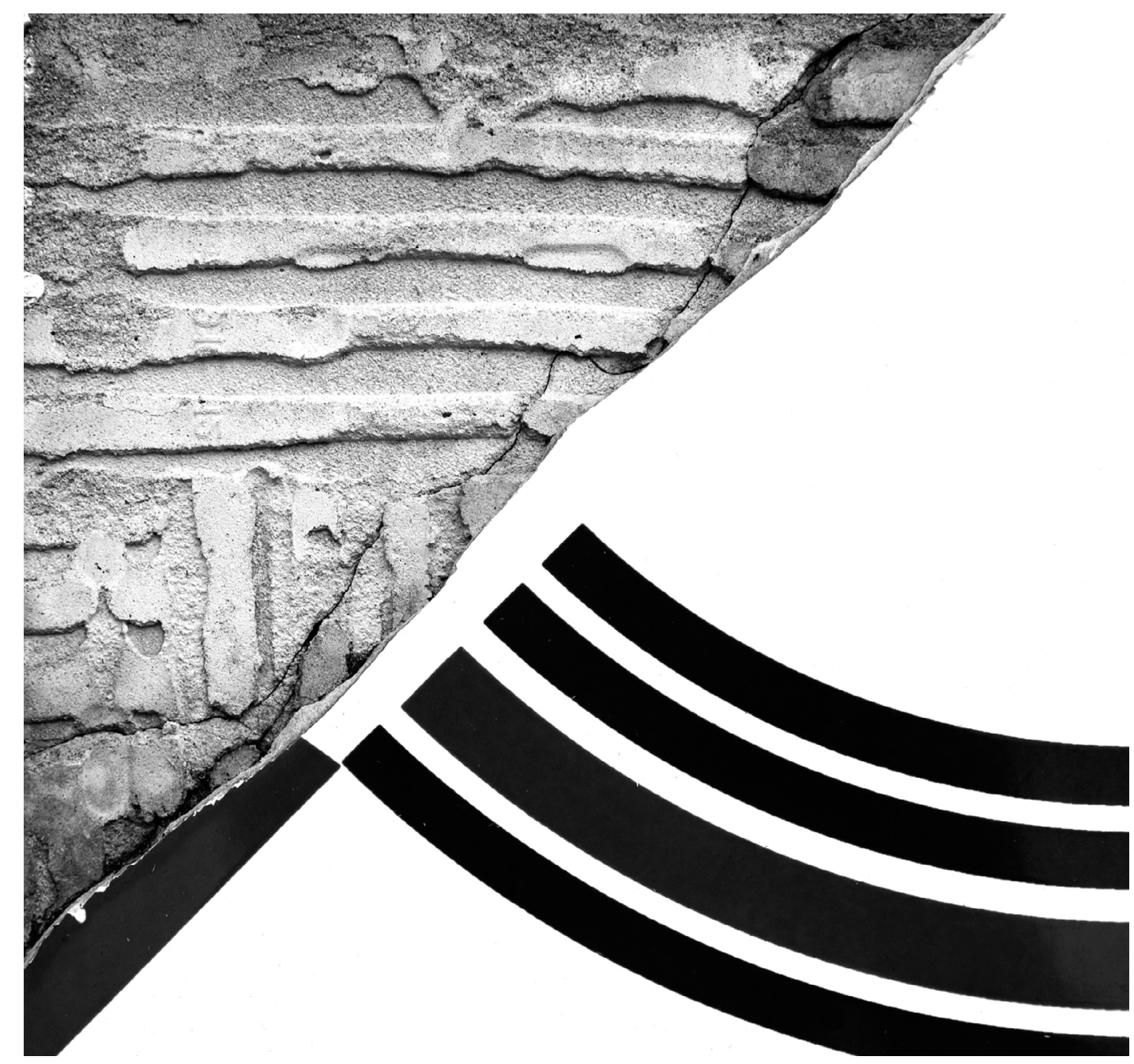

Figura 16: Gregório Soares, Fissuras: estruturas equívocas, fotografia, $50 \times 50 \mathrm{~cm}, 2012$. 


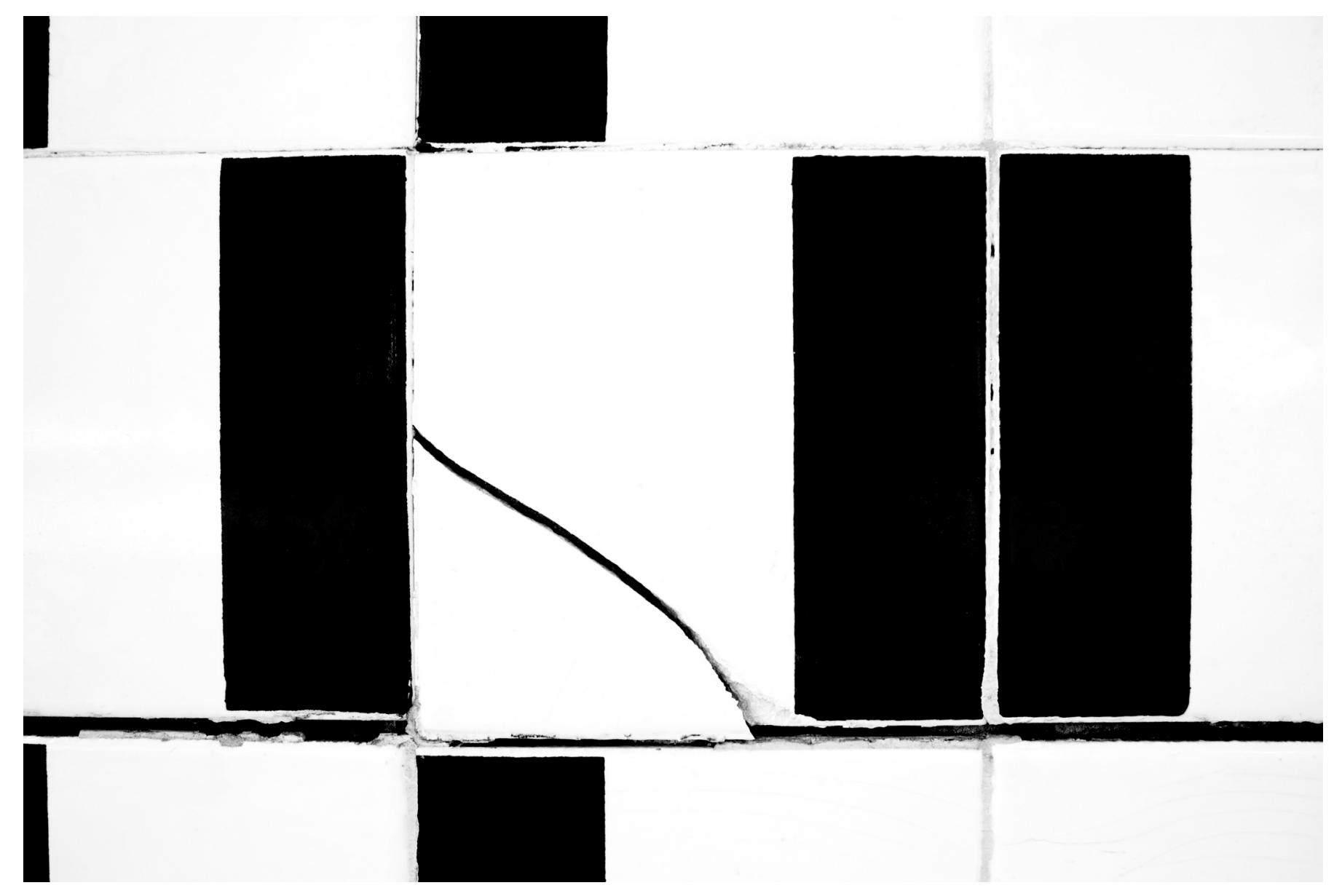

Figura 17: Gregório Soares, Fissuras: estruturas equívocas, fotografia, $50 \times 70 \mathrm{~cm}, 2012$. 


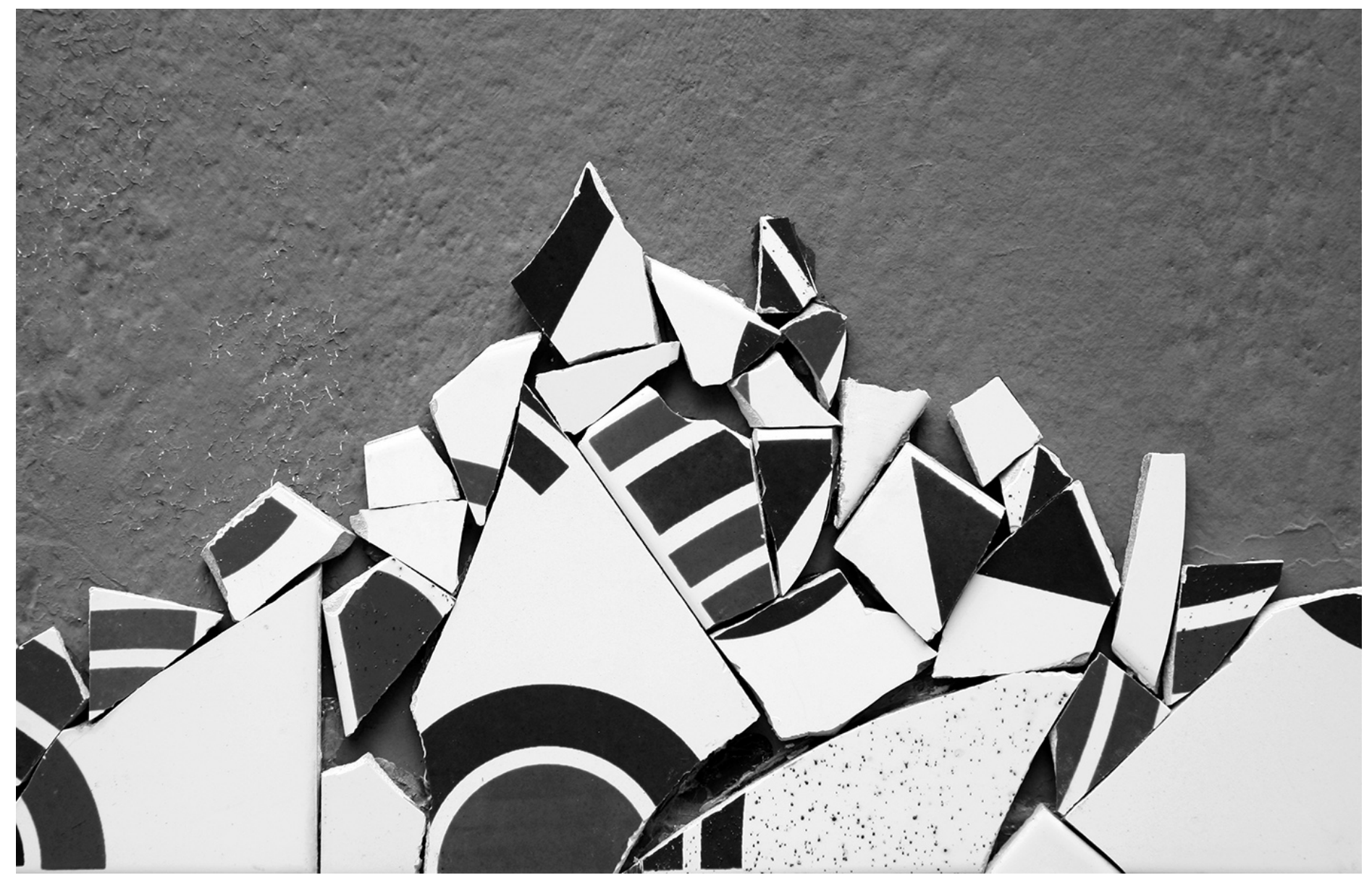

Figura 18: Gregório Soares, Paisagem tétrica Il: coleção de cacos (ou, rodapé), detalhe, mural/site-specific, .30 × 8 m, 2015 . 


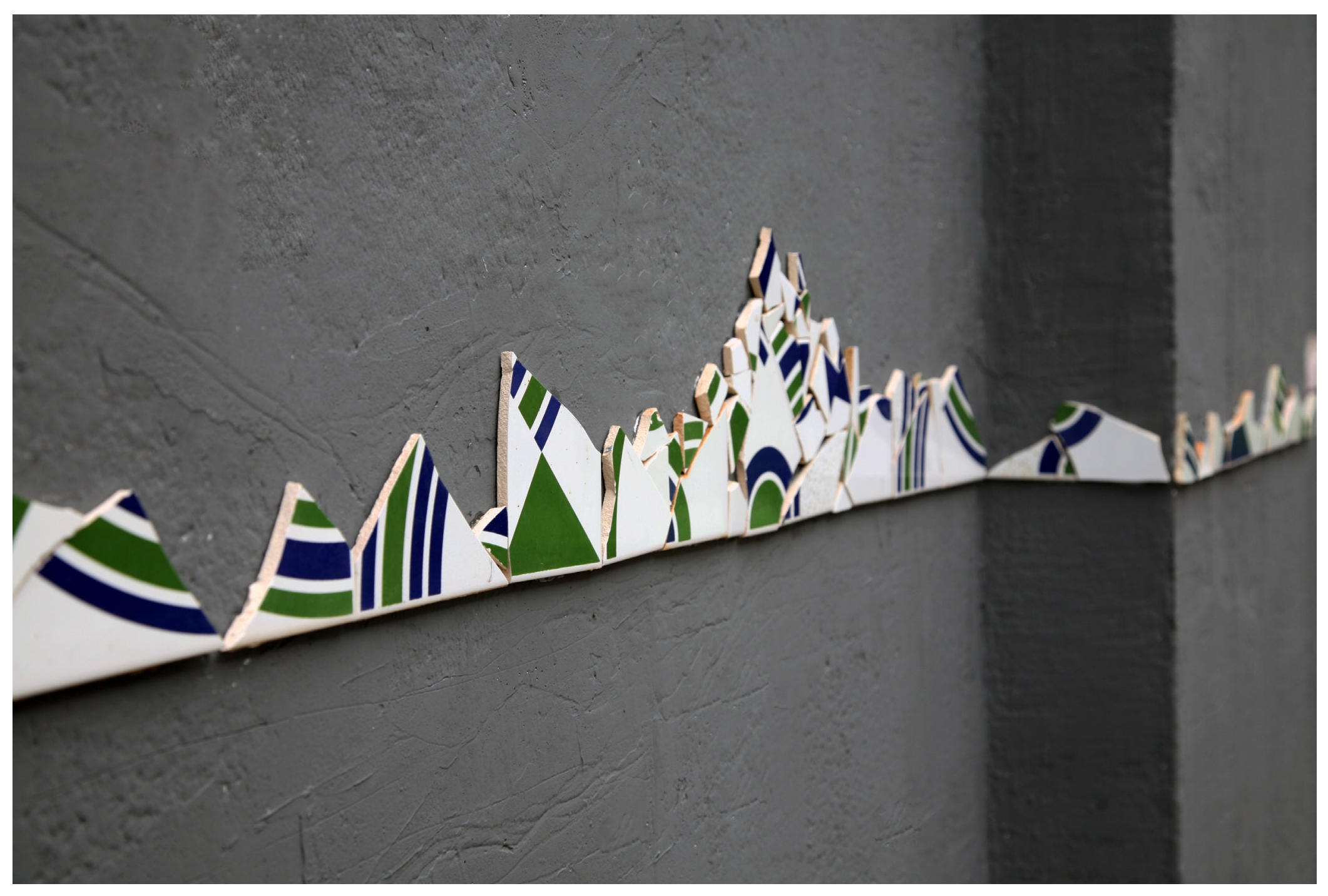

Figura 19: Gregório Soares, Paisagem tétrica II: coleção de cacos

(ou, rodapé), detalhe, mural/site-specific, .30 x 8 m, 2015 . 


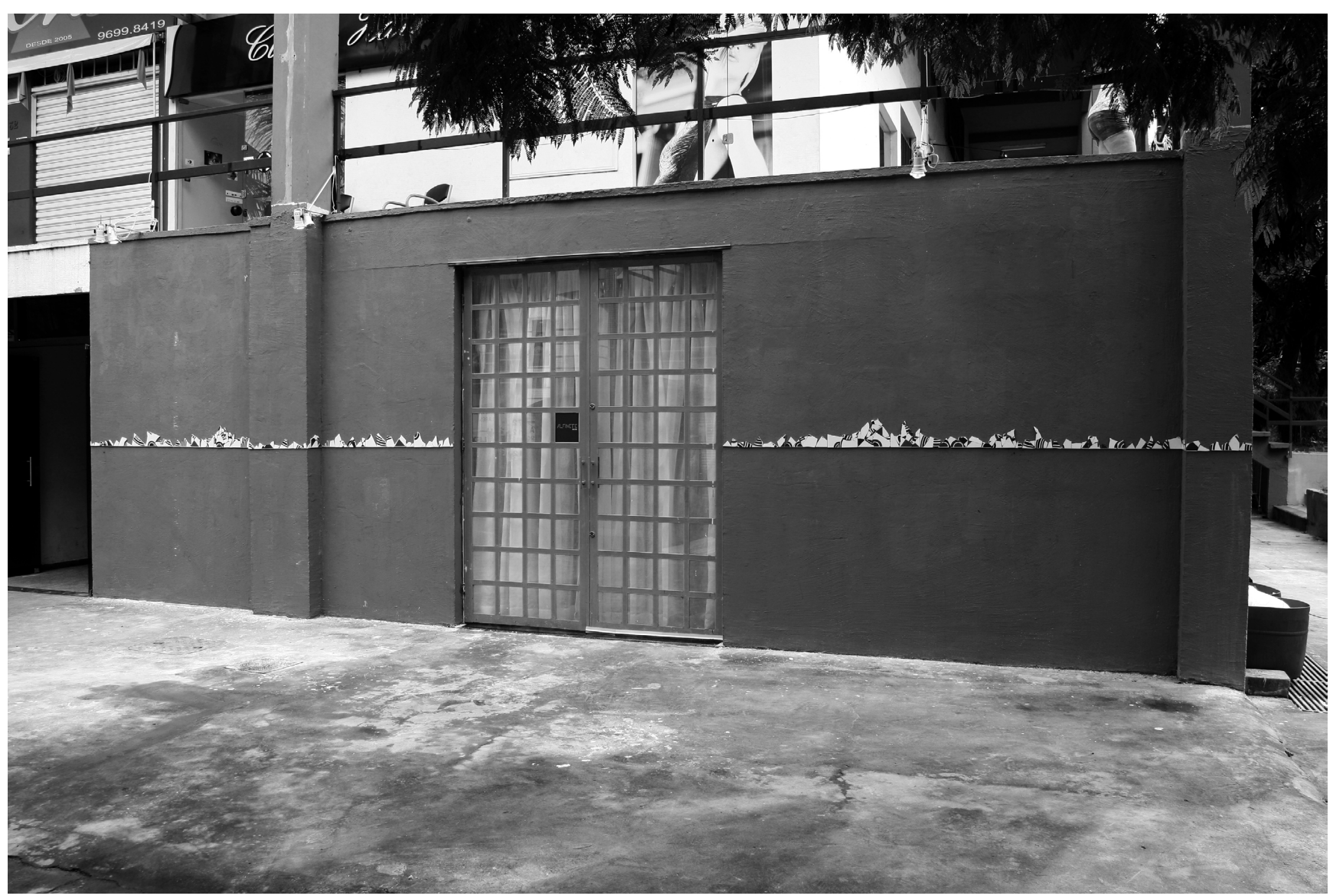

Figura 20: Gregório Soares, Paisagem tétrica II: coleção de cacos (ou, rodapé), mural/site-specific, . $30 \times 8$ m, 2015 . 


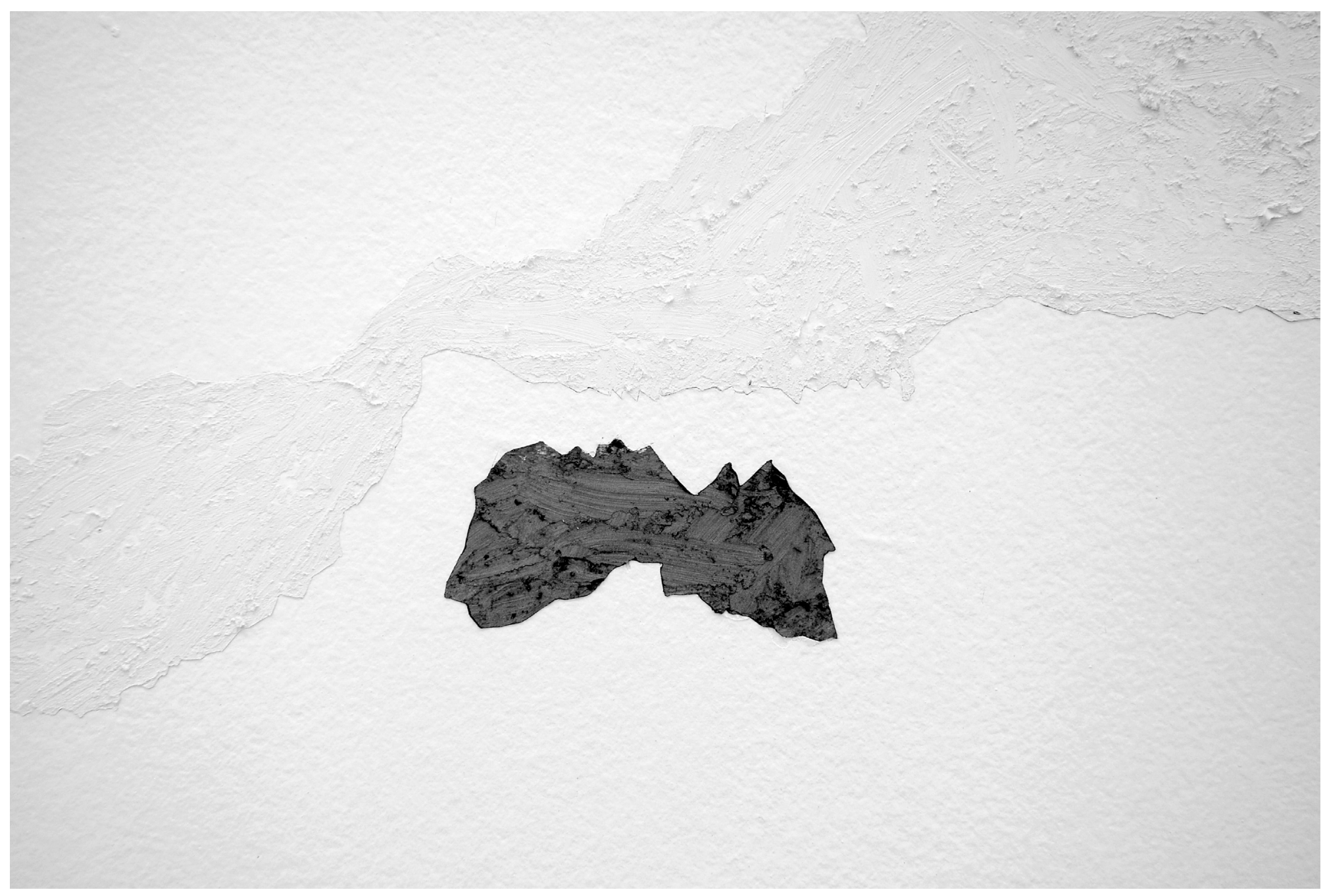

Figura 21: Gregório Soares, Paisagem tétrica, detalhe, sitespecific, $.30 \times 5$ m, 2014 . 


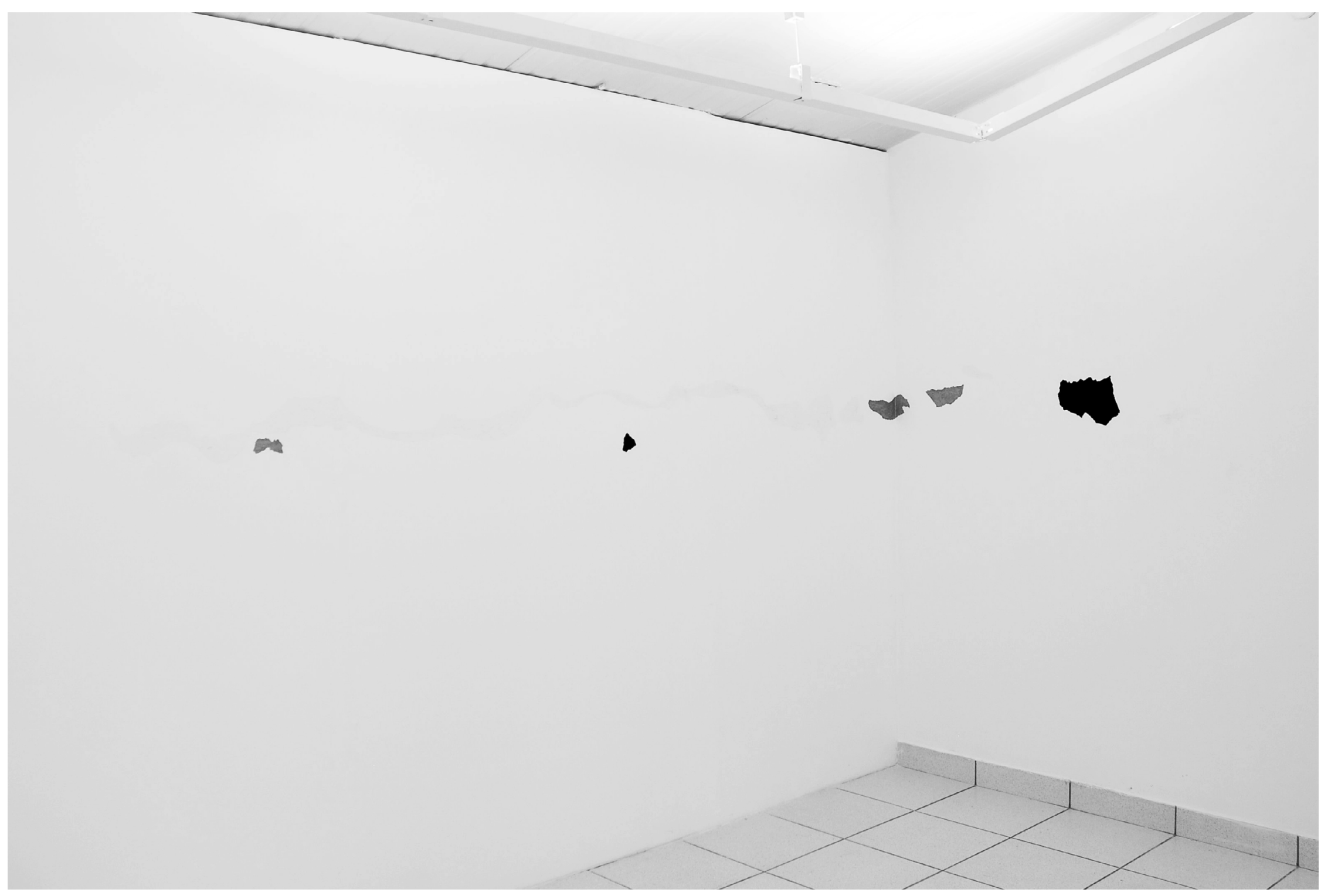

Figura 22: Gregório Soares, Paisagem tétrica, site-specific, .30 × 5 m, 2014. 


\section{1 a imagem presente por um triz:}

um fragmento em abismo

No começo há a ruína.

Jacques Derrida

Obviamente, destruir a pedra não é possível. Apenas a mudamos de lugar. De qualquer forma, ela durará mais que os homens que se servem dela. Por enquanto, ela apoia a vontade de ação deles. Mas, mudar as coisas de lugar é o trabalho dos homens: tem que escolher fazer isso ou nada. [...] Daqui a cem anos, ou seja amanhã, terão que recomeçar.

Albert Camus 
O objetivo deste capítulo, a princípio, é o de explorar uma preocupação que se encontra no centro dos meus interesses relativos à produção e reflexão poética, a saber: o caráter frágil das imagens/coisas no mundo. Tal fragilidade se refere diretamente à questão da matéria (literal/figural); ou seja, interessa-me tanto a matéria física, concreta, quanto a matéria figurada, alegórica, referente ao sentido. Assim, a tentativa aqui será a de compreender essa fragilidade da matéria a partir dos meus trabalhos ${ }^{35}$, que desconfio estar vinculada com a ideia de ruína e com o conceito de fragmento, que tentarei explorar adiante.

É possível afirmar, desde então, que todos os meus trabalhos, a partir de 2011, apresentam algum interesse de pesquisa pela materialidade (física e figurada) de certas coisas/imagens ${ }^{36}$ do mundo, sobretudo aquelas que estão em estado de ruína; isto é, as que estão próximas de perder o seu sentido primeiro, suas funções iniciais dadas por suas criações, prestes a desaparecer, que fracassaram em alguma medida; ou seja, revelam um interesse que apresentam algum desinteresse ou que se tornaram desinteressante para algum status quo. De outro modo, quando isso não ocorre, quando não as encontro simplesmente, acontece-me um interesse por

${ }^{35}$ Esta noção inicial de "fragilidade", bem como a ideia de "ruínas do presente", em relação aos meus trabalhos, são devedoras ao curador e poeta Luis Peréz-Oramas, abordadas em nossos diálogos "lejanos".

36 “[...] por 'imagem' entendemos uma certa existência que é mais do que aquilo que o idealista chama uma representação, porém menos do que aquilo que o realista chama uma coisa - uma existência situada a meio caminho entre a 'coisa' e a 'representação'”' (BERGSON, 1999, p. 2). 
realizar, transformar, construir (desconstruindo) coisas/imagens que apresentem essas características: a marca do tempo e sua consequente inconstância entre utilidade e inutilidade, função e disfunção, sentido, não-sentido e acaso.

Tentarei expor adiante, em forma de relato experiencial e crítico, como os processos da minha pesquisa poética se iniciam tendo estas premissas como tema e seus desdobramentos ${ }^{37}$ até chegarem nos trabalhos mais recentes, realizados no período do mestrado.

Ressalto de antemão que buscarei compor a estrutura deste capítulo em diálogo com a construção dos próprios trabalhos abordados. Portanto, em fragmentos, em abismo, relatos dentro de relatos, justaposição de conceitos e reflexões, em resumo, uma prática da analogia em processo. Aqui, as figuraseixo-metodológicas, previstas na introdução, atuarão efetivamente na construção do entendimento dos meus trabalhos. Assim, o texto se relacionará aporético, desviante, quiasmático e em montagem com as imagens dos processos e com trechos de diálogos e de referências conceituais e poéticas que comporam os interesses da pesquisa.

37 É importante esclarecer que os temas escolhidos para o relato crítico deste capítulo são apenas um recorte dentro dos possíveis interesses que cercam minha produção do período, não sendo interesse, assim, uma abordagem que tente algum tipo de esgotamento de leitura dos trabalhos. 
Para iniciar um mapeamento do interesse poético pelos "materiais" em ruína em meus trabalhos é preciso fazer um retorno rápido ao período da minha graduação em Artes Plásticas (UnB, 2008-2014), mais precisamente à disciplina "Pintura 1", na qual me dediquei a desenvolver uma pesquisa de representação pictórica a partir de fotografias de estruturas de madeira e concreto. $O$ processo iniciou-se com uma identificação e registro fotográfico de estruturas que tinham a função de sustentar determinadas construções arquitetônicas. Em seguida me propus a re-apresentar ${ }^{38}$ pictoricamente tais registros. $O$ resultado foi a série de trabalhos que intitulei "ex-truturas" (figura 10), onde a decisão última foi pintar à óleo sobre fotografias fragmentadas de pilotis do Plano Piloto de Brasília.

A tentativa alegórica destes trabalhos era (e ainda é) a de, alguma maneira, metaforicamente arruinar essas estruturas de sustentação. Tornar o mais rígido em algo mais frágil. Subvertendo (gentilmente ${ }^{39}$ ) a função dos signos de um possível imaginário visual da cidade de Brasília, por meio da relação entre fotografia e pintura.

38 Opto por esta grafia da palavra como alternativa à palavra "representação", por compreender a complexidade e a problemática que este conceito possui e que não poderei discutir neste trabalho. A ideia, com "re-apresentação", é que ela ofereça uma compreensão para além da ideia do ato de representar e marque a possibilidade de ser, de outro modo, uma apresentação também, que desvincula a imagem de seu referente.

${ }^{39}$ Utilizo-me desta ressalva pois acredito que os trabalhos desta série funcionam também como uma homenagem à obra de Athos Bulcão e não são apenas parte de um ato que subverte algumas de suas premissas (subversão esta que, aliás, o próprio Athos lançava mão, vide citação do Paulo Herkenhoff adiante). 
Posterior à série "ex-truturas", dou inicio a outra intitulada "estruturas equívocas", que subdividiu-se em três trabalhos: "pilotis", "autorretratos" e "fissuras", (figuras 13, 15 e 16). Com as mesmas premissas, a ideia basilar foi pensar as especificidades de cada proposta dentro do campo da fotografia, inaugurando um interesse que irá girar em torno dos trabalhos do Athos Bulcão, especificamente sobre seus painéis de azulejos. A questão ainda foi pensar, a partir da leitura de um artista consagrado, o estado da imagem de sua obra em relação à cidade da utopia moderna.

Em "pilotis" (figura 15) meu interesse estava centrado no processo de montagem dos azulejos, do qual lançava mão o próprio Athos, conforme lembra Agnaldo Farias, a "aplicação" dos painéis era:

deixada sempre a critério do operário encarregado, um critério que, segundo o artista, tem o mérito de ser "deseducado", isto é, sem o gosto pelo equilíbrio ou mesmo pela desordem arrumadinha incutida pelas nossas escolas. Cada unidade vai se juntando com a outra num todo aleatório, de ritmo sincopado, cuja sequência nos é impossível apreender de bate-pronto (Farias, 2009, p. 395). 
Após fotografar e imprimir em preto e branco as imagens de determinados pilotis, o trabalho se baseia na colagem dos fragmentos recortados em tamanhos quadrados iguais, proporcionais aos azulejos, e remontados em um plano. $\mathrm{O}$ resultado é um jogo construtivo, tal qual proposto por Athos, mas que joga com a memória da imagem anterior, "unida", "individual", pretensamente "singular", transformando-a e multiplicando-a. Cada elemento passa a ser um "quadro" dentro do "quadro", uma re-apresentação em abismo ${ }^{40}$ que coloca em cheque o caráter da representação fotográfica fidedigna e flerta com a abstração da forma construtiva.

${ }^{40}$ Remeto nesta questão à expressão francesa mise en abîme ou mise en abyme: "O termo mise en abyme é operacionalizado por André Gide, em 1893, a partir de um sentido bastante preciso: em uma narrativa, o mise en abyme corresponderia ao fragmento de um texto capaz de reproduzir, tal como uma miniatura, o texto em sua inteireza, o todo do texto" (Casadei, 2012, p. 132). 
Tal trabalho é, de certa maneira, tributário e faz diálogo com uma tradição da fotografia experimental moderna que, por sua vez, herdou um conhecimento técnico pela tradição pictorialista ${ }^{41}$ :

O experimentalismo moderno veio desequilibrar a dinâmica figurativismo/abstracionismo. A partir dele o real passou a ser apenas o estímulo inicial do fotógrafo, simples matéria-prima a ser posteriormente manipulada (Costa e da Silva, 2004, p. 84).

Certamente, uma das principais referências dessa fotografia, no Brasil (e para meu trabalho atualmente), é Geraldo de Barros (que fui descobrir um pouco mais tarde da realização dessa série). Seu trabalho intervém de maneira contundente nos processos de ampliação, após captura, compreendendo a fotografia como matéria de experimentação plástica, de forma a perder a referência do real ou mantê-lo em tensão com as formas finais. Segundo Helouise Costa e Renato da Silva, esse processo faz parte de uma estratégia eminentemente modernista pois, além de repensar a figuração, modifica a operação obra e público; "nesse processo de reconstrução, especificamente com relação à fotografia moderna" o observador:

${ }^{41}$ Proporei uma maior discussão das referências teóricas sobre a fotografia no terceiro capítulo. 
se vê forçado a alargar sua percepção (...) no momento em que é quebrada a integridade do objeto na imagem, o observador é obrigado a repensar o papel que ocupa diante da realidade e, com isso, reatualiza a relação direta e imediata que anteriormente existia entre ele e o objeto (2004, p. 85).

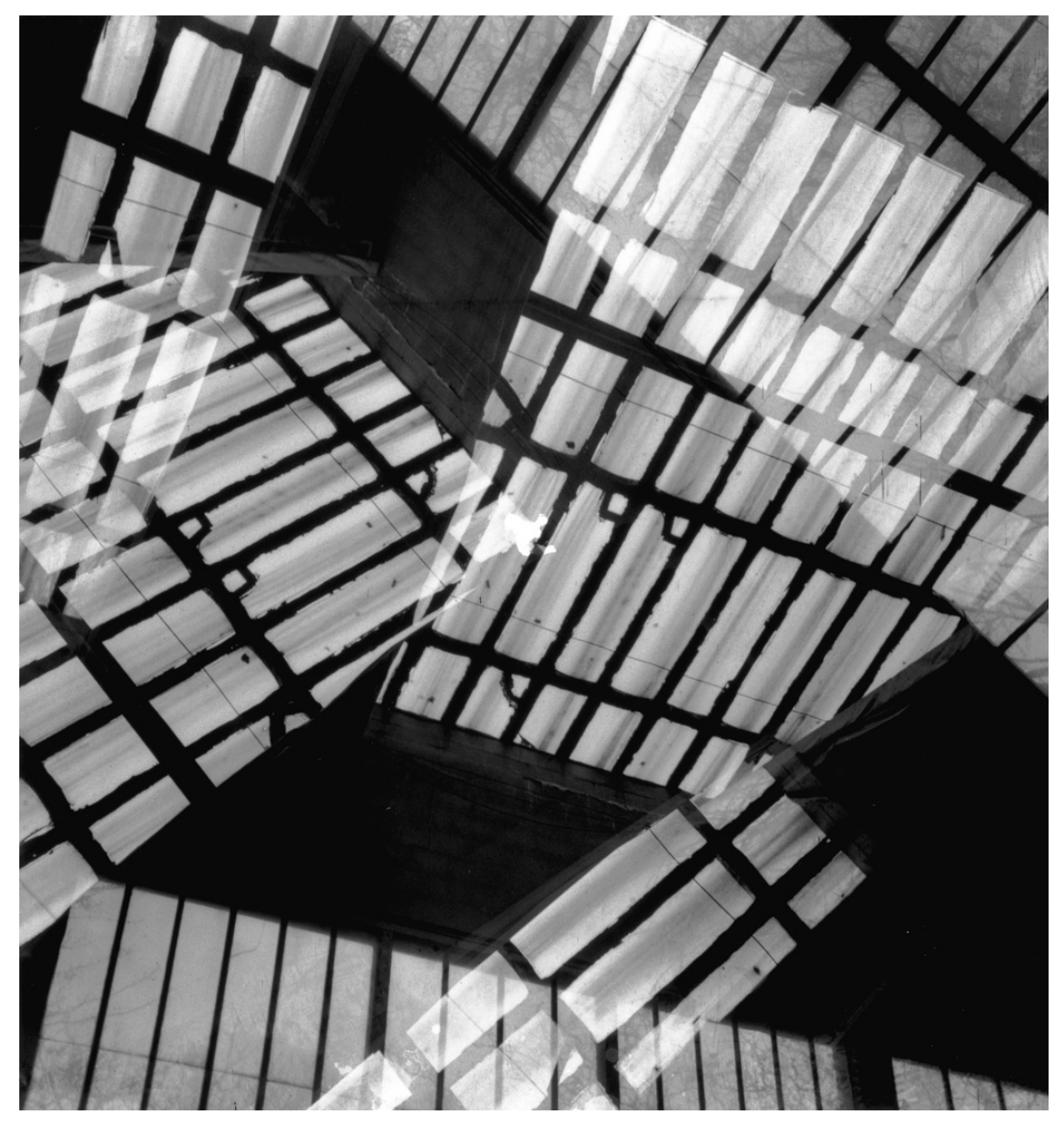

Figura 23: Geraldo de Barros, sem título, fotografia, 1951. 
O meu diálogo com os azulejos do Athos se intensifica nos trabalhos "autorretratos", (figura 13), e "fissuras" (figuras 15 a 17). No primeiro, aproprio-me de restos, pedaços, cacos de um dos murais do $\operatorname{artista}^{42}$ e a partir deles, por assemblage, remonto formas, combinações e composições à minha maneira e fotografo digitalmente o resultado em seguida. A série é constituída por dez fotografias em preto e branco, subvertendo não apenas o arranjo original do mural mas também suas composições cromáticas.

O título, "autorretratos", se deu pois me interessou abordar os limites da ideia de apropriação bem como do próprio autorretrato. De alguma maneira, o objetivo era o de explorar os sentidos de autonomia, autoria e identidade da obra artística, interseccionando meu trabalho ao do Athos, dentro de uma categoria tradicional da história da arte. No entanto, apesar do resultado ser um registro fotográfico, o trabalho não se enquadra na tradição da autorrepresentação pela fotografia, já que não estou fisicamente diante da minha própria câmera. A identificação é com o próprio objeto e este é uma metáfora da minha presença, uma ficção de mim. No limite, poderia ser identificado com o que Annateresa Fabris (2004), em seu texto “O auto-retrato acéfalo", propõe quando ocorre essa ausência da autorrepresentação de partes do corpo que constitui os principais elementos de identificação pessoal (sobretudo, a cabeça e o rosto). No limite porque, em meu caso, meu corpo está

\footnotetext{
42 Todas as apropriações de pedaços dos azulejos foram feitas no mural localizado na Universidade
} de Brasília, no prédio alocado o Departamento de Artes Cênicas. 
totalmente ausente da apresentação, seguindo o que aponta Fabris: "o que importa (...) não é a identidade, e sim a Alteridade secreta, aquela máscara que torna o indivíduo singular, que o transforma em 'coisa entre as coisas'" (2004, p. 14).

Neste trabalho, a matéria frágil, em ruína, que identifico, além dos azulejos da própria obra do Athos, do autorretrato na História da Arte, da fotografia enquanto representação, é também este sujeito proponente, que diz "eu" e também não se reconhece enquanto indivíduo, "uno", senão muitos, fragmentados, ligados sempre a outros.

O retrato e a autoria retornam para os seus lugares mais habituais em "fissuras", e o gesto fotográfico se alinha mais ao voyeur moderno, observante e documental, que "apenas" registra os azulejos ausentes dos murais. Sobre este trabalho, cito o que foi observado por Matias Monteiro quando escreveu que:

Gregório nos revela, através dos espaços vazios deixados por azulejos faltantes, as marcas da espátula e o trabalho manual quando da instalação como uma geologia secreta. Nessas ruínas do projeto moderno possibilitam uma nova experiência modernista: uma cidade subterrânea que pode ser vivida não por suas características estéticas arquitetônicas, mas exatamente por aquilo que a opõe (Monteiro, 2013, p. 215). 
Nessa tentativa de "oposição" à cidade monumental, "fissuras" é uma busca por esses espaços de contraste por dimensão e escala com a arquitetura moderna. É tentar expor os detalhes do que não foi previsto no projeto utópico (e normalmente não é previsto nos projetos de modo geral) e que é revelado pouco a pouco, com a passagem do tempo: eu diria, sua própria desconstrução.

Antes de prosseguir com os trabalhos posteriores, em ordem cronológica a esta série, que também dialogam com os temas da fragilidade, da ruína e dos fragmentos, gostaria de saltar para um dos meus últimos trabalhos realizados no período desta dissertação que ainda explora o diálogo com os azulejos. O título completo deste trabalho é "paisagem tétrica II: coleção de cacos (ou, rodapé)" (figuras 18 a 20).

A partir de um convite para intervir em uma fachada externa de uma galeria em Brasília (Alfinete Galeria), me propus a realizar um trabalho que, desta vez, dialogasse com um aspecto dos murais que até então eu não havia arriscado. Trata-se da ocupação espacial que sempre está em questão nas intervenções arquitetônicas realizadas por Athos Bulcão, sejam nos murais de azulejos ou nos relevos cromáticos, tão conhecidos no Hospital Sarah Kubitschek e no Teatro Nacional de Brasília.

Desde os meus primeiros contatos com os murais de azulejos fotografados nos primeiros trabalhos, localizados na UnB, já havia identificado que abaixo de três dos painéis (o prédio contém um total de quatro) foram construídos valas de escoamento de água e, provavelmente, para entrada de luz e ventilação no andar 
subterrâneo do prédio. Percebi, então, olhando de cima, que nestas valas foram se acumulando, pelo acaso do tempo, cacos dos azulejos caídos dos murais. Depois de alimentar por alguns anos o desejo de recolher estes fragmentos, decidi fazê-lo para realizar a intervenção na fachada e coletei centenas destes cacos enterrados.

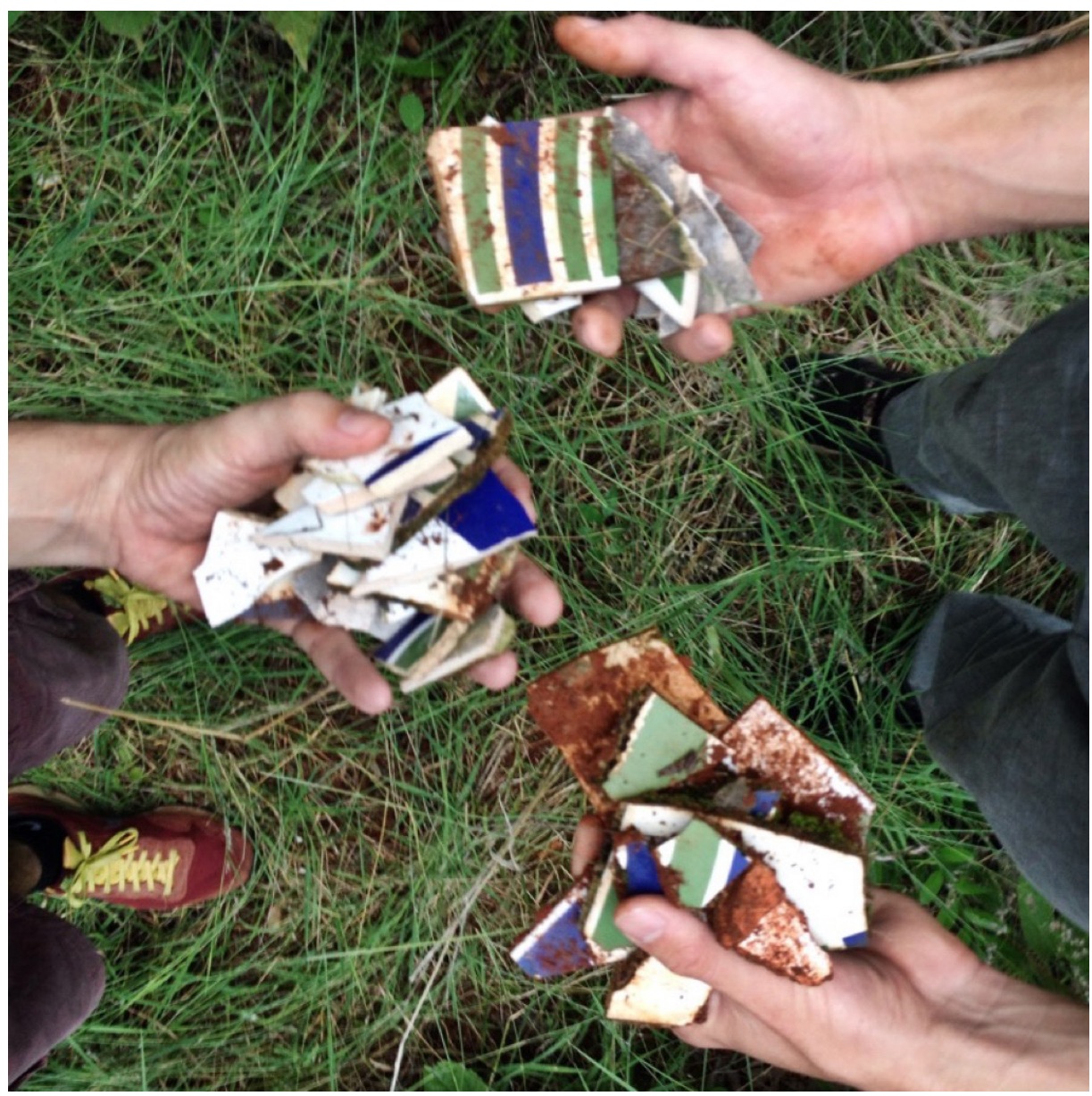


No entanto, estas centenas de cacos ainda não eram suficientes para cobrir dez por cento da fachada. Foi então que me propus a re-construir a parte mais frágil dos painéis de azulejos do Athos Bulcão: o rodapé; ou a ausência deste, pois os murais não possuem rodapés. Devido essa ausência, são os primeiros a manifestarem o peso implacável do tempo sobre a matéria no espaço: por estarem mais próximos aos solos recebem mais umidade e estão sempre mais expostos às ações das limpezas dos pisos, são, portanto, os primeiros a sofrerem manchas e fissuras.

Para essa re-construção optei por realizar um "rodapé" suspenso, enaltecido, ocupando a linha do horizonte da fachada por meio de uma linha mesma de mosaico. A regra do processo de montagem foi alinhar cada fragmento por seu lado mais reto para baixo. Mantendo o objetivo de subversão das regras originais do material, o resultado deste trabalho é o de um mural inacabado, se pensarmos em relação aos murais do próprio Athos que ocupava toda a extensão da superfície que tinha a sua disposição, de maneira planar, tributária ao "muralismo pictórico", que por sua vez é a precedência histórica dos painéis construtivistas do Athos Bulcão.

O resultado gráfico e pictórico da intervenção também subvertem a ordem original do modelo, pois os desenhos cromáticos originais dos azulejos se desencontram pela montagem do mosaico (que, aliás, por si só, já se trata de uma técnica que subverte o uso da matéria original, nova, íntegra, do azulejo novo), bem como a dimensão regular em seu formato quadrado, normalmente de fundo branco. O fundo da intervenção não é branco, para ressaltar e iluminar os desenhos 


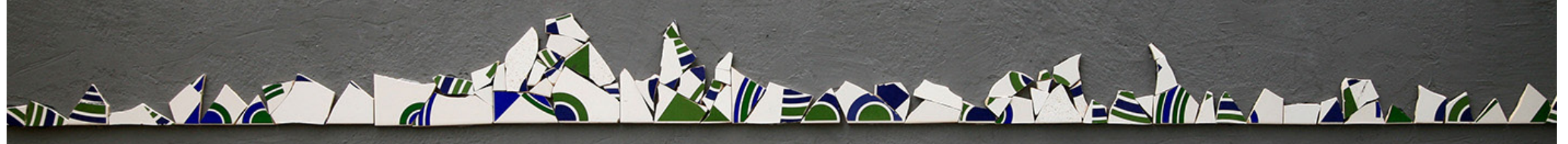


internos de caráter construtivistas dos azulejos; mas cinza escuro, noturno, para contrastar e enfatizar os desenhos externos, espontâneos, únicos pois impossíveis de mimetizar, de cada um dos fragmentos.

Após esta intervenção foi possível perceber que a "matéria" desta série de trabalhos, em diálogo com os murais de azulejos, foi se transformando por um caminho que passou da abstração material mais pura (as fotografias das "fissuras"), depois pelo início de uma materialização de fato, mas ainda abstrata em seu resultado final (as fotografias dos "autorretratos"), até chegar neste último trabalho que se deu pela utilização da própria matéria bruta dos azulejos, sem a intermediação abstrata da fotografia.

Para que seja possível discorrer sobre este título ["paisagem tétrica II: coleção de cacos (ou, rodapé)"], se faz necessário voltar ao trabalho anterior, "paisagem tétrica" (figuras 21 e 22), pois é a partir dele que o título aparece, junto com uma abordagem em torno das noções de site-specific, ruína, fragilidade e tristeza da forma, que tentarei abordar em seguida. 
"Paisagem tétrica", foi um trabalho realizado como proposta de site-specific, integrando a exposição chamada "Ocupação", realizada entre os meses de Julho a Setembro de 2014, no espaço do Elefante Centro Cultural, em Brasília. A exposição, proposta pelo curador uruguaio Manuel Neves, teve como mote a disponibilidade de "ocupação" de todos os espaços físicos do Centro pelos artistas selecionados por meio de chamada pública.

Em ocasião da realização do trabalho escrevi uma nota resumida sobre as decisões tomadas no processo, que transcrevo a seguir:

As cascas retiradas das paredes do espaço Elefante, tétricas, me perguntaram para onde estavam indo, solicitando em coro sua restituição. Por minha vez, prometi-Ihes resguardo e deferência. Elas, em graça, mostram o mundo possível nos desenhos de seus contornos. Entre as linhas em ruína à oleosa solidez do branco sujo, do prata quase cinza e do preto opaco, insinuam paisagem. Retornam, reapresentadas e imponderáveis, situam-se entre o íntimo da pintura, da pele-casca e o ausente do horizonte. Paisagem tétrica, portanto, do pouco ao quase nada, um ininterrupto movimento de revisão do si do espaço específico. 
Esta nota já me parece ser bastante evidente sobre as decisões e motivações do trabalho mas tentarei esmiuçá-las um pouco mais, contextualizando-as.

É possível dizer que a regra basilar deste trabalho foi a de não ter uma ideia pré-vista, estabelecida em mente para ser realizada. Meu objetivo inicial foi o de entrar no espaço com uma câmera fotográfica digital e fazer registros que poderiam me indicar possíveis ideias para uma intervenção específica. Como se o trabalho fosse uma leitura daquele espaço enquanto forma e conteúdo em relação conjunta. Cheguei a ir duas vezes no espaço do Centro para realizar estes registros. Foi então que no segundo ou terceiro dia me deparei com alguns pintores que estavam preparando as paredes para a próxima exposição e junto a eles uma grande quantidade de cascas das paredes que seriam descartadas. Resultado: as cascas viraram a matéria prima do trabalho.

Do projeto de registro fotográfico o trabalho se transformou em uma intervenção pictórica. Transferido os desenhos de contorno das cascas para as paredes, com o auxílio de um estêncil feito de fita cobri os desenhos com tinta de bastão a óleo em três cores: branco "sujo", prata "quase cinza" e preto "opaco". Os desenhos das cascas viraram uma paisagem de peles ou ilhas de tinta. 


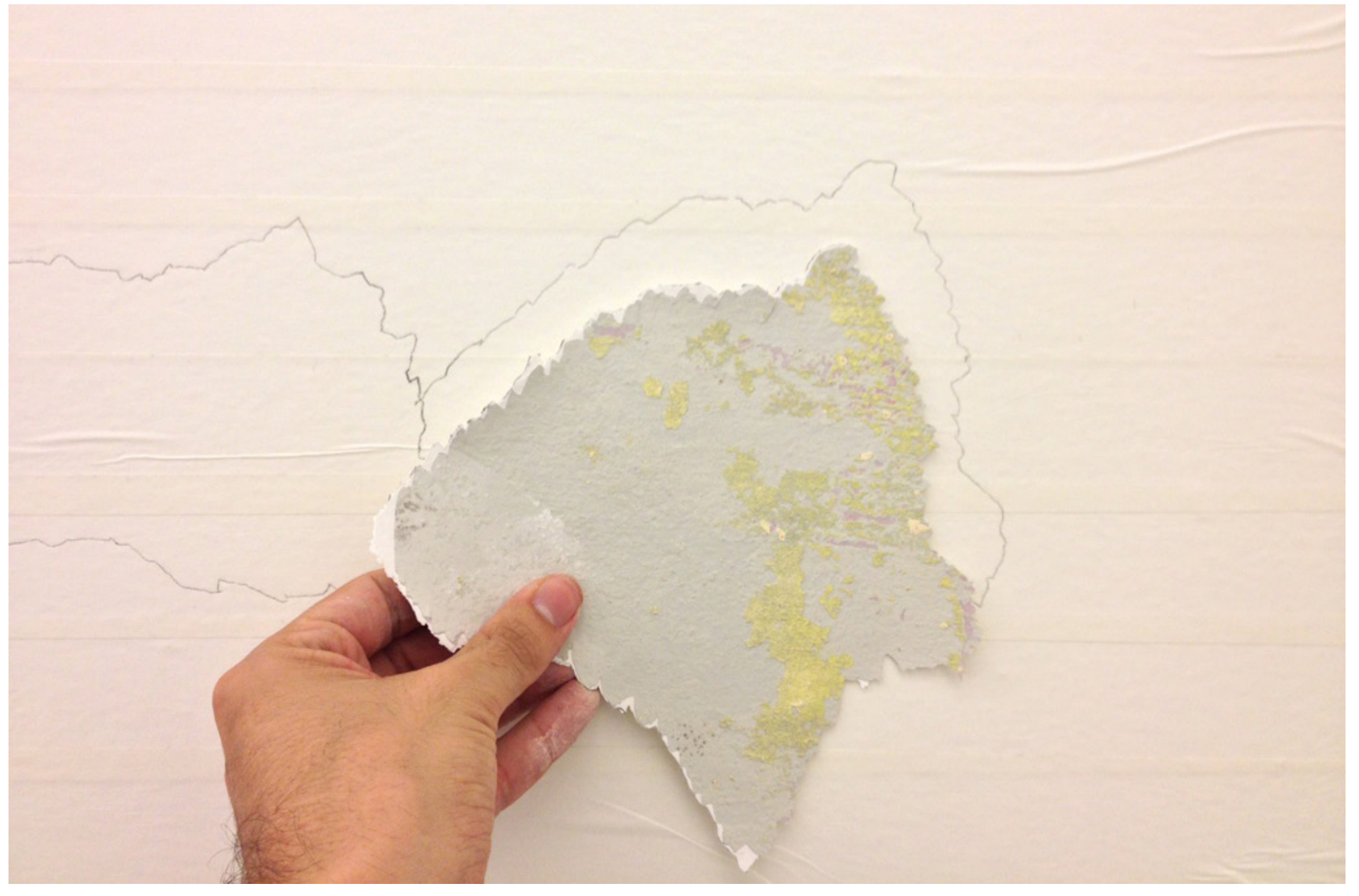

Figura 26: Gregório Soares, Paisagem tétrica, registro de processo, 2014. 
Logo depois de concluído, entre agosto e setembro de 2014, este processo foi comentado em um diálogo com uma amiga escritora de São Paulo, chamada Dani Gutfreund, que preparava um texto sobre alguns aspectos de meus trabalhos; também transcrevo uma parte a seguir pois nela discorremos (de forma espontânea) sobre a decisão do título, alguns aspectos do resultado final e como a intervenção se relaciona com outros aspectos de trabalhos anteriores:

Dani Gutfreund: talvez pudéssemos começar falando do título de seus trabalhos. de modo geral, entendo a relação ou contrarelação proposta, como se seus títulos trouxessem um outro dado, fundamental, ao trabalho. desviando ou complementando, sempre firme, algumas vezes categoricamente, o espaço inaugurado pelo trabalho. no caso de paisagem tétrica, não. procuro um jogo qualquer que possa estar escondido. te pergunto das cores, pois havendo quatro se justificaria o tetra, daí surgindo o jogo. como se quebrasse a rigidez da palavra, oferecendo outras possibilidades a ela. talvez. ainda que haja decisão no desenho, na busca da tinta, cujas camadas rasgam a parede, confundindo o que foi ali colocado com o que se perdeu, não vejo severidade, mas uma mão que tateia o caminho, desenhando o trajeto no movimento da massa, que se faz relevo e ausência. fala um pouco disso para mim? do nome, do fazer cauteloso que se percebe em cada trecho, 
do risco que cria e de criar. desse tomar à frente, que aparece, a meus olhos, pela primeira vez, em seu trabalho pensado enquanto tal. e também disso que você diz, de achar bom que não seja tétrico o trabalho. de seus títulos. da palavra e do corpo.

Eu: Sim. Os títulos são tão importantes no processo que as vezes acho que eles tendem a ser uma segunda coisa... Mas, são sempre para mim um exercício de reflexão paralelo, acontece antes $e$ depois. E faz parte de um momento que é um pouco diferente do processo de criação do trabalho visual. Mas está sempre ali, presente, em tensão absoluta com a matéria-corpo. Além disso, eles me ajudam a manter uma relação entre os trabalhos. $O$ que revela uma tendência minha em trabalhar com séries, com um certo processo interno que demoro a resolver ou a explorar suficientemente em apenas uma obra. Paisagem tétrica acho que é uma exceção, neste sentido. É um trabalho muito específico. Em que eu aceito o desafio, o risco, de navegar no quase desconhecido: quando entrei no espaço da exposição não tinha a mínima ideia do que iria fazer. Eu quis me colocar nessa situação... ou talvez, já venho me colocando. Faz parte de uma vontade de querer me surpreender, de deixar que o trabalho se revele a partir da minha vivencia nua no espaço. Nua no sentido que me dispo do que eu 
sei tecnicamente sobre alguma linguagem, algum material, algum saber anterior. É um confronto com o desconhecimento: meu em relação àquele espaço-mundo: e o trabalho é resultado desse confronto (que pode ser amistoso ou conflituoso). Essa vontade é fruto de uma certa descrença em relação ao "mundo", não só o da arte. Um "mundo" excessivamente propositivo, pouco generoso, prolixo, sempre em oferta... medroso do desconhecido, da falta do sentido, por fim, medroso do silêncio. Tudo isso gera um sintoma grave, ao meu ver, que é a perda da despretensiosidade. Acho que perdemos absolutamente o valor da despretensão, que é um estado (de espírito) muito caro à poética. Vivemos a muito tempo num mundo da urgência... (isso não é novidade!) mas ainda precisamos aprender a lidar com isso... Bom, um pouco disso pra falar do título. Desculpe mas foi inevitável o desvio. Essa descrença com um mundo vitorioso me faz voltar para outro lado: o da derrota, dos vencidos, dos perdedores, dos mortos... Eu sempre quero saber porque, pra quem e o que alguém perdeu... Me interessa o que se perde, o que se esquece, os tristes, portanto, tudo o que é tétrico. Encontro sempre ruínas aí... ou, caso contrário, sinto vontade de construí-las, contribuir com elas. Acho que escolhi "tétrica" porque me revela uma tristeza sempre presente em meus trabalhos. Fora este aspecto, que é mais pessoal, que é 


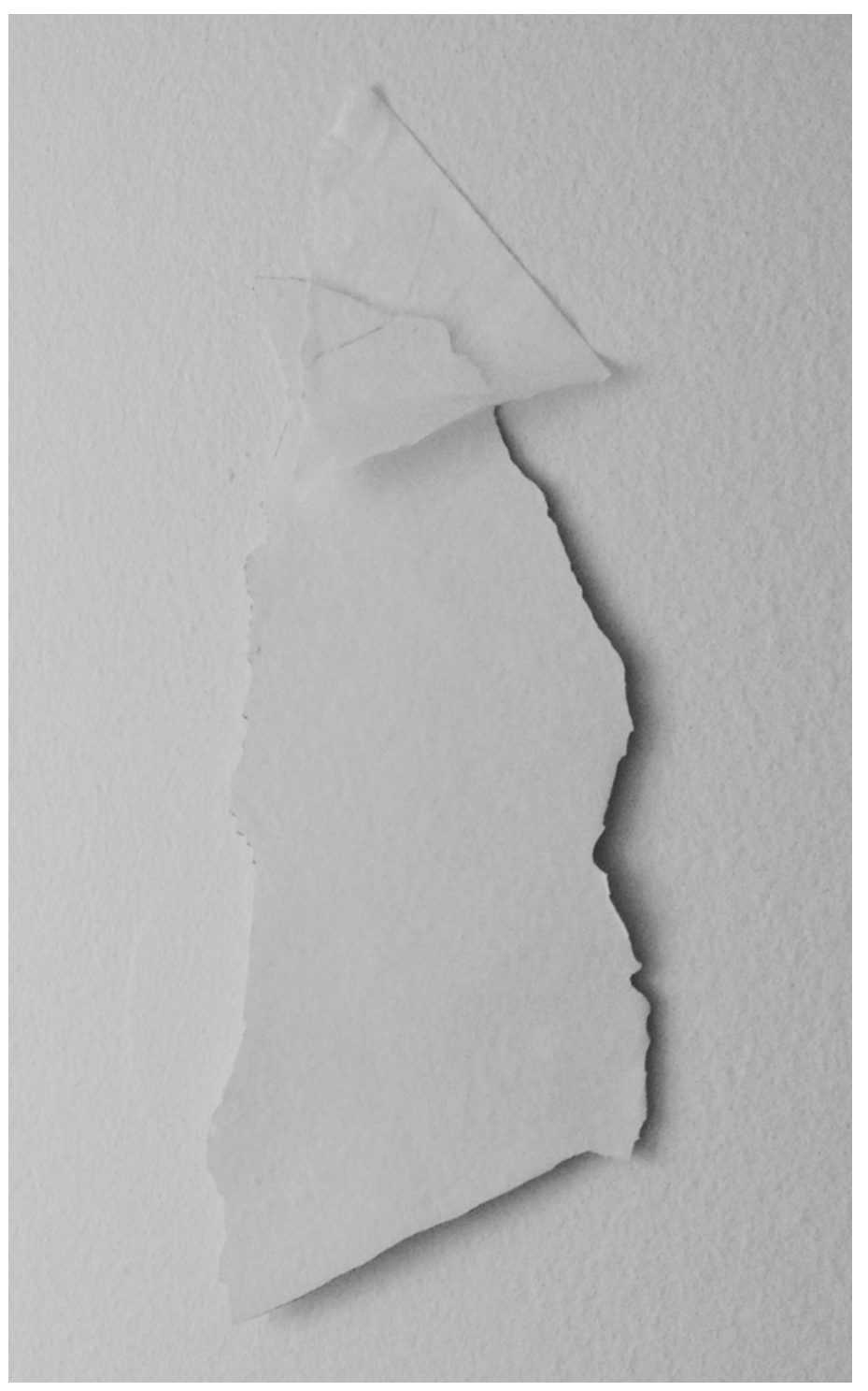

Figura 27: Gregório Soares, Paisagem tétrica, registro de processo, 2014. mais um problema de sujeito em relação ao mundo, penso que tétrica revela ainda um interesse que tenho na sonoridade das palavras (acho que você acerta em pressupor que exista uma vontade de oferecer uma outra possibilidade para a palavra)... ela me leva muitas vezes para "geomé-trica"... (que vai de encontro a uma preocupação construtiva em meus trabalhos). Gosto de descobrir um movimento interno da forma da palavra (e também das formas das coisas) que são quase ilegíveis, pois estão fora de uma instituição de inteligibilidade, de comunicabilidade, e que me coloca também nesse lugar de generosidade com o sentido. Bom, e nesse trabalho eu procuro também esse caminho de cruzamento entre uma certa rigidez do pensamento e uma organicidade da forma e da palavra (no título), do concreto-mundo à mão que "tateia", que desenha e pinta "livremente", sem severidade, como uma manifestação política diante de outras severidades, que são apenas as de um "mundo" em progresso desvairado. Agora, quando disse que acho bom que não seja lido no sentido habitual de "tétrico", é que este sentido já está dado, ele é explicativo, um dado ilustrativo, representativo da palavra, que eu encontro menos neste trabalho. Você pôde constatar: não é tétrico! Sei que assumo um risco neste sentido... de usar a palavra em um sentido outro, mas talvez seja este risco o que realmente interessa. 
Dani Gutfreund: queria começar por isso de seus títulos serem "uma coisa um pouco diferente do processo de criação do trabalho visual", embora atrelados a eles e, mais, criando ou fortalecendo o vínculo ou conexões entre os trabalhos. Os títulos que denominam as séries também têm conexões entre si, e permeiam mais de uma, como se formassem uma cadeia com eles, que derivam, um de outro, que se revisitam, possibilitando o que poderiam ser "diálogos impossíveis" não fosse a forte carga conceitual que os agrega. E depois pensar nessa coisa do "Paisagem tétrica" de novo. Sem dúvida, ele e "Pairos III" são marcos em seu trabalho, encerram e inauguram questões, enquanto carregam toda sua trajetória poética neles. Engraçado falar da tristeza, de fato presente nos seus trabalhos, porque embora esteja ali, você a contorna, reconstrói, cria situações que diminuem ou desafiam a solidão, contando sempre com o acaso, mesmo que tenha que ajudar, com sua mão, tal destino, gerando um novo lugar, habitável, onde há certa tranquilidade e alívio, onde há possibilidade de se reconstruir. Quanto ao tétrico da Paisagem, depois de escrever a primeira pergunta, me encontrei com ele: nas ilhas isoladas, ausências, no quase desespero de criar caminho. Vamos falar do acaso que se faz presente em todos os trabalhos? 


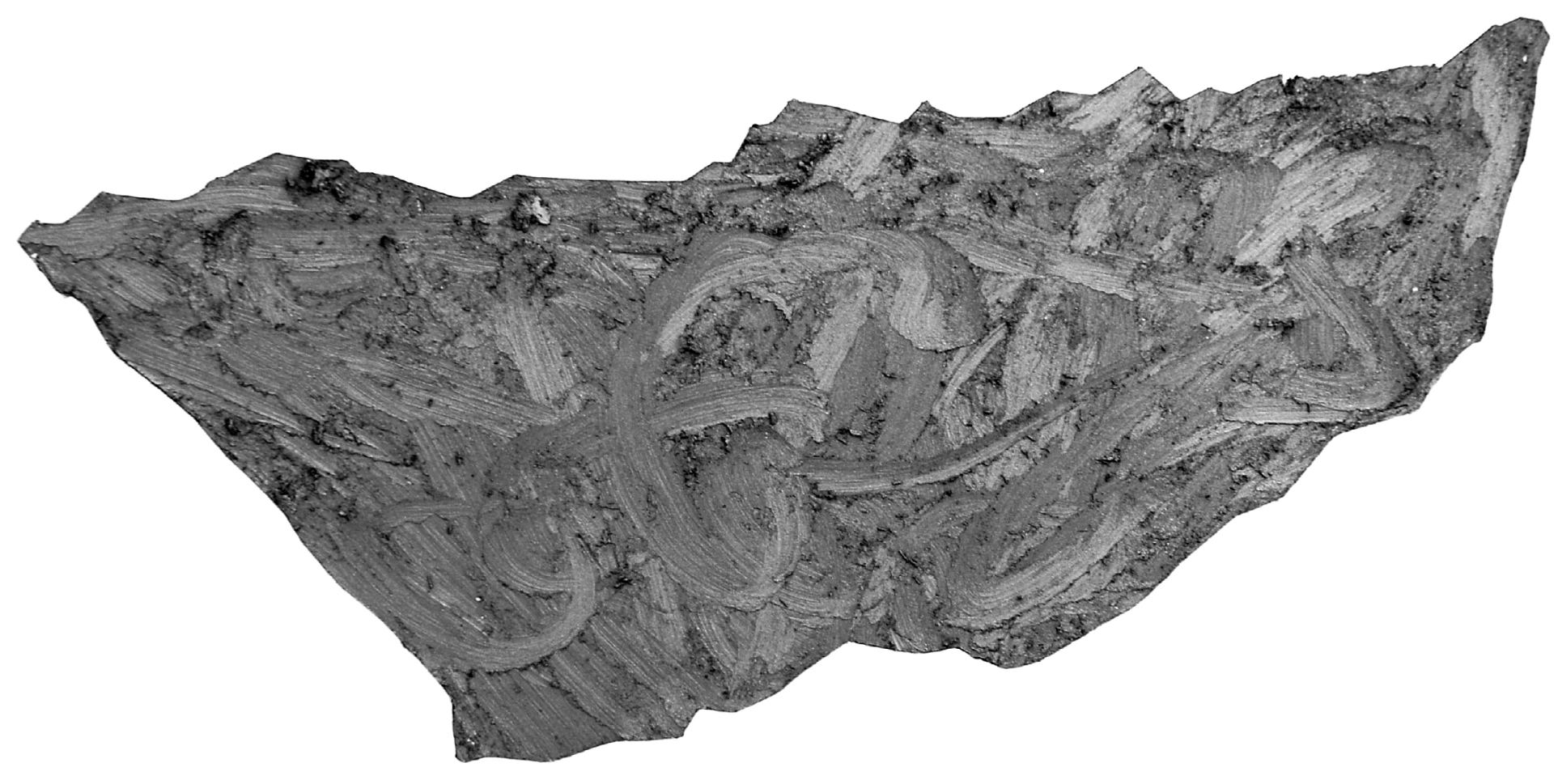

Figura 28: Gregório Soares, Paisagem tétrica, detalhe, 2014. 
O diálogo inevitavelmente toca em questões que extrapolam os objetivos previstos neste capítulo e não poderei estendê-lo. Mas, o intento, por meio destes fragmentos, é mostrar como os fins gerais deste capítulo passaram (e passam) no processo de pesquisa e realização dos próprios trabalhos, da concepção dos títulos à feitura material, bem como os interesses por certas categorias, tais como: o problema do autorretrato, as questões da ruína, do fragmento, e o embate intermitente com os sentidos (teóricos/poéticos) do trabalho, os visíveis e os invisíveis.

Este é, assim, um testemunho, um compartilhamento, a partir dos meus trabalhos, da fragilidade da matéria presente, um projeto de reconhecimento das impossibilidades da imagem e sua estrutura arquitetônica, rígida e impositiva. Ou seja, um exercício contra a monumentalidade, tal como uma via "non-u-mental"43, para usar uma definição do artista nova-iorquino Gordon Matta-Clark, integrante da cena underground das décadas de 60 e 70, que já atacava aspectos da arquitetura no que "diz respeito à ilusão de perenidade, eficiência e ordem que nela se materializa, tornando-a uma poderosa metáfora do status quo social” (Wisnik, 2006).

Mas, pode-se dizer, que a obra de Matta-Clark é um anti-monumento que atua na própria estrutura do monumento, no espaço urbano em suas dimensões

43 “Busco edificações típicas que apresentam certos tipos de identidade histórica e cultural. Mas o tipo de identidade que me interessa precisa ter uma forma reconhecível. Uma de minhas preocupações aqui é com o Non.u.mental, ou seja, [com] uma expressão do corriqueiro que possa se contrapor à grandiosidade e pompa das estruturas arquitetônicas e de seus clientes, empenhados apenas em se glorificar". Em: "Gordon Matta-Clark's Building Dissections. Interview by Donald Wall", citado em Cuevas, 2010, p. 25. 
reais, seu trabalho atua dentro da lógica urbanista mesma, seja por meio das intervenções diretas nos edifícios/casas/etc ou em seus filmes. E suas ações, assim como essa matéria que não permanece, que tanto me interessa, apesar de suas grandezas, nenhuma sobreviveu fisicamente, todas foram demolidas

e seus trabalhos só existem atualmente enquanto registros documentais.

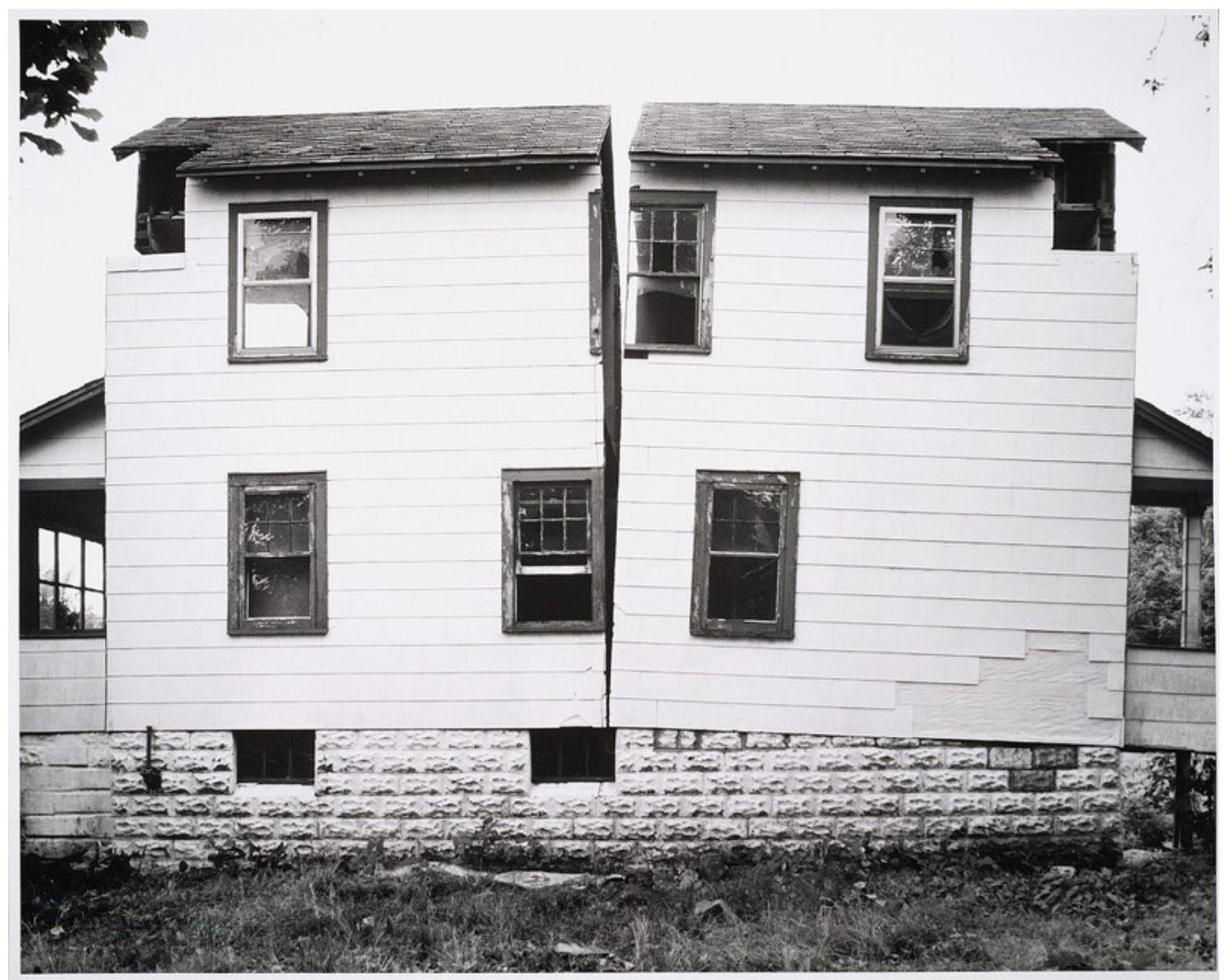

Figura 29: Gordon Matta-Clark, Splitting, 1974. 
As ações de Matta-Clark, é claro, também se interessaram pelos gestos de fissurar, quebrar, rasgar, dividir, do mesmo modo, de fragmentar o caráter fixo e rígido de certas estruturas de sustentação de um poder simbólico provisório. Seu trabalho, como o de artistas e pensadores que se interessam pelo fragmentário ${ }^{44}$, sugere uma ideia de "desordem" que "é necessária" pois "a força do Fragmento está precisamente em suas potencialidades anárquicas que provocam tensões", como sugere Paola Berenstein Jacques:

O Fragmento é a força daquilo cuja natureza não conhecemos, daquilo que não oferece qualquer garantia de atualização. O Fragmento semeia a dúvida. Ele pode ser um pedaço, uma etapa ou um todo, inclusive, o contrário de si mesmo. $\mathrm{O}$ acaso se instala. A arquitetura tem grandes dificuldades em enfrentar os riscos do acaso, do aleatório, do arbitrário, do fragmentário (Jacques, 2003, p. 44).

\footnotetext{
${ }^{44}$ Uma das reflexões mais relevantes em relação à ideia de fragmento, acaso e aleatoriedade, é a elaboração de Claude Lévi-Strauss sobre o termo bricoleur, para designar o "pensamento selvagem" dos povos primeiros ou primitivos. "A poesia da bricolagem", diz o pensador, "Ihe vem também e, sobretudo, daquilo que ela não se limita a terminar ou executar. Ela 'fala' não somente com as coisas, mas também por meio das coisas: conta, por meio das escolhas feitas entre possíveis limitados, o caráter e a vida de seu autor", em La pensée sauvage, citado por Jacques, 2003, p. 25.
} 

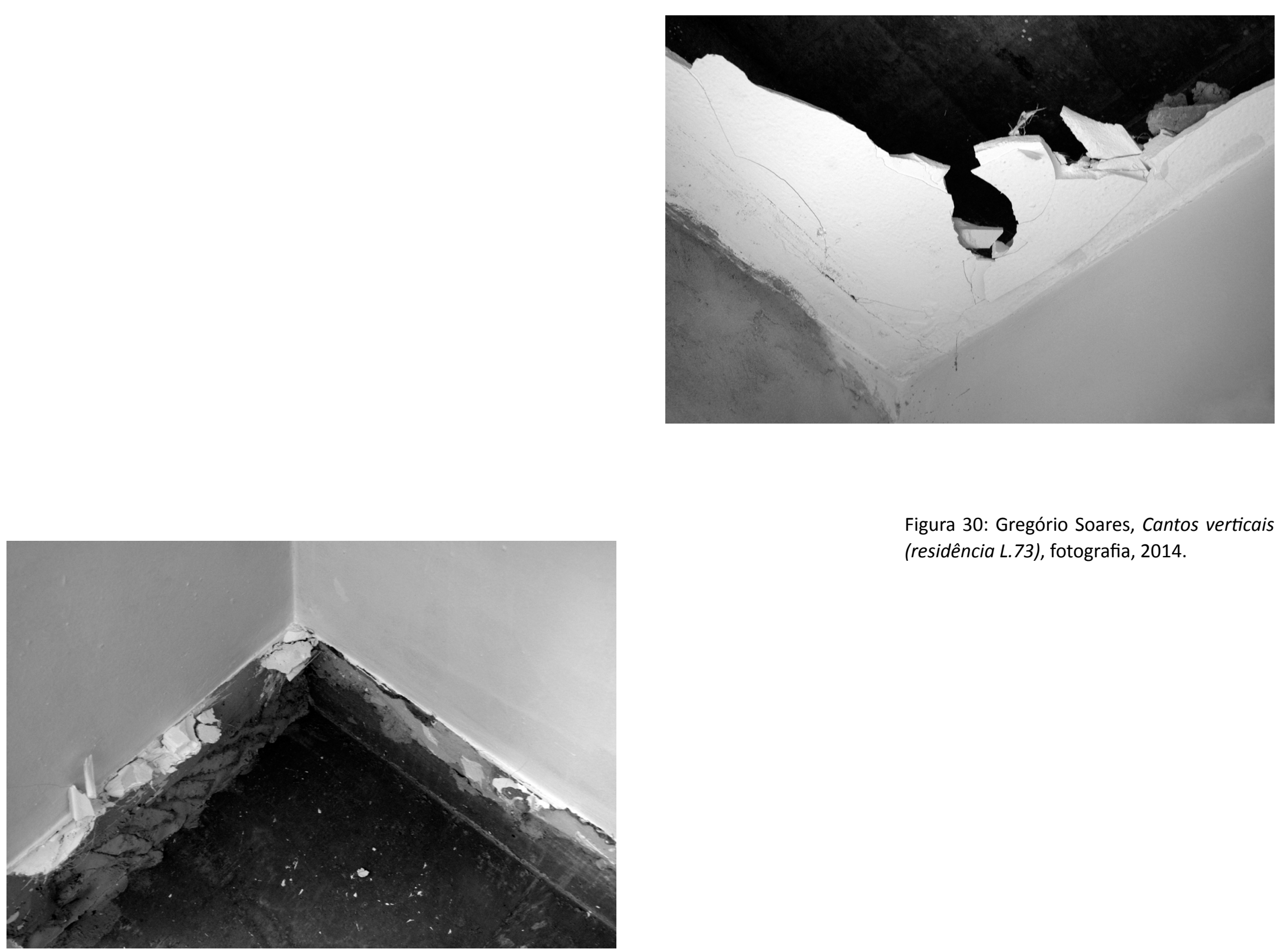

Figura 30: Gregório Soares, Cantos verticais (residência L.73), fotografia, 2014. 
"Mas voltemos a devaneios mais curtos, solicitados pelo detalhe das coisas, por traços do real à primeira vista insignificantes. Quantas vezes não se tem mencionado que Leonardo da Vinci aconselhava os pintores com falta de inspiração diante da natureza a contemplarem com olhos sonhadores as fissuras de uma velha parede? Não haverá um plano de universo nas linhas que o tempo desenha na velha muralha? Quem já não viu, em algumas linhas que aparecem num teto, o mapa do novo continente? O poeta sabe tudo isso. Mas, para expressar à sua maneira o que são esses universos criados pelo acaso nos confins de um desenho e de um devaneio, ele vai habitá-los. Encontra um canto onde permanecer nesse mundo do teto fendido"

Gaston Bachelard, A poética do espaço 
Este "canto", do qual fala Gaston Bachelard, encontrado para viver "nesse mundo do teto fendido", é onde (o lugar que) identifico o meu trabalho. Talvez a possibilidade desta dissertação seja este "canto" encontrado, um lugar para fazer o trabalho "respirar" (ou "parar de respirar", se compreendemos que este movimento dissertativo trata-se de um "arquivamento", de uma "documentação" do trabalho "vivo"), de qualquer forma, fazê-lo "viver" de outra maneira. Fazendo com que tais imagens resistam ao fracasso delas mesmas enquanto discurso (dis-curso: fora do curso, outra direção, digressão, ou desvio), no sentido de que elas, por si mesmas, estão sempre para fora de qualquer direção discursiva, são imagens, são ex-crivisuras. Imagens, ou seja, que dão a ver senão por intermitências, conforme a interessante proposição de sobrevivência das imagens-vagalumes de Georges DidiHuberman:

A imagem se caracteriza por sua intermitência, sua fragilidade, seu intervalo de aparições, de desaparecimentos, de reaparições e de redesaparecimentos incessantes. É, então, uma coisa bem diferente pensar a saída messiânica como imagem (diante da qual não se poderá durante muito tempo mais acalentar ilusões uma vez que ela desaparecerá logo) ou como horizonte (que apela para uma crença unilateral, orientada, apoiada no pensamento de um além permanente, na espera do seu futuro sempre). A imagem é pouca coisa: resto ou fissura (fêlure). Um acidente no tempo que a torna momentaneamente visível ou legível (Didi-Huberman, 2011, p.86-87). 
A possibilidade de tal exercício então, o exercício poético e reflexivo em si, que pretendo, e que tentei demonstrar neste breve relato sobre o processo de excrita sobre os trabalhos, é este que está sempre na iminência, em um tipo de perigo, no limite, no momento prestes a acontecer ou a escapar, por um fio do presente, ou seja, por um triz. Talvez esta possibilidade de dizer pelo fazer, depois de fazer pelo dizer, seja uma forma de testemunho pessoal sobre o estado da matéria de uma imagem, de captura impossível de uma imagem presente, de um autorretrato (no sentido de que é sempre também uma tentativa de compreensão de alguém que diz "eu"), portanto, de um estado da matéria em ruínas, fragmentado, desde sempre, na origem, como propõe Derrida:

O fracasso em recapturar a presença do olhar fora do abismo, onde ele mergulha, não é um acidente ou uma fraqueza, antes figura a própria chance da obra, o espectro do invisível que ela dá a ver sem jamais o apresentar. (...) A ruína não sobrevém como um acidente a um monumento ontem intacto. No começo há a ruína. Ruína é o que acontece aqui à imagem desde o primeiro olhar. Ruína é o autorretrato, este rosto fitado ou desfigurado como memória de si, o que resta ou retorna como um espectro desde que, ao primeiro olhar sobre si lançado, uma figuração eclipsa. (...) Memória pensativa e ruína daquilo que antecipadamente é passado, luto e melancolia, espectro do instante e do estilo de que a própria ponta gostaria de tocar o ponto cego de um olhar que se olha nos olhos, e que não está longe de aí mergulhar até perder a vista por excesso de lucidez (Derrida, 2010, p. 71, 74). 
É então, a partir deste rastro que resta e retorna de uma matéria do presente, senão por um triz, daquilo que escapou e se perdeu em algum momento, onde os sentidos apenas sobrevoam, nunca estáveis, e sobre como esses objetos dialogam com uma experiência poética por meio da foto-grafia em meus trabalhos, é que convido ao terceiro e último movimento desta dissertação onde a pesquisa se confluirá como produto dos dois primeiros capítulos, ligando (ou, emaranhando) as questões da escrita ao problema do tempo (enquanto retorno) em uma produção fotográfica. 
3 Pairar o retorno 


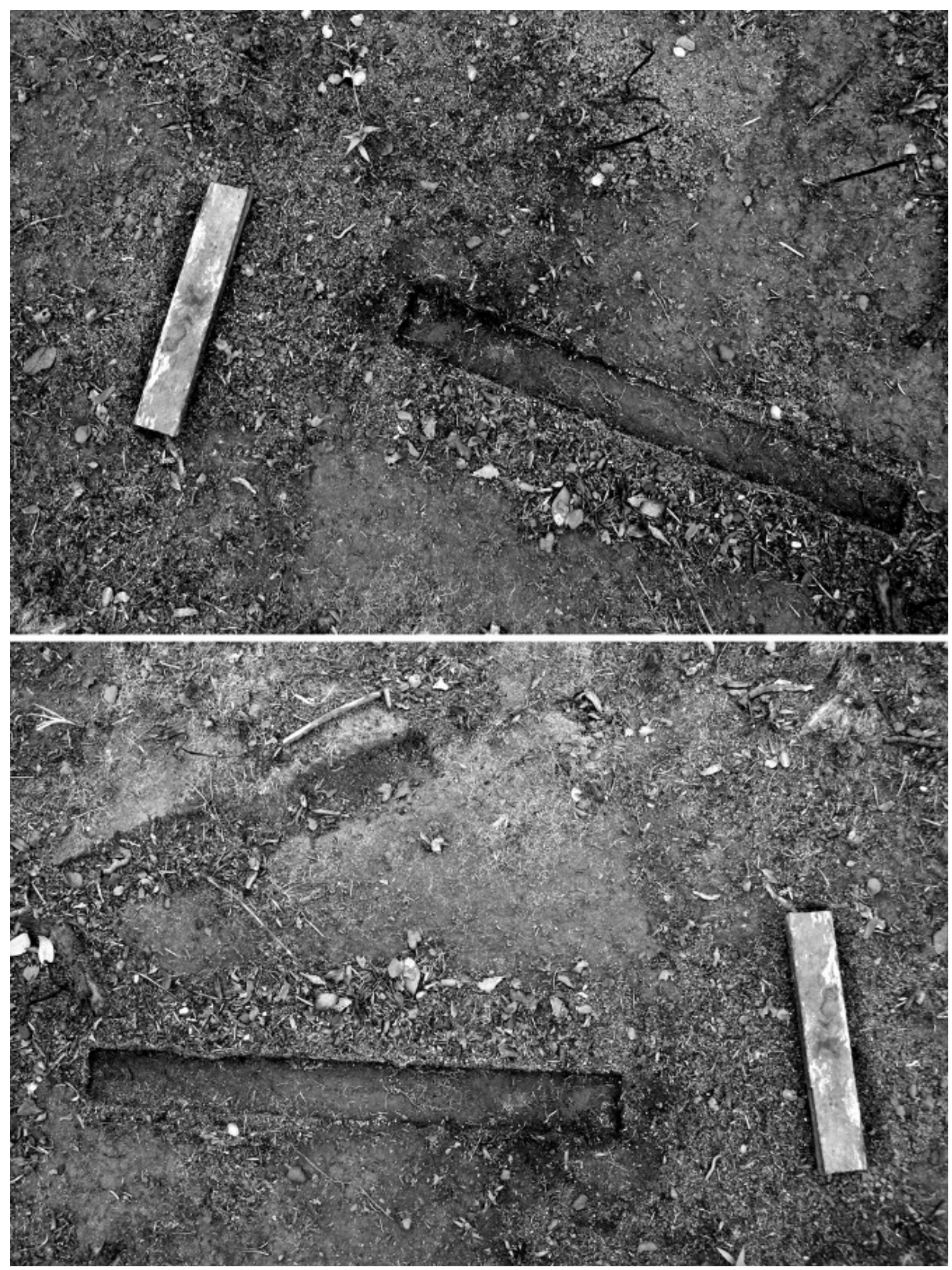

Figura 31: Gregório Soares, Diálogos im/possiveis (diptico III), fotografia, 2011. 

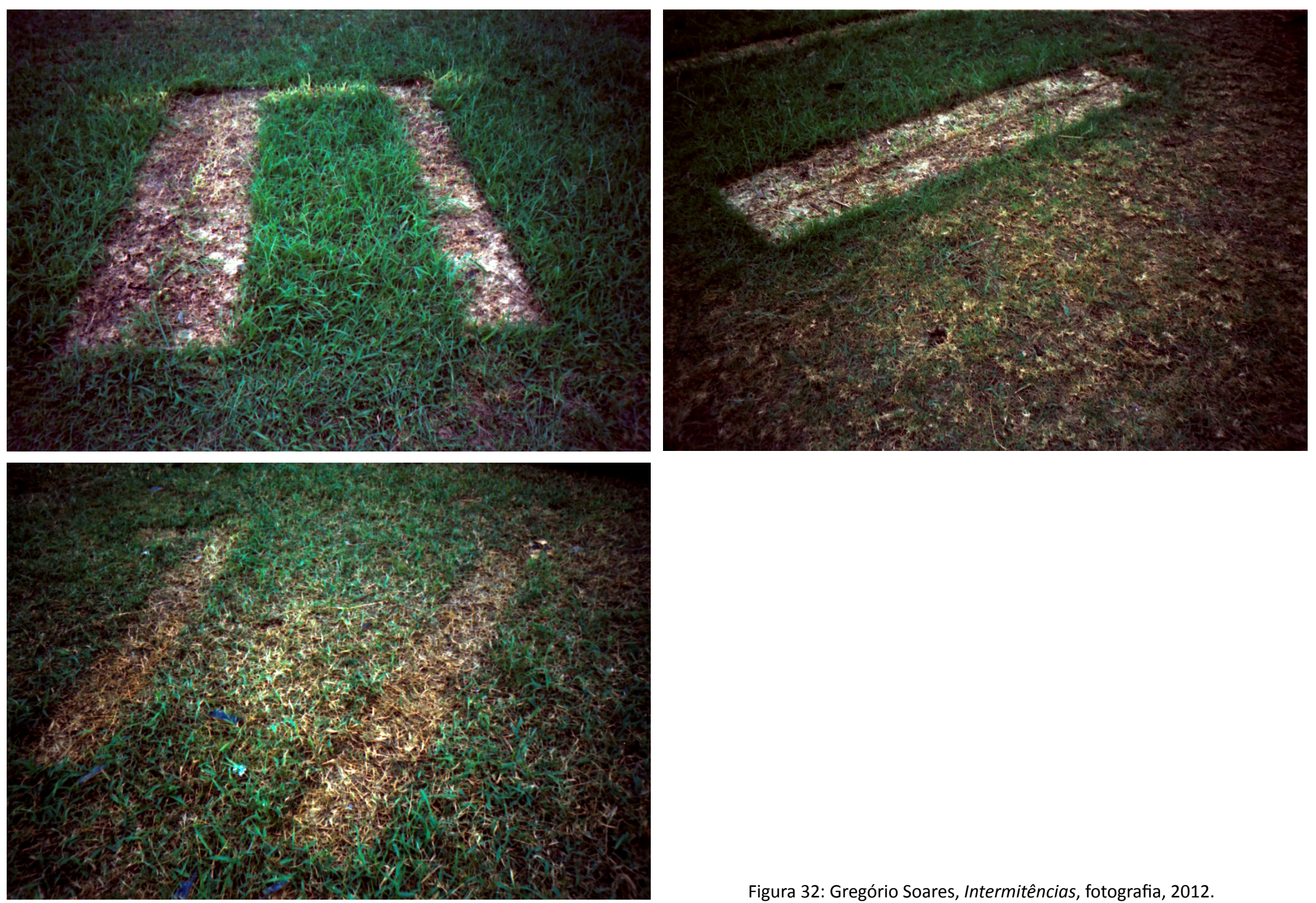

Figura 32: Gregório Soares, Intermitências, fotografia, 2012. 
Figura 33: Gregório Soares, Pairos (detalhe), fotografia, 2012.

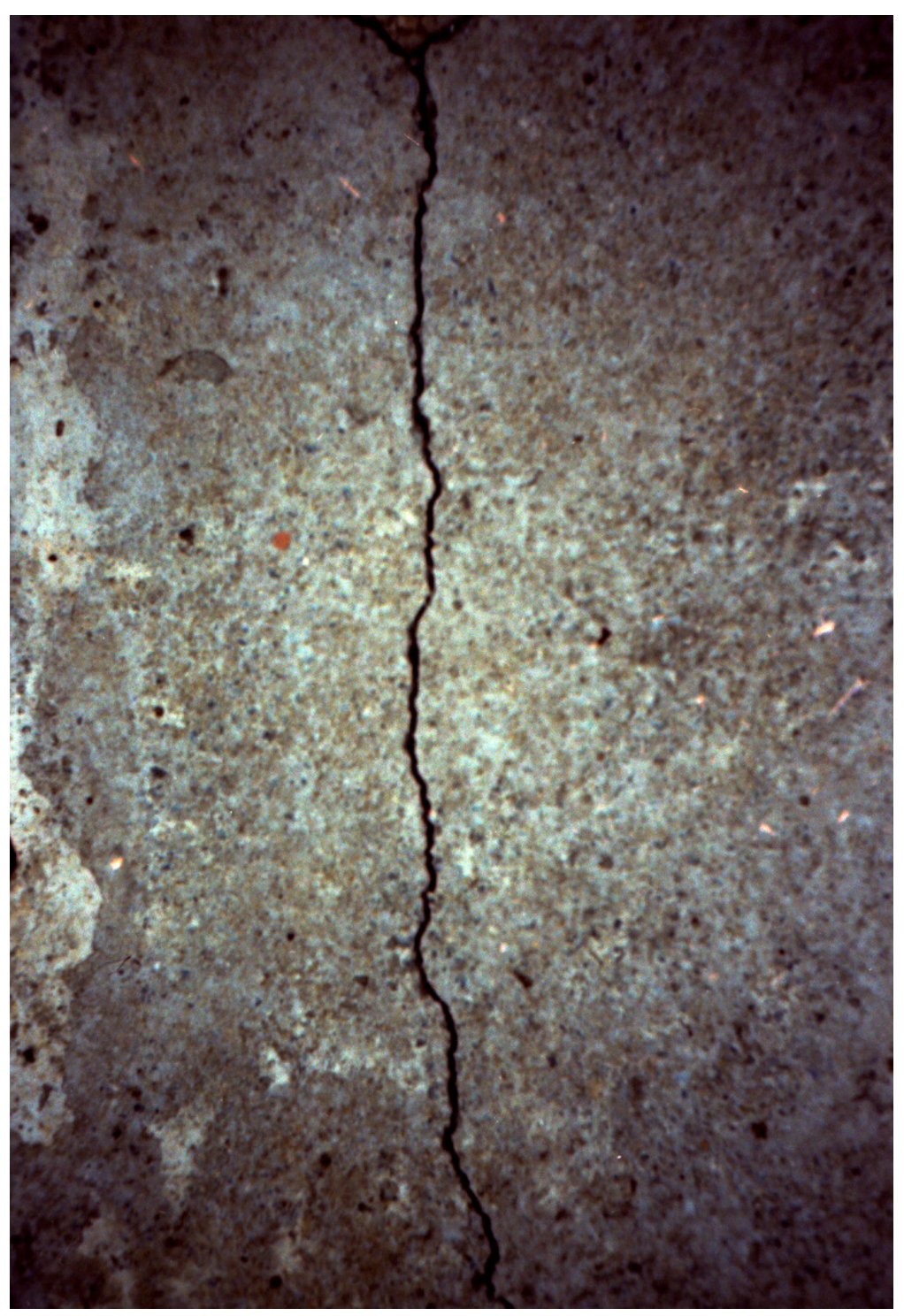




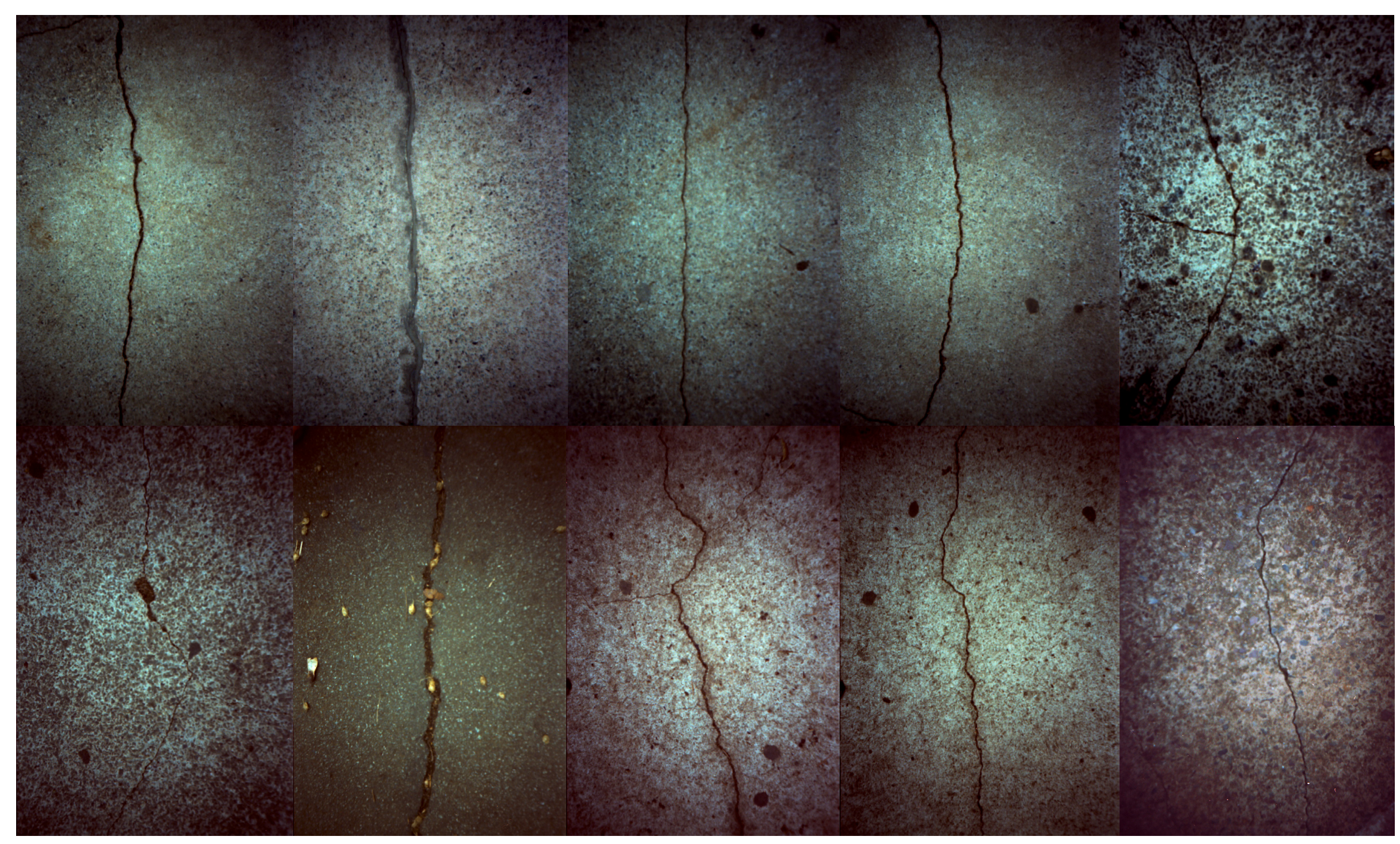

Figura 34: Gregório Soares, Pairos (série), fotografia, 2012. 


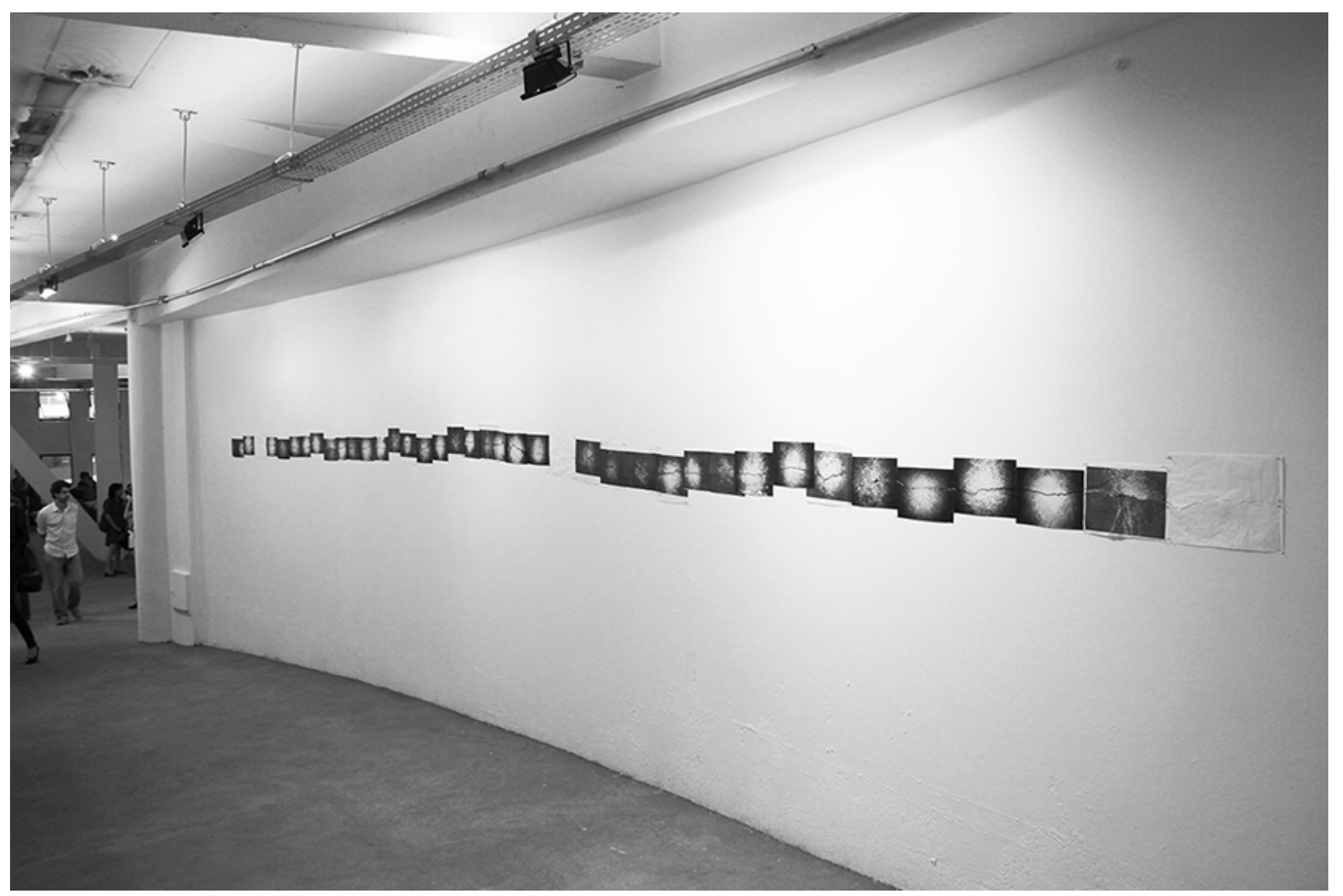

Figura 35: Gregório Soares, Pairos (montagem no Pivô - Edifício Copan, São Paulo), fotografia, 2014. 


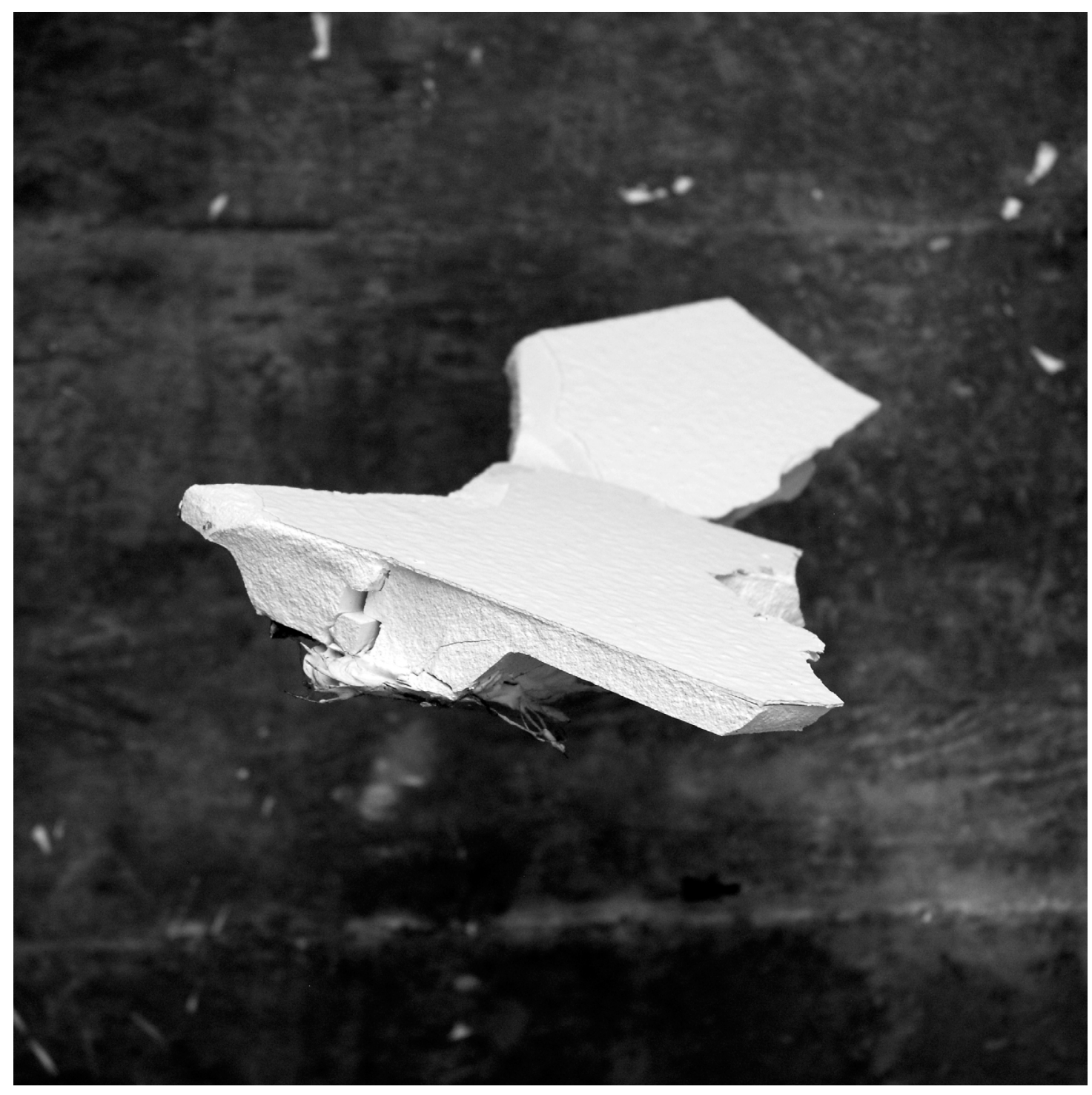

Figura 36: Gregório Soares, Arquipélagos Verticais (detalhe), fotografia, 2014. 


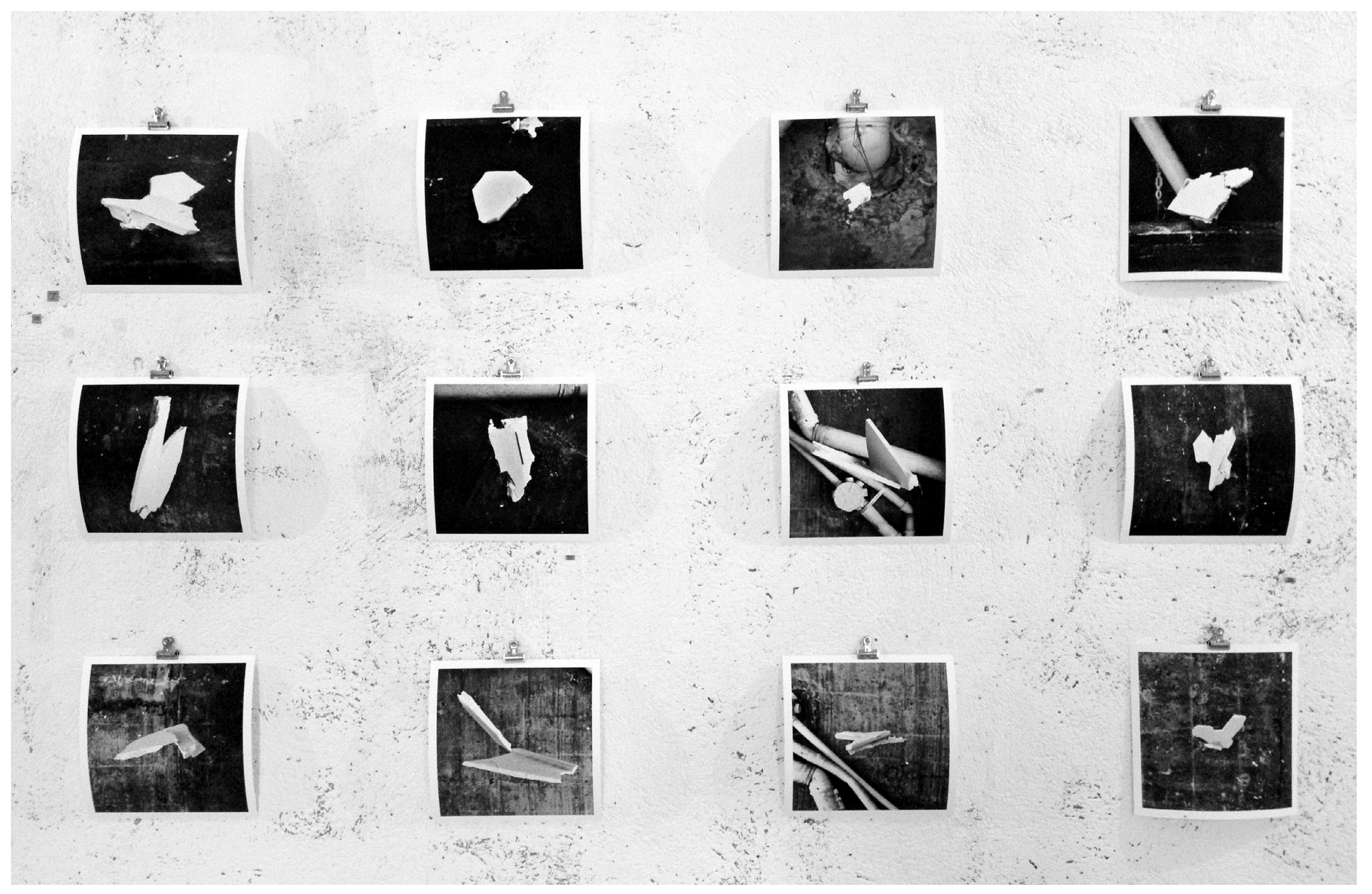

Figura 37: Gregório Soares, Arquipélagos Verticais (série), fotografia, 2014. 
Figura 38: Gregório Soares, Runas-rugas (detalhe), fotografia, 2015.

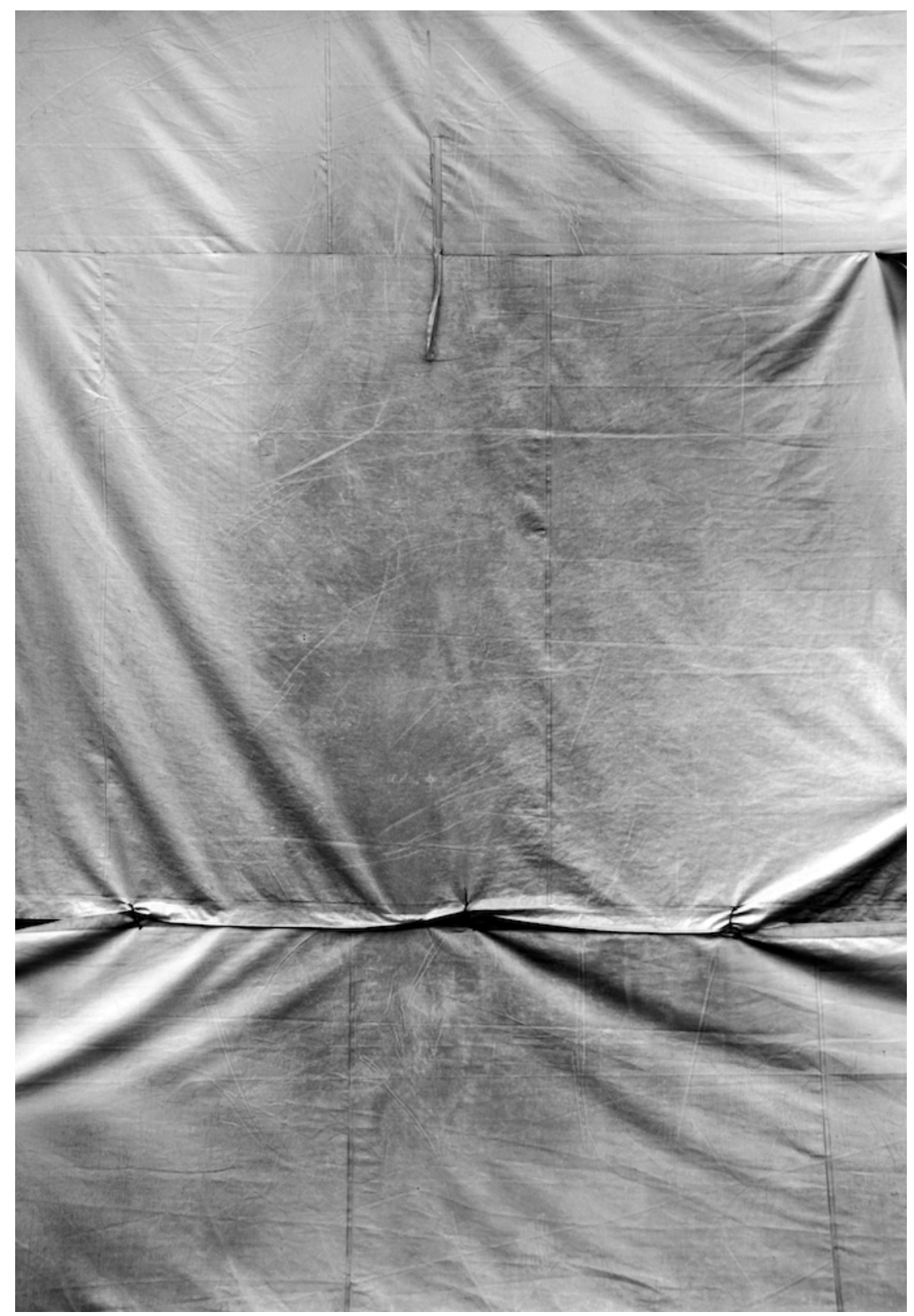




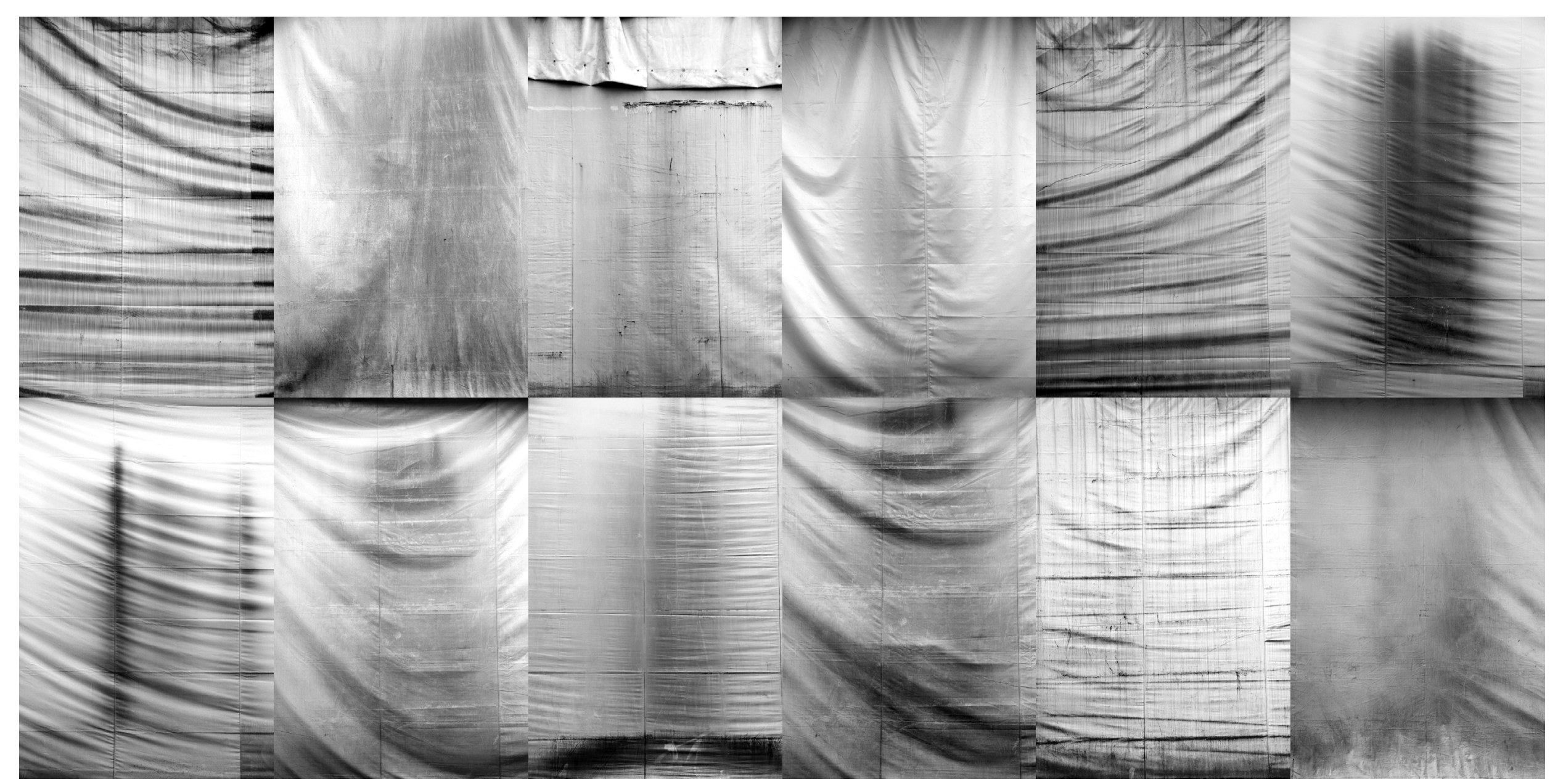

Figura 39: Gregório Soares, Runas-rugas (série), fotografia, 2015. 
3.1 os rastros dos sentidos: uma grafia errante das luzes perdidas

Como o tempo, ainda mais sem corpo, pode trabalhar suas verrumas?

E se o seu corpo é nada

onde é que as dissimula?

Ora, como mais que o vento é oco e sua carne é de nada, é nula,

não agride a paisagem

é de dentro que atua.

João Cabral de Melo Neto, Viagem ao Sahel

Não é que o passado lance sua luz sobre o presente, ou o presente sua luz no passado, mas a imagem é aquilo em que o que se foi se une fulminantemente com o agora em uma constelação.

Walter Benjamin, Passagens

Toda Fotografia é crua, em todos os sentidos da palavra, eis o que tenho de admitir.

Roland Barthes, La Chambre Claire 
A realização deste capítulo último, em linhas gerais, motiva-se tendo como norte e centro os apontamentos dos capítulos anteriores. É precisamente mais uma tentativa de aproximação e identificação de um fazer poético, ou seja, sua escrita, produção e reflexão, mas agora em diálogo com uma possível poiesis fotográfica.

Isto é, compreendê-la, a foto-grafia, essa escrita de luz, por meio dos interesses mapeados por esta dissertação.

Especificamente, os interesses neste capítulo se configuram, em resumo, como um exercício alegórico, de ressonância (estabelecer relações) entre poesia e fotografia, a partir da relação tempo-escrita, mantendo na medida do possível o exercício comparativo entre as propostas anteriores: o problema do desenhodesígnio na escrita-imagem e da matéria no fragmento-ruína (aqui compreendido como esse retorno histórico provocado por toda ruína).

O objetivo central, em outras palavras, é discorrer sobre o modo, de que maneira, com quais interesses, a fotografia está sempre em torno da minha produção, como ela se manifesta e em quais termos. Para isso, o ensaio visual que abre este capítulo, intitulado "pairar o retorno", foi constituído para guiar as reflexões aqui sugeridas, pois são registros de trabalhos que considero constituintes de um campo estritamente fotográfico ${ }^{45}$.

${ }^{45}$ Isto para contrapor aos trabalhos abordados no capítulo anterior, onde são prezados os processos materiais e suas relações com a produção no contexto da arte contemporânea; diferentemente, as séries fotográficas deste capítulo estão inseridas em um campo conceitual mais "tradicional" e, se é possível dizer, "específico" da fotografia, onde os objetivos, mesmo acreditando que possam ser inseridos em uma discussão fotográfica contemporânea, ainda flertam com questões próprias do século $\mathrm{XX}$, baseadas nas discussões do problema da representação da imagem, inseridos na lógica estruturalista do signo, e, talvez, mais pós-estruturalista, do ato e do traço. 
Para demarcar um lugar de fala, segundo as "três práticas (ou três emoções, ou três intenções)", das quais a foto pode ser objeto, propostas por Roland Barthes (1981, p. 23), é possível dizer que me encontro ao mesmo tempo no lugar das três posições: do Operator, o fotógrafo; do Spectator, "o sujeito que olha", no sentido em que pretendo rever, pensar e escrever sobre minhas próprias fotos; restando a terceira, na qual apenas entrevejo-me, a do Spectrum, "o sujeito olhado", "o alvo", aquele que se vê fotografado; no sentido em que sempre me olho, de alguma forma, em meu próprio objeto, ou seja, acontece neste exercício que o objeto se confunde com o sujeito operador; o que poderia ser uma via para recolocar a questão do autorretrato iniciada no capítulo anterior e que pode se estender até o fim dessas reflexões [por exemplo, tomando essas afirmações também de Barthes, como guia: “Porque a Fotografia é o aparecimento do eu próprio como outro, uma dissociação artificiosa da consciência de identidade" (p. 28). E: "a Fotografia (...) representa esse momento deveras sutil em que, a bem dizer, não sou nem um sujeito nem um objeto, mas essencialmente um sujeito que sente que se transforma em objeto (...)" (p. 30)]. 

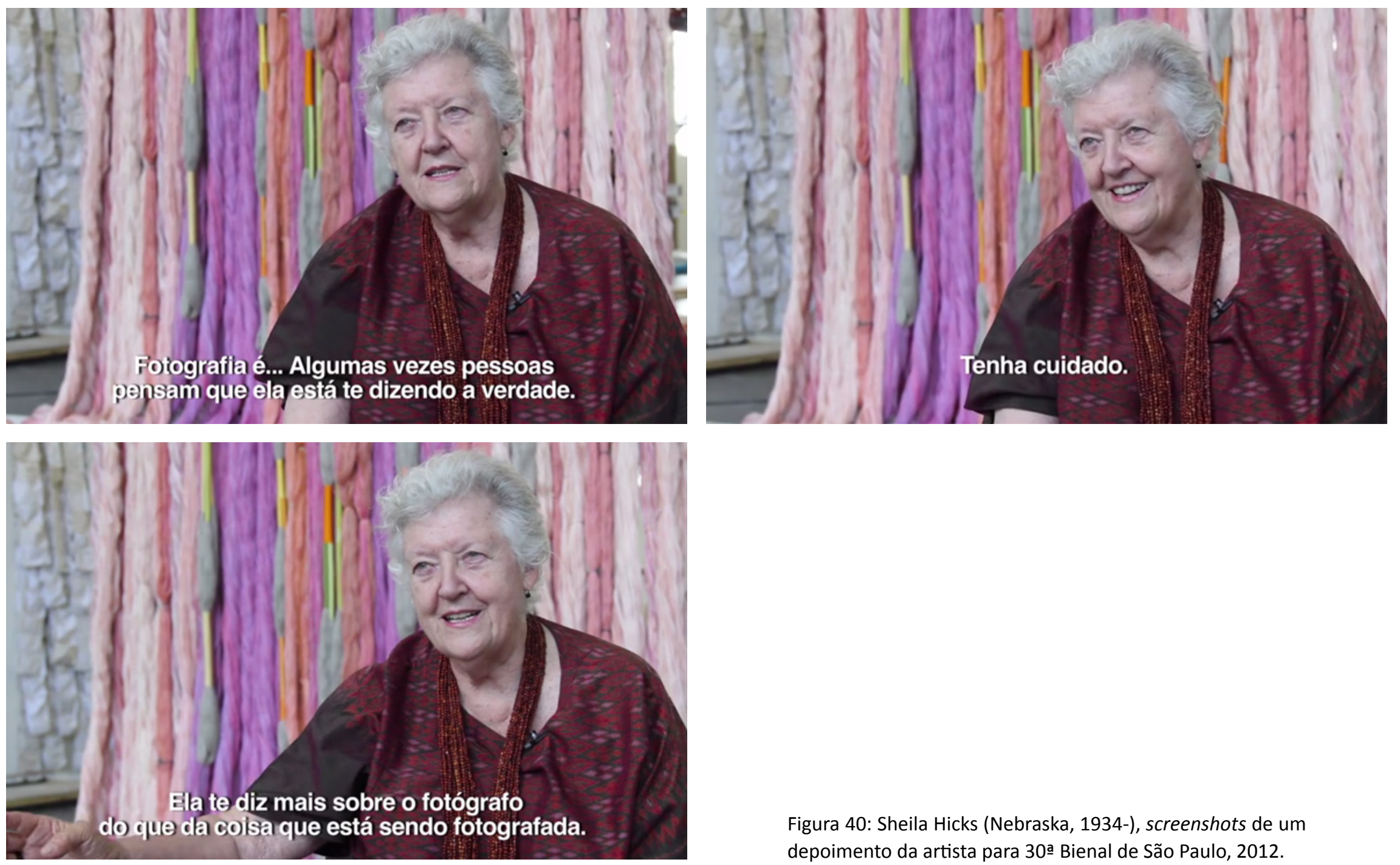

Figura 40: Sheila Hicks (Nebraska, 1934-), screenshots de um depoimento da artista para 30a Bienal de São Paulo, 2012. 
É certo que para que se possa escrever sobre qualquer tema é sempre preciso fazer uma circunscrição das abordagens conceituais das quais se lançará mão. Porém, no caso da fotografia como tema essa necessidade parece se acentuar. Isto para não incorrer nos riscos de escrever por cima do já escrito tantas vezes ou escrever (resumidamente) um pouco do tudo escrito: não é exagero afirmar que muito se escreve sobre o tema fotográfico, desde o final do século $X X$ até os dias atuais, em suas diversas implicações e limitações concretas ou metafísicas. Portanto, no caso específico desta pesquisa, tentarei me concentrar em apenas anotar (comparando com outras anotações, de outros artistas e autores) os interesses que o gesto fotográfico tem em um recorte da minha produção, perpassando por dois principais pontos: 1) um problema de tempo, que compreende o ato fotográfico (Dubois, 2012) como um "corte temporal", ou seja, como algum acontecimento que sempre propõe um redesenho do tempo; (e, novamente) 2 ) um problema de escrita (e também de desenho), enquanto proposição de uma lume-grafia, que já estabelece uma questão de um "saber", um vir à luz, um dar a ver, um ver por meio da escrita de/da luz, de outro modo, uma questão (filosófica ${ }^{46}$ ) de "sentido" e "verdade" da fotografia e suas possíveis implicações para uma produção poética reflexiva.

\footnotetext{
${ }^{46}$ Apesar das pretensões filosóficas dos meus interesses é preciso repontuar que falo/escrevo, aqui, sempre do ponto de vista de uma práxis poética, de uma escrita de "artista-pesquisador", bem como a pergunta por sua possibilidade, na qual estão sempre em jogo os objetivos e as especificidades da linha de pesquisa onde esta dissertação se insere, mesmo que em diálogo (inevitável e dentro das minhas possibilidades) com outras áreas de pesquisa, bem como a inter-relação entre Arte, Filosofia e (também, de alguma maneira) História.
} 
Tendo, então, esta dissertação como objeto para pensar um outro objeto presente (estes trabalhos propostos por mim mesmo) é possível começar dizendo que tal interesse do tempo é já um conceito pressuposto por esta prática (necessária) de retornar aos meus próprios trabalhos, já realizados em um passado recente. De fato, este é um exercício de recuperação, tentativa de "trazer de volta" um acontecimento e uma experiência (vale perguntar, já que é um exercício de memória, se não é também um exercício de recriação). Assim, talvez as perguntas essenciais deste intento podem ser: o que está em jogo neste exercício de retorno? É possível retornar uma experiência e reconstituí-la? Se os trabalhos propostos, em suas ocasiões, necessárias, oportunas ${ }^{47}$ e urgentes, estão sempre atentos e levam em conta os contextos específicos de sua realização, como trazer em testemunho suas presenças para estas linhas de palavras e imagens e para estas páginas de estruturas circunscritas no espaço de um retângulo branco? Qual o papel da fotografia sobre a reflexão sobre o tempo? Estas questões me parecem permitir já entrever muitos dos problemas que estão em jogo na práxis poética em que me encontro.

Este uso do retorno, que abarca o "retorno" enquanto objeto teórico, já foi e ainda é utilizado por muitos autores dentre filósofos ${ }^{48}$ e teóricos da arte.

47 Em outras palavras seria a formulação de uma pergunta do kairós (para os gregos: tempo qualitativo, indeterminado) para o chronos (tempo passível de ser quantificado, sequencial e linear, cronológico).

${ }^{48}$ Ver p.e. Giorgio Agamben sobre $O$ eterno retorno em F. Nietzsche: “A imagem Memorial”, em $A$ potência do Pensamento: Ensaios e Conferências, 2015, p. 291. 
Para exemplificar tal manejo dentro de uma tentativa de compreensão das (neo-) vanguardas artísticas, este exercício, de entendimento, que se dá sempre após um acontecimento, pode ser observado também dentro da proposição do conceito de a posteriori, formulado por Hal Foster em seu livro O retorno do Real99 (2014). Para o autor, teórico e crítico, "O efeito a posteriori" (p. 44-49), funciona como uma alternativa para uma narrativa que intenta compreender um determinado projeto artístico, bem como seu desenvolvimento, sem recorrer aos "termos historicistas", ou seja, "em termos de evolução e progressão" ou "em termos de involução e regressão". Sua alternativa, em linhas gerais, apenas para marcar, recorre ao modelo de sujeito psicanalítico. Assim, para tal sujeito, "a subjetividade não se estabelece de uma vez por todas; ela é estruturada como uma alternância de antecipações e reconstruções de eventos traumáticos". E tal evento, por fim, propõe Foster:

só é registrado por meio de outro que o recodifica; só chegamos a ser quem somos no efeito a posteriori (...) como um processo contínuo de protensão e retensão, uma complexa alternância de futuros antecipados e passados reconstruídos - em suma, num efeito a posteriori que descarta qualquer esquema simples de antes e depois, causa e efeito, origem e repetição (p. 46).

${ }^{49}$ Título original: The return of the Real: the Avant-Garde at the End of the Century, 1996. 
Claro que, para o contexto presente, tal modelo teórico apenas sobrevoa as expectativas, que são menores. Mas, não deixa de operar na medida em que a tarefa proposta impõe questões que envolvem uma temporalidade narrativa e textual (isto é: histórica); ou seja, obriga-me a pensar as questões do tempo e do texto em um projeto poético contemporâneo.

Estruturalmente este capítulo será um composto dos dois anteriores, também recorrendo a uma construção fragmentária, intercalando uma escrita reflexiva, dialógica e referencial, lançando mão de imagens de estudos e processos pessoais a serviço dos trabalhos apresentados no ensaio visual introdutório (mesmo que sem propor uma reflexão crítica e experiencial dos processos de cada trabalho, como feito anteriormente; e sim, a reflexão de problemas gerais, que são recorrentes, como um traço comum). No processo de intercalação entre escrita verbal e imagética (imagens e poemas referenciais) recorrerei, no limite, à construção por montagem, empenhando em uma relação analógica ${ }^{50}$.

${ }^{50}$ Relação de semelhança entre dessemelhanças; tendo em vista uma provocação para a problemática do termo em uma crítica fotográfica. 
Mas, para um pouco além, como proposição específica, o caráter fragmentário aqui terá outra referência, a saber: a própria fotografia. Pretenderei, novamente, que os objetivos deste capítulo se confundam com o próprio objeto. $\mathrm{O}$ texto, discursivo, verbal, se estruturará como se fosse, metaforicamente, "disparos" fotográficos, "flashes", "relâmpagos", reflexões em reflexos, como aqueles que por frações de segundos passam pelo obturador de uma câmera foto-gráfica, grafando o negativo. O "negativo" aqui é o "positivo" da folha em branco ${ }^{51}$. O "obturador" passa a ser as aberturas intermitentes que meu pensamento tenta encontrar em meu corpo para se expor, revelando-se como riscos nestas páginas sensíveis ao toque. Uma escrita porosa, portanto, pelos poros; e, ainda assim, e por isso mesmo, aporética. Uma escrita do retorno.

Daí que essa grafia (das luzes perdidas) é errante, novamente fundamentada no desvio, previsto na introdução, pois busca encontrar algo sem antes saber o que é, mas que desconfia ser anterior ao acontecimento da questão. Busca-se para saber. É um pressuposto, talvez, de toda pesquisa. Buscar, pela escrita, no sentido que Maurice Blanchot sugere, como "a questão a mais profunda":

A questão a mais profunda é esta experiência do desvio no modo de um questionamento anterior ou estranho, ou posterior a toda questão.

51 Vale notar que escrevo originalmente em um programa de computador; portanto, escrevo (virtualmente) sobre uma tela de luz, e cada letra, obscurecida, não é senão um negativo na tela iluminada, ou seja, um processo inverso do processo analógico fotográfico, mas também dependente de uma fonte de luz (neste caso, uma fonte artificial). 
O homem, pelo viés da questão profunda, é direcionado para aquilo que desvia - e se desvia.

(...)

A busca seria então da mesma espécie que o erro. Errar é voltar e retornar, abandonar-se à magia do desvio. O descaminhado, aquele que saiu da proteção do centro, gira em torno de si mesmo, entregue ao centro e não mais cuidado por ele (Blanchot, 2010, p. 60, 64).

É importante indicar, então, como recomendação, que sempre onde houver uma proposição de "escrita", neste capítulo, estarei de algum modo tentando buscar/ pensar/retornar sobre a escrita da foto e da escrita a partir da foto, aquilo que se escreve dela. Sendo então uma escrita da escrita: ex-crita, logo meta-escrita ${ }^{52}$. Uma escrita que tem como objetivo pensar o tempo no processo fotográfico em minha pesquisa, que sempre me escapa, que nunca decifro, que nunca apreendo por completo. É, então, um não-saber que provoca esta tarefa. É por compreender, de antemão e por fim, que o problema da fotografia é, para esta pesquisa, como um beco-sem-saída. É, mais ainda, uma busca, como tentarei mostrar, por alguma coisa que não perdi.

${ }^{52}$ No sentido proposto por Vilém Flusser, em “Metaescrita”, 2010, p. 19-23. 
Sabedor de minha curiosidade incurável, meu pai, desde a infância, sempre que me observa aparentemente "perdido", empenhado em alguma tarefa sem objetivos claros, habituou-se em me perguntar advertindo: "está procurando o que não perdeu?"

Pode-se dizer que muitas vezes parece existir uma ideia (comum, no sentido corriqueiro da palavra) que tematiza os artistas e poetas como aqueles que estão sempre atentos ao tempo presente. Ou, de outro modo, ainda mais trivial, que possuem "antenas" e, em algum momento, conseguiram prever questões não percebidas até então; que são, assim, "fora" de seu tempo, vivem em um tempo a frente (o que já contrariaria uma noção de contemporaneidade, tão almejada nos dias atuais). Talvez os mesmos pensamentos podem se confirmar quando algum estudo crítico e histórico demonstra (por uma construção do retorno) o quanto determinados artistas anteciparam problemas fundamentais de seu tempo (em vida).

Alguns exemplos poderiam confirmar essas "previsões" especulativas, bem como discussões neste sentido. Jasper Johns em seu breve texto sobre "Marcel 
Duchamp (1887-1968)", de alguma forma contribui para essa percepção, quando lembrou: "Ele disse que estava à frente de seu tempo. É possível adivinhar uma certa solidão ali" (Johns in Ferreira e Cotrim, 2006, p. 203), como um presságio (neste caso, como tantos outros, tendo em vista o projeto artístico em vista) do próprio Marcel Duchamp. E, conclui Johns: “A comunidade artística sente a presença de Duchamp, e sua ausência. Ele mudou a condição de se estar aqui" (p. 204). Neste caso, a obra do artista é seu legado como um todo, todo seu pensamento em vida, permanecendo enquanto proposta, enquanto uma sugestão de um desenho, de um desígnio para a arte contemporânea.

De modo semelhante, em um tempo posterior a Duchamp, Robert Smithson aponta para a mesma recorrente problemática, de diversas maneiras cito-o:

A existência do artista no tempo vale tanto quanto o produto final.

(...)

Artistas com uma visão fraca do tempo são facilmente enganados por esse tipo de crítica que vitimiza, e são seduzidos para alguma história trivial. Um artista só é escravizado pelo tempo se o tempo for controlado por alguém ou por alguma coisa que não ele próprio.

E conclui com uma questão-chave:

Muitos gostariam de esquecer o tempo por inteiro, porque este oculta o "princípio de morte" (todo artista autêntico sabe disso) (Smithson in Ferreira e Cotrim, 2006, p.197). 
Este "princípio de morte" talvez seja o grande pesadelo dos artistas (isto é, potencialmente qualquer ser humano) em relação à sua obra: cair no esquecimento. Tal é o compromisso de "compreender o tempo" e não deixar ser "enganado" por ele: criar dispositivos, estratégias, que minimizem o impacto da morte, ou seja, o desaparecimento de si e do resultado de si, assegurando, assim, uma continuidade histórica.

Seria possível fazer um resumo sem fim da história da arte, da poesia e da cultura apenas pela temática da morte. Das múmias encontradas em diversas partes do mundo, datadas de mais de 5.000 a.C., à temática das Vanitas ao longo dos séculos XVII ao XVIII, é isto que se está em questão. Na contemporaneidade o problema não é diferente e é recorrente o retorno das mesmas questões ${ }^{53}$.

É neste sentido também (contra e para a morte), por exemplo, que o filósofo russo-alemão Boris Groys (1947) desenvolve sua ideia de políticas da imortalidade, ponto chave em seu pensamento, que supõe: "esforço consciente de formulação, conservação e institucionalização de procedimentos de intervenção no campo cultural" (Groys apud Pécora, 2008, p. 2). Para ele, ironicamente até, há uma "competição" no âmbito da cultura, dos vivos entre si e com os mortos, por um desejo de superação, de conquista de um lugar eterno para a individualidade (onde se encontram, no mesmo fluxo, artistas e pensadores).

${ }^{53}$ Ver p.e. Kátia Canton, Natureza-morta/still life. São Paulo: MAC USP/Sesi, 2004; E Anne-Marie Charbonneaux. Les vanités dans l'art contemporain. Paris: Flammarion, 2010. 
Ou seja, para conquistar o próprio "lugar", como outros conquistaram, é preciso superar as expectativas históricas. "Os mortos", assim, "vivem representados por suas obras, imagens, teorias, atitudes, linguagens". Nas palavras fúnebres de Groys, esta tarefa, portanto, de "entrar da tradição", pode ser nomeada como "projetar a própria tumba" ou "fabricar o próprio cadáver". Isto significa, para o autor, em linhas gerais, que não há lugar para artistas e pensadores frágeis e sensíveis que se recusam a aderir à difícil tarefa (política, prática) de construir as próprias condições que contrariam a sua efemeridade.

Este exercício de uma certa "manutenção" da vida da obra (no sentido amplo, do resultado de um trabalho) no tempo (da história), que é apenas um entre tantos possíveis na problemática sobre o tempo, pode-se dizer que acompanha os artistas ao longo do século XX em muitas frentes, sendo duas: na fotografia e na escrita. Por um lado, o aumento significativo de "escritos de artistas", desde os manifestos de vanguarda às proposições teóricas das décadas de 60 e 70. Por outro, a recorrente questão do estatuto da fotografia alternando entre documento e coeficiente artístico.

Este contexto é que torna possível uma nova abordagem temporal na produção artística, com foco no "presente", advinda das novas formas de apropriações e reproduções técnicas dos dispositivos de registros de imagens, onde o "processo" da obra passa a ser a questão central. Por exemplo, é isso que pensa da Costa, no texto "Uma questão de registro": 
O foco da estratégia artística se tornou o presente. (...) O tempo vivo, em vez da representação, é o que passa a importar aos artistas. (...) Com a obra-evento, portanto, apareceu um elemento inesperado na prática artística: o acúmulo de fragmentos e restos das intervenções, a sobra de elementos materiais de ações, performances e instalações. Restariam também fotografias, filmes e, mais tarde, vídeos que documentam eventos e ações dos artistas (da Costa, 2009, p. 19, 21).

A noção de "documento" então passa a ser colocada em cheque, pois está sempre passível de ser reprocessada, revisada, permanece enquanto potência processual ${ }^{54}$ e virtual, bem como amplia o espaço de circulação das obras para além dos espaços de galerias e museus (como festivais de cinema, livrarias, espaços não institucionais etc.).

O que permanece em jogo, ainda sim, o que retorna, portanto, com os novos processos de registro, é seu valor de origem, de propriedade, ou seja, seu valor ontológico. E é dessa forma que se pergunta ainda da Costa, em seu texto:

A imagem-documento elucida o modo crítico da arte contemporânea, isto é, a arte que visa e reflete não uma linguagem e seu sistema formal, mas sim a condição que permite sua própria existência. (...)

54 Sobre uma discussão do "processo" remeto ao trabalho de Cristina Freire, Poéticas do processo: arte conceitual no museu. São Paulo: Iluminuras, 1999. 
Não estaria o registro, no espaço da experiência estético-poética contemporânea, conformando um problema filosófico: a possibilidade de um evento passar e, ao mesmo tempo, permanecer? (da Costa, 2009, p. 30)

É neste sentido que as questões "as mais profundas", fundamentais, de fundo, das quais esta dissertação é veículo de busca, re-voltam, re-tornam. É neste contexto que a fotografia, enquanto escrita (de luz), é questionada no processo dos meus trabalhos. $O$ que antes é apenas pauta de registro (como em alguns trabalhos apresentados no capítulo anterior), uma certa necessidade de suprir o medo da perda do processo e do resultado dos trabalhos, ele mesmo, depois, o resultado do registro, torna-se um problema. Não mais enquanto representação de um fato ocorrido, mas enquanto apresentação dos próprios problemas.

A partir dessas questões que comecei a buscar (quero dizer, fotografarfotogravar) "isto" que estava sempre se tornando presente, recorrente, intermitentemente, que desconheço a priori e sempre me espanta. Passei a fotogravar, então, o que sempre me abisma; o que por um grau de ausência, de falta, quando parece parado no tempo, quando parece que algo se perdeu, algo 
morreu $^{55}$, por muito tempo, que só se mostra (por um não mostrar), no esticar do tempo, no pairar do tempo, é que me interessa escrever uma foto.

Se fosse possível fazer uma própria definição (indefinida) sobre o gesto de fotografar, esta seria: procurar o que se perdeu sem saber o que é.

"Tirar uma foto": sempre me pergunto porque utilizamos este verbo para dizer que fizemos uma fotografia. Seria apenas um modo comum de compreensão de que algo é "capturado" naquele momento? Mas a captura, neste caso, necessariamente tem algo em comum com o tirar? O que seria este "algo"? O que tirar-se-ia? E, se algo saísse (de cena), no ato de retirar, o que restaria do resto?

\footnotetext{
${ }^{55}$ Sobre um dos sentidos de morte provocados pela fotografia, recorro como exemplo, a um de Susan Sontag: "Todas as fotografias são memento mori. Fazer uma fotografia é participar de uma mortalidade, vulnerabilidade, mutabilidade de outra pessoa ou coisa. Precisamente porque seccionam um momento e o congelam, todas as fotografias atestam a impiedosa dissolução do tempo" (Sontag, 2006, p. 32 [tradução minha da versão em espanhol]).
} 
como rasurar a paisagem

a fotografia

é um tempo morto

fictício retorno à simetria

secreto desejo do poema

censura impossivel

do poeta

Ana Cristina César, Rio de Janeiro, 1952 - 1983

(em Poética, 2013) 
Penso sobre o sedutor funcionar mecânico do obturador da câmera fotográfica, que permite a imagem refletir, que é, ao mesmo tempo: um desvio de direção, o transparecer de uma percepção, aquilo que permite a luz passar (no tempo preciso) e também, pensar ${ }^{56}$, meditar, e, ainda, recurvar, vergar (do grego reflexi, reflexum).

Assim, tanto no princípio da camera obscurae, como na origem do processo da visão, há sempre uma anamorfose, é sempre uma perspectiva do objeto no sujeito, e o inverso, que suspende e distorce o efeito da temporalidade e da representação da imagem. A imagem se inverte no negativo. E é interessante pensar sobre esse negativo da imagem como in-versão, como uma versão interior. No fundo (literalmente, da caixa preta ${ }^{57}$ ), no mais profundo (no pensamento), internamente, sempre há uma possibilidade contrária, inversa, agindo na construção da imagem fotográfica. Ou seja, ela parece se permitir sempre, no mínimo, uma dupla possibilidade (dialética?). O que estou tentando propor é a possibilidade desse caráter agir como sintoma de uma imagem fotográfica pensativa, como sugere Barthes (1981, p. 61).

\footnotetext{
56 “No fundo, a Fotografia é subversiva não quando assusta, perturba ou até estigmatiza, mas quando é pensativa" (Barthes, 1981, p. 61).

${ }^{57}$ Para remeter ao interessante pensamento de Vilém Flusser, no qual a questão fundamental gira em torno do próprio aparelho (ou aparato) fotográfico: "brinquedo que traduz pensamento conceitual
} em fotografias" (Flusser, 2011 p. 17). 
Assim, parece também que neste fator mecânico, físico e concreto, há uma resistência contra uma ideia de pureza preexistente na imagem, contra aquilo que diz simplesmente "ser o que é". Esse duplo, esse mínimo duplo comum da imagem fotográfica, não indicaria que o "ser" da imagem é sempre mais que si?

Do processo interno à ex-posição, ex-por: saída de si. A saída é um processo contínuo. É um caminho, não um fim. É manter-se entre o dentro e o fora. É ver e apontar, triscar o fora. É uma experiência: "ex-per-ientia, um 'provir-de e um iratravés de"' (Agamben, 2005, p. 43).

O "não importa o quê" torna-se então o cúmulo sofisticado do valor (Brathes, 1981, p. 56).

Diferentemente dos meus trabalhos mais construtivos (vide capítulo anterior), concentrados em um problema da matéria, ao contrário, quando estou imerso em trabalhos fotográficos, fico sempre muito pouco (ou nada) consciente 
do meu objeto. Quero dizer, procuro fotografar coisas que praticamente não sei nada sobre elas, que não me comunicam "nada" a princípio. Sendo este "nada" já alguma coisa, portanto contraditório, mas que parece estar sempre em potência de "dizer" outra coisa, sempre em um estado de possibilidade. E o processo de reconhecimento (que pode ocorrer em diferentes momentos: muito depois ou ainda não ter ocorrido), ou, o que minhas fotos teriam a me "dizer", só inicia a posteriori (Foster, 2014, p. 44), normalmente quando começam a constituir um corpus, um conjunto, um ensaio, e como que construir dis-cursus ${ }^{58}$, entre si, independente de qualquer objetivo a priori. De outro modo, é dizer que, simplesmente, é a foto que me diz dela, é ela que se escreve. Por isso a necessidade de retornar a ela sempre, a cada vez.

A essência profunda e eterna do homem é constituída por impulsos vindos de uma infância tornada pré-histórica. É isso que o poeta quer despertar em seus ouvintes.

Sigmund Freud, A Interpretação dos Sonhos

${ }^{58}$ Segundo a proposição de Maurice Blanchot sobre o discurso de Pascal: “(...) mas seu discurso, por intermédio da dupla dissidência do pensamento e da morte, manifesta-se como dis-cursus, curso desunido e interrompido que, pela primeira vez, impõe a ideia de fragmento como coerência"; em "O pensamento e a exigência de descontinuidade", A conversa infinita 1, 2010, p. 30, grifo meu. 
Esse princípio de "desinteresse" no objeto me faz acreditar que quando fotografo tenho a impressão de que retorno à infância. Reconecto-me com uma despreocupação (e uma despretensão) que só me recordo igual na infância. Pensando sobre isso, enquanto escrevo, lembrei-me (retornei-me) de uma prática que perdurou até a metade da minha adolescência, absolutamente despretensiosa: "andar" de bicicleta, sem destino, sozinho. Não havia objetivo, nada que fosse anterior ao desejo de sair "andando". Não havia "quê" nem "porquê". Havia apenas o "ir" e o "chegar" em algum "lugar nenhum" (desconhecido), onde eu pudesse sentir a sensação do "sumir". Sumir-me. Ver-me no risco de desaparecer, no lugar sem referência. E, para em seguida, depois dessa "conquista" do estranho, retornar. Recuperar a referência perdida por alguns instantes. Essa é a experiência que pretendo voltar, rever, a cada vez, com a fotografia, hoje, no presente (e pretenso) "adulto" 59 falante ${ }^{60}$ e pensante: manter-me nesse ir-e-vir-limite do "saber" e do "não-saber", do "ver" e do "não-ver"61.

59 Para uma abordagem sobre a imagem na arte contemporânea e infância remeto ao trabalho de Matias Monteiro, Infans: (im)pertinências do infantil na imagem, Brasília: Programa de PósGraduação em Arte, Instituto de Artes, Universidade de Brasília, 2008.

60 Para uma reflexão da voz e da experiência da língua em relação à infância, assim como para uma filosofia dos limites da linguagem, ver G. Agamben: “Um experimentum linguae deste tipo é a infância, na qual os limites da linguagem não são buscados fora da linguagem, na direção de sua referência, mas em uma experiência da linguagem como tal, na sua pura autorreferencialidade" (2005, p. 12).

${ }^{61}$ Referência às palavras francesas "savoir" (saber) e "voir" (ver). 


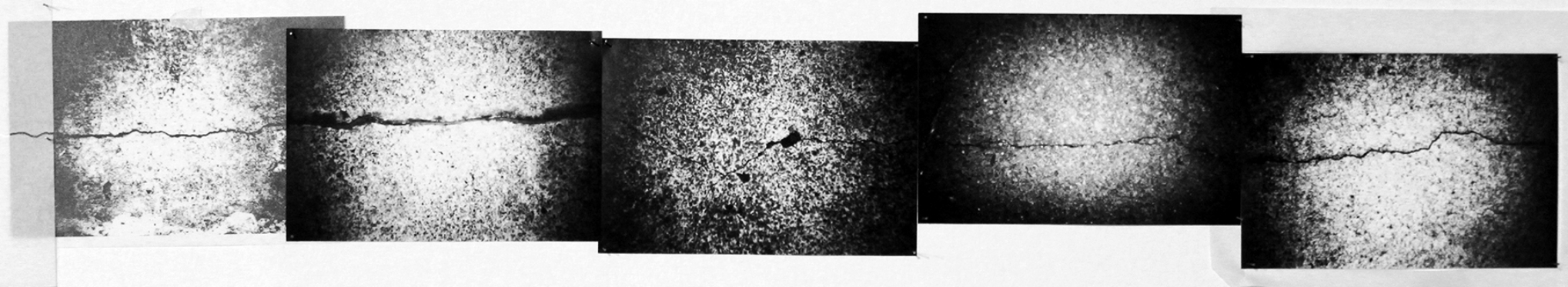

Figura 41: Gregório Soares, Pairos (detalhe), fotografia, 2014. 


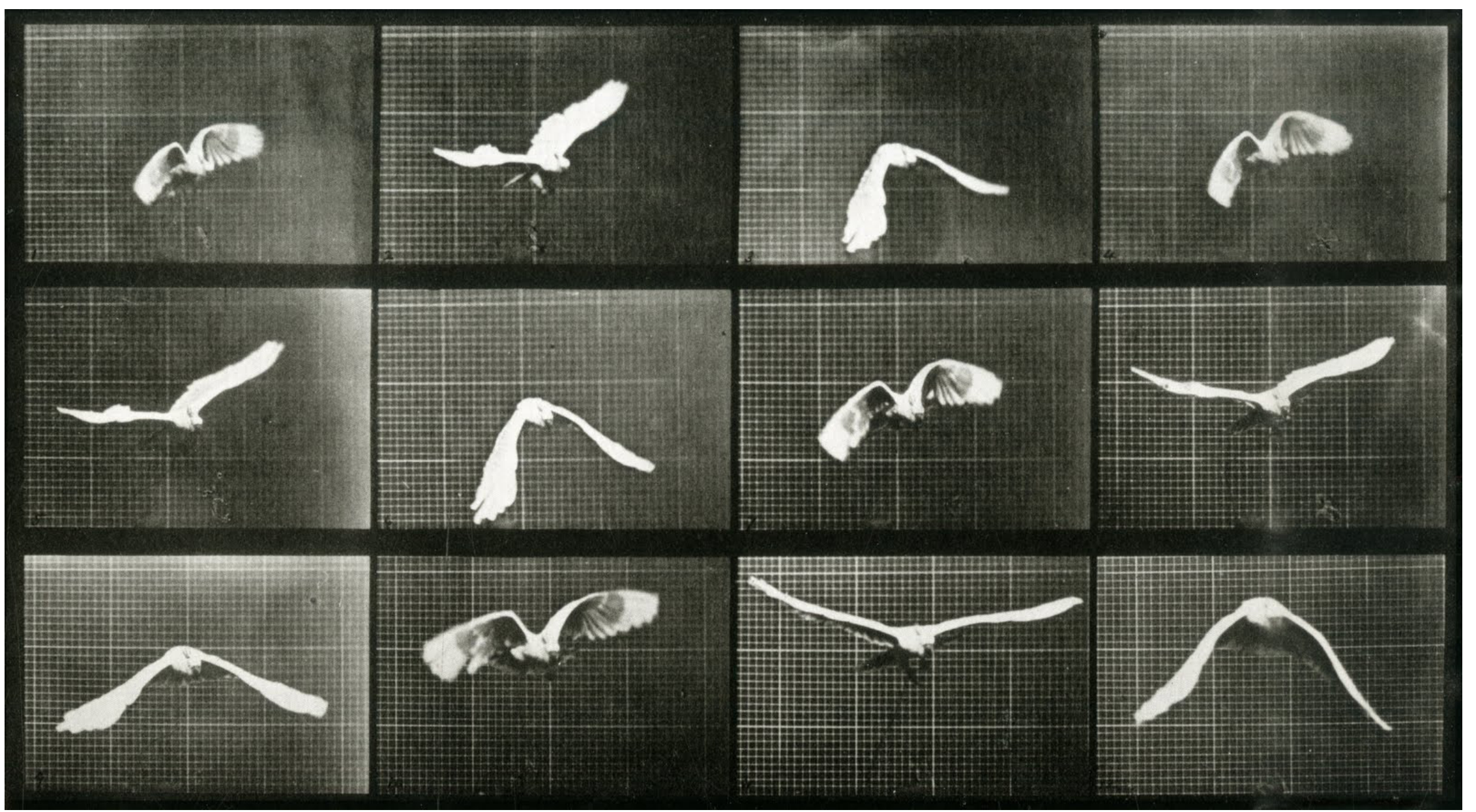

Figura 42: Eadweard Muybridge, Sequences of bird flight, 1883-86. 
Sobre "pairos" (figuras 33 a 35, 41):

Decido "deixar pairar" nos meus lábios e nos meus olhos um leve sorriso que pretendia "indefinível", no qual daria a ler, juntamente com as qualidades de minha natureza, a consciência divertida que tenho de todo o cerimonial fotográfico (Barthes, 1981, p. 26, grifos meus).

Nesta série de trabalhos há uma proposta de "pairar" junto com a foto sobre o objeto. É uma tentativa (talvez rústica) de dialogar com a tradição da fotografia aérea: transformar a cena em uma página de livro; mesmo o mais "real" se abstrai pela condição da distância específica necessária. Esse gesto, em última instância, é de "leitura", como propôs Rosalind Krauss, sobre tal tradição fotográfica (justamente, em texto sobre o registro do gesto pictórico de Jackson Pollock por Hans Namuth):

A fotografia aérea nos coloca diante de uma "realidade" transformada em texto, algo que precisa de uma leitura ou de uma decodificação. Existe uma cesura entre o ângulo de visão sob o qual foi tirado a fotografia e este outro ângulo de visão necessário para compreendê-la. A fotografia aérea desvenda portanto uma ruptura na tessitura da realidade (...) Se toda fotografia promove, aprofunda e encoraja nossa fantasia de relação direta com o real, a fotografia aérea tende a rasgar o véu deste sonho (Krauss, 2010, p. 101-102). 
Com isso, a foto se relaciona com a escrita não só pelo gesto de inscrição e incisão em um determinado suporte sensível, mas também pelo movimento $a$ posteriori da leitura. Levando em conta que provocar a experiência que é possível, capaz, pela leitura, é uma conquista para um artista visual, plástico ${ }^{62}$ : a conquista da leveza. A leitura é a capacidade de transportar o corpo, suspendê-lo com qualquer peso: fá-lo pairar.

Apesar disso, e sobretudo, a investigação sobre a leveza insiste em se manter no contraste, ou seja, relacionar-se com seu oposto: o que pesa: a fissura desenhada na rachadura do concreto ("pairos"); as marcas de estruturas de ferro ou madeira deixados sobre um terreno, como carimbos ("intermintências"); a suspensão de uma peça de gesso após a demolição de um teto ("arquipélagos verticais"); até a gravidade agindo sobre o pigmento natural (da sujeira) que escorre sobre lonas de plástico ("runas-rugas").

Esta pesquisa, do texto pesado e da leitura leve, do gesto de "pairar" sobre os objetos, é ainda, por fim, e por isso, a pergunta sobre o agir do tempo. É a tentativa de identificar um ritmo próprio das coisas: o encadear típico do movimento que "de-mora" na aparente fixidez do presente: é o exercício de identificar a música das coisas.

${ }^{62}$ Esta afirmação busca seu sentido em um contexto mais "conservador", da tradição das artes plásticas, do qual revela uma importância histórica na questão conceitual do material, carnal, concreto e físico. Portanto, sem o problema da "imaterialidade" proposta em muitas discussões contemporâneas. 
Este processo nada mais é do que a tentativa de produzir um curso de entonação com as imagens: "o nervo do discurso" (Bosi, 2000, p.77): a frase. A aproximação do movimento das imagens à música propriamente é a tentativa de uma operação predicativa: "as imagens tornam-se nomes". Segundo Alfredo Bosi, em $O$ Ser e o Tempo da Poesia, é esta característica que potencializará a dicção particular da poesia:

foi na produção [de uma 'síntese predicativa'] que o Homo loquens trabalhou, e continua trabalhando, as propriedades do sistema expiratório. (...) Sequência, força e vibração são princípios dinâmicos da frase. Supõem tempo e movimento, conaturais ambos à matéria da significação. (...) A frase resulta de um processo de significação cuja essência é a predicação e cujo suporte é a corrente de sons. (...) Uma das entradas possíveis para caracterizar o modo de ser da linguagem é, portanto, o estudo dos seus ritmos (p. 78-80).

Ou ainda:

A imagem vem transposta para a clave do signo linguístico, o qual se constitui de um ou mais significados (que o universalizam) e de um significante sonoro, que o imerge no fluxo do tempo vocal. Logo, há entre o poeta e o campo da experiência não só a mediação imagística como também as várias mediações do discurso: o tempo, o modo, a pessoa, o aspecto, faces todas que a predicação verbal configura ( $p$. 134). 
Assim, "pairar" é a tentativa de "dar a ver", no limite do paradoxo, um certo grau de sonoridade da imagem poética, ampliando e fazendo ressoar as relações entre poesia e as artes (plásticas ${ }^{63}$ ).
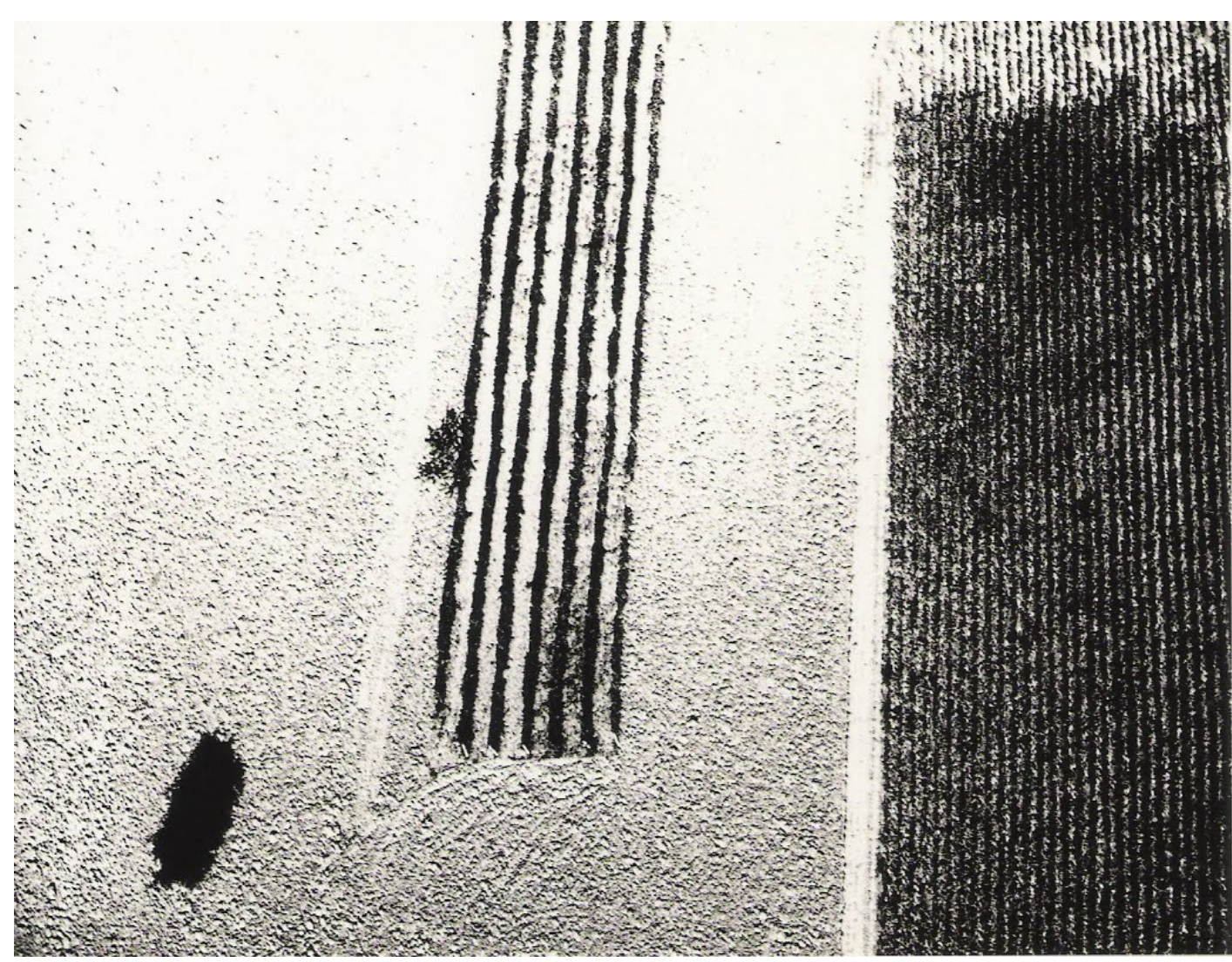

Figura 43: Mario Giacomelli (Senigallia, 1925 2000), Paesaggio, 1956-1960.

63 Talvez esta seja a questão, por fim, que supõe a separação entre as artes, bem como suas categorizações, no princípio poético, obscurecidas, ou seja, com suas definições turvas. 
Sobre "runas-rugas" (figura 38 e 39, 44):

Frontis ${ }^{64}$, ver de frente. Esta série fotográfica cinzenta ${ }^{65}$ faz menção ao conjunto dos alfabetos encontrados em pedras rúnicas ${ }^{66}$; que normalmente guardam mistérios, necessitam de um exercício de interpretação e adivinhação. Aqui, propõe-se versos mudos do movimento (o ir e o vir ${ }^{67}$ ) da imagem. Um desafio (duvidoso) à representação dessas telas rugosas, pigmentadas pelo tempo: fotografia na dimensão da poesia e da pintura ${ }^{68}$.

${ }^{64} \mathrm{Em}$ arquitetura: fachada, frente, frontão, frontispício.

65 “(...) O desagradável é que tal intermediário não seria em cores, mas cinzento... A cor da teoria. (...) As fotografias em preto e branco o provam, são cinzentas: imagens de teorias (óticas e outras) a respeito do mundo" (Flusser, 2011, p. 59).

${ }^{66}$ Relativo ao conjunto de alfabetos rúnicos, gravados em pedras, datado do ano 150, sobretudo na região histórica da Escandinávia. O significado comum das runas é "coisa secreta", "mistério".

67 "Verso quer dizer caminho de volta dentro de um conjunto verbal em que o ir e o vir demoram o mesmo tempo" (Bosi, 2000, p. 85).

${ }^{68}$ Este texto foi elaborado para apresentar a série "runas-rugas" em um portfólio impresso este ano. Esta série foi impressa em papel arroz $55 \mathrm{~g} / \mathrm{m} 2$, e elaborada para explorar a materialidade do papel e de sua pigmentação, ou seja, seu processo "pictórico". 


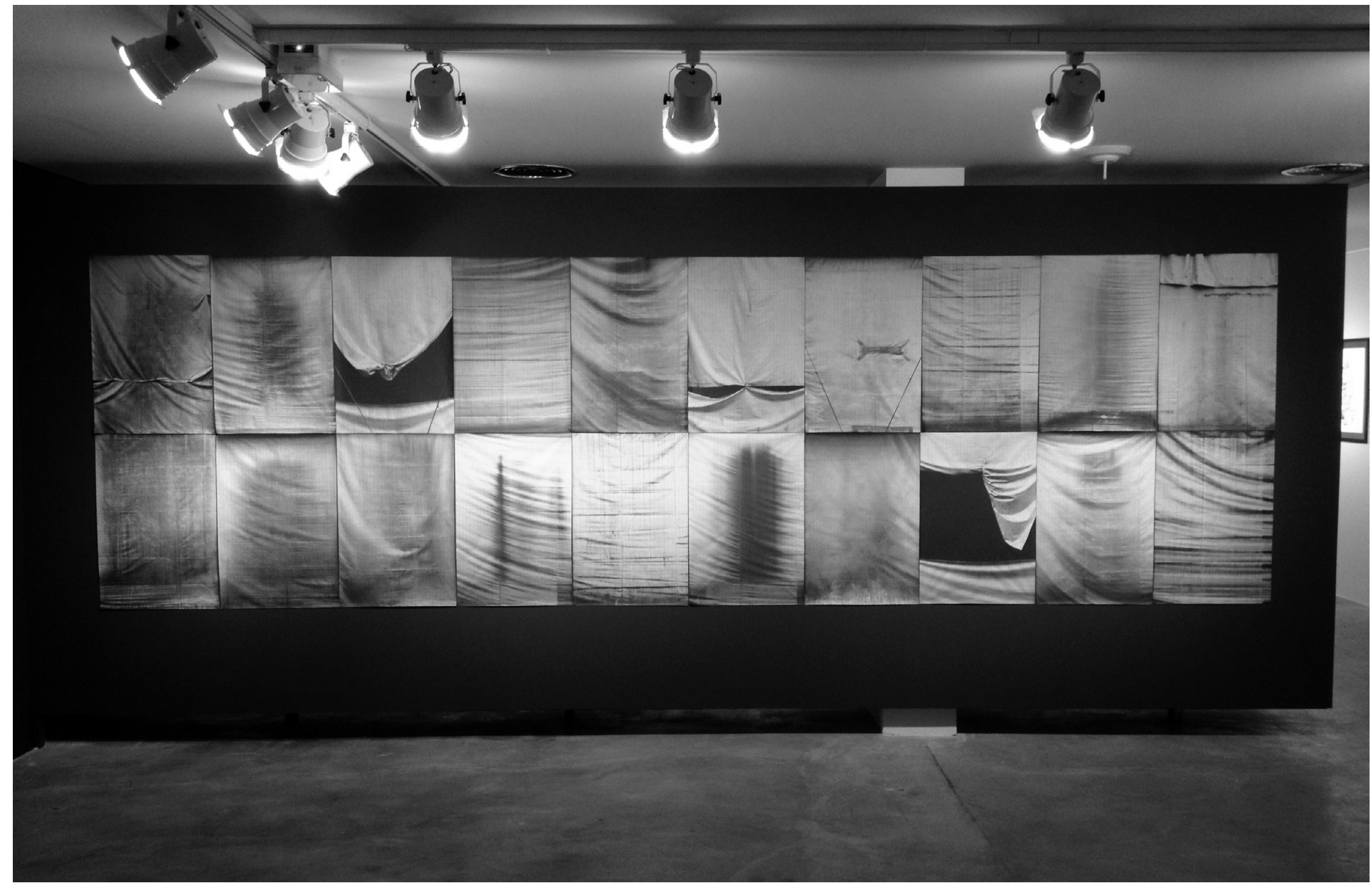


Por fim, pergunto-me ainda a partir do que Barthes diz-creve sobre o "isso, é isto..." (1981, p.17), da fotografia, como que apontando o dedo, quando a ponta do dedo avança, gesticula e trisca o que quer dizer, o discurso; E ainda, a partir do órgão em questão na foto: "Para mim, o órgão do Fotógrafo não é o olho (ele assusta-me), é o dedo" (p. 32).

Este "dedo", que "dispara" a máquina, parece o mesmo do gesto "préhistórico" do "movimento de vareta...", proposto na leitura que Jacques Derrida faz de Jean-Jacques Rousseau, em "Gênese e Escritura do Essai sur L'Origine des Langues" 69 , onde o desenho encontra, na origem, a língua escrita:

A língua hieroglífica é uma língua apaixonada. A selvajaria se mantém na máxima proximidade desta origem passional da língua. $O$ paradoxo é que assim ela se mantenha mais perto da escritura do que da fala. Pois o gesto, que em outro lugar exprime a necessidade, aqui representa a paixão. É escritura não só por traçar, como o movimento da vareta, um desenho no espaço, mas porque o significante significa de início um significante, e não a coisa mesma nem um significado diretamente apresentado. $\mathrm{O}$ grafo hieroglífico é já alegórico. $\mathrm{O}$ gesto que diz a fala antes das palavras, e que "argumenta aos olhos": eis o momento da escritura selvagem (Derrida, 2011, p. 289, grifo meu).

${ }^{69}$ Texto publicado no livro Gramatologia, de Jacques Derrida, 2011. 
Nesse exercício de ressonância entre a escrita e a fotografia, no gesto discursivo, ainda poderia citar Vilém Flusser ${ }^{70}$, com um "exemplo anacrônico" e sintomático para "ilustrar tal jogo"71:

o escritor pode ser considerado funcionário do aparelho "língua". Brinca com símbolos contidos no programa linguístico, com "palavras", permutando-os segundo as regras do programa. Destarte, vai esgotando as potencialidades do programa linguístico e enriquecendo o universo linguístico, a "literatura".

(...) O escritor informa objetos durante seu jogo: coloca letras sobre páginas brancas. Tais letras são símbolos decifráveis. Aparelhos fazem o mesmo $(2011$, p. 44-45).

E ainda sim a pergunta, ou melhor, a dúvida, permanece desde a sugestão de uma escrita selvagem ${ }^{72}$ da luz: o que a fotografia revela?

\footnotetext{
${ }^{70}$ Curiosamente o filósofo e ensaísta após escrever sobre A filosofia da Caixa Preta: Ensaios para uma futura filosofia da fotografia (1983), também se dedicaria aos problemas do futuro da escrita em A escrita - Há futuro para a escrita? (1987).

71 O aparelho, para Flusser, é um brinquedo, partícipe do jogo: “Aparelho é brinquedo e não instrumento no sentido tradicional. E o homem que o manipula não é trabalhador, mas jogador (...). (Flusser, 2011, p. 43).

72 Vilém Flusser insiste muitas vezes nessa relação "selvagem" e até "pré-histórica" do fotógrafo: "Quem observar os movimentos de um fotógrafo munido de aparelho (ou de um aparelho munido de um fotógrafo) estará observando um movimento de caça. $\mathrm{O}$ atiquíssimo gesto do caçador paleolítico que persegue a caça na tundra" (2011, p. 49).
} 
Os textos não são legendas para as fotografias. As fotografias não são ilustrações para os textos. Texto gera imagem, imagem cria texto. Não buscamos atingir um espaço de intersecção definido entre o verbal e a figuração. Antes, pontos sinuosos de confluência: onde a jurisdição da imagem expande seus limiares difusos para abarcar os territórios da palavra, e vice-versa. $O$ verso da imagem é o poema, o verso do escrito reverbera em visualidade e, desta maneira, ocupamos a materialidade da sala/galeria/página/suporte como um microcosmo do que foi, tem sido, será, sem preponderância de um tempo sobre o outro. Como na leitura de um espaço mallarmaico, não há imposição de linearidade sobre o transcorrer. Aqui, as temporalidades se movem no espaço em sobressaltos anacrônicos e são captadas como rastros ou relances nas ruínas, pequenas fagulhas narrativas que se recusam ao retesamento, preferindo o movimento mais flanável da imaginação, que se propõe interpelar o ausente e resistir à representação.

Trecho do texto realizado em coautoria com o artista Léo Tavares, para a exposição Residência L.73, na Alfinete Galeria, em Setembro de 2014. 


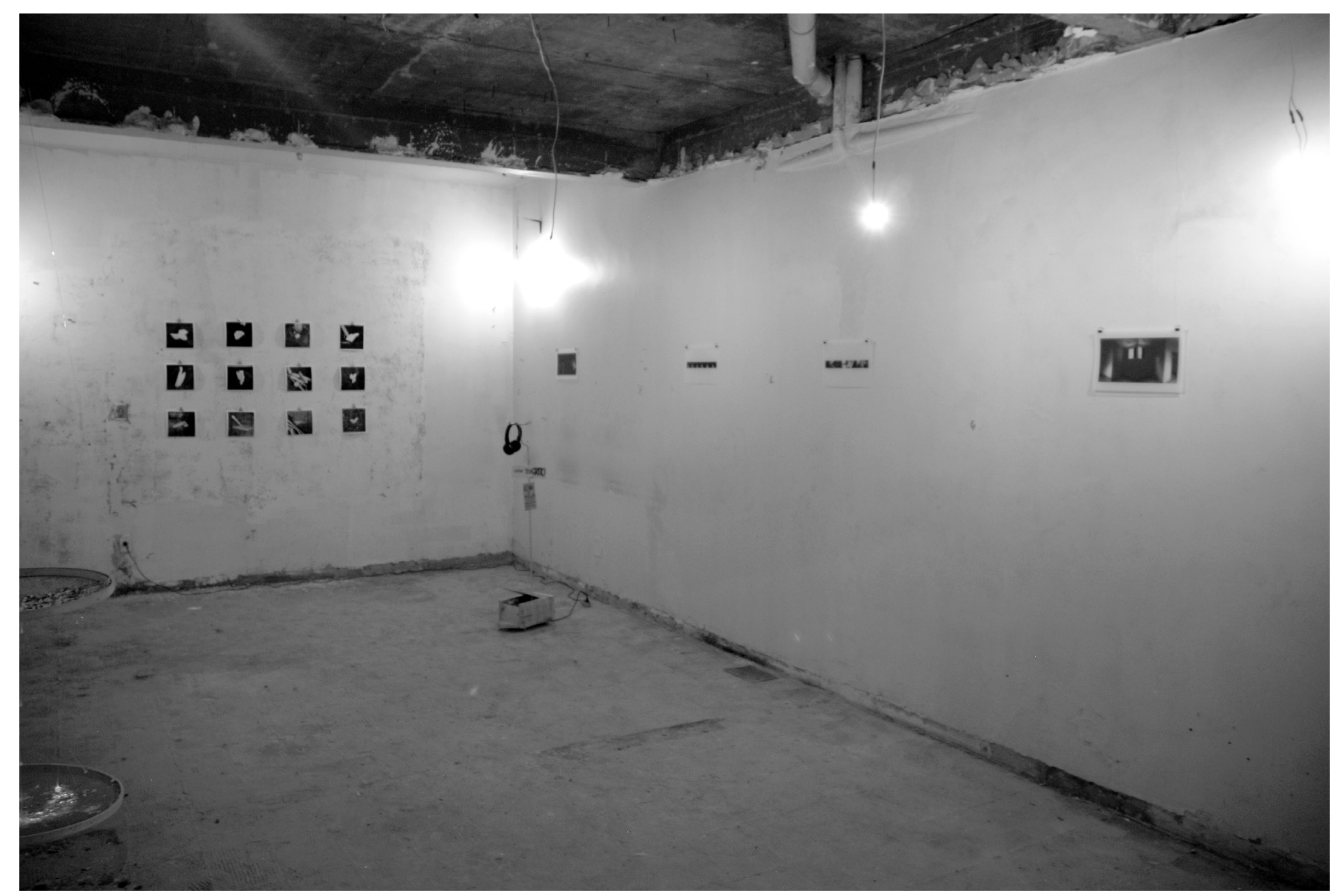

Figura 46: Residência L.73, vista da exposição, Alfinete Galeria, Brasília-DF, 2014. 


\section{Versuras finais sobre a luz-ex-crita}

a grafia-retorno da luz,

como re-volta,

como re-presença:

na impossibilidade

do novo, resta a tentativa,

gravar/far a luz,

o sentido impossível,

escavar (com) a foto,

capaz de pa(i)rar,

de voltar e

avançar num tempo outro,

no agora-fim,

fazer o tempo. 


\section{Considerações avir}

Escrever - o que eu escrevo não é escrever, é preparar-se para escrever algum dia impossível.

Augusto de Campos

O trabalho das excrivisuras chega aqui com uma única conclusão: é interminável. Pois tão somente tem a convicção de que o exercício poético e aquilo que se pode dizer e escrever (diz-crever ou até diz-crê-ver, pois é possível afirmar que existe sempre uma crença implicada na ação do dizer palavra e no mostrar imagem) sobre tal, em um determinado espaço-tempo, nunca é suficiente, resta sempre o que dizer e a mostrar, resta sempre uma pendência, avir. Mas isso nada quer dizer que o ex-crito, o já escrito, é só passado ou só uma promessa vindoura. Pelo contrário, é ruína presente. É convite à tarefa urgente do agora: o ato da leitura. É a tarefa da leitura que continuará a ex-crever (desenhar e escrever, ou descrever ${ }^{73}$ ) nas bordas dessas páginas. É nas "considerações avir" que este trabalho de fato se conclui pois aqui ele começa, pois aqui ele convida ao recomeço.

\footnotetext{
${ }^{73}$ Proponho a possibilidade de compreender a palavra "descrever" como uma palavra valise que soma o prefixo da palavra "des-enho" com o sufixo de "es-crever", forjando assim a ação comum do verbo "descrever" ("representar oralmente ou por escrito, narrar") e retomando um sentido possível, mais antigo, segundo o Dicionário de Português Licenciado para Oxford University Press, de "riscar graficamente; desenhar, traçar" e "traçar o percurso de".
} 
Ou seja, conclui-se aqui o que tentou dizer desde o início: o trabalho da escritaimagem exige sempre o "jogo" com a ruína, com aquilo que restou de algo. E por isso mesmo é uma conclusão impossível, que convida avir: ao futuro do pretérito. Aqui se registra a hipótese final do trabalho: a certeza da incerteza: o exercício de procurar por algo que não existe; que uma vez encontrado, cria novas necessidades.

Concluo ainda (sem ressalvas ou receios) que a tarefa deste trabalho foi (e ainda é, pois contínua) a proposição de uma experiência do embate da linguagem com o objeto (ou a coisa) no mundo. Por isso, e se fosse possível (tanto quanto necessário é) reescrever a introdução, seria preciso re-colocar (nas figuras-eixo-metodológicas) o que depois descobri na pesquisa sobre o "modelo ou [a] possibilidade de discurso metodológico, enquanto metalinguagem" (PIGNATARI, 1987, p. 33), que Paul Valéry formulou sobre o "método" de Leonardo da Vinci. Segundo Décio Pignatari, um "metamétodo" ou um "quase-metódo": "um método propriamente poético", onde "o chamado eixo de similaridade, paradigmático, se sobrepõe, se confunde, se projeta sobre o chamado eixo de contiguidade, sintagmático - e que é o processo da função poética da linguagem, segundo Roman Jakobson". Ora, a tentativa aqui poderia ser a mesma, sendo outra, guardadas todas as proporções, o que Valéry (sempre infalível) supôs sobre a relação entre o pintar e o filosofar (praticamente inseparáveis) de Leonardo da Vinci:

Leonardo é pintor: digo que ele tem a pintura por filosofia. 
Ele se move, de certo modo, a partir das aparências dos objetos; reduz ou tenta reduzir os seus caracteres morfológicos a sistemas de forças; uma vez conhecidos tais sistemas - re-sentidos e raciocinados - remata, ou antes, retoma (renova) o seu movimento pela execução do desenho ou do quadro, no qual recolhe todo o fruto do seu labor. Recriou, assim, um aspecto ou uma projeção dos seres, através de uma análise em profundidade de suas propriedades de toda espécie" (Valéry apud Pignatari, p. 32).

Neste "quase-método" é onde a prosa aproxima-se da poesia, é onde Pignatari conclui: “toda poesia é concreta” (p. 33). Ou seja, a matéria poética, como dito, é o objeto-concreto-mundo. É a tentativa da pesquisa que se dedica "em profundidade" pelas "propriedades de toda espécie" de seu objeto (que pode ser uma pintura, uma fotografia, um poema, uma questão teórica/histórica/crítica etc., ou um conjunto ilimitado de problemas interseccionados, como foi intentado aqui).

Assim, esta dissertação é também o resultado da consciência de que o trabalho em arte sempre ficará (ou poderá ficar) para além de nós mesmos, enquanto matéria no mundo, é o que permanece (ou poderá permanecer), em ruína, em fragmento. E toda tentativa (impossível) de leitura deste objeto (ou seja, de fazê-lo presente) e ainda o resultado da especificidade de escrever sobre (e a partir) desta imagem (da consciência de) que algo permanecerá exigindo o impossível: que tomemos posição sobre o que ocorreu e permanece ocorrendo, ruindo e resistindo 
ao tempo, e que, em última instância, os sentidos estarão sempre correndo riscos (de serem outros) na ação da des-crição na função poética. No que Lyotard propõe sobre uma escrita da paisagem, em Scapeland:

A poesia é engendrada pela compreensão dessa miséria; se assim não for, apenas é a encenação e a produção dos poderes da linguagem. Ela é a escrita da descrição impossível, a DESCRITA. E, não devemos confundir esta diferença entre descrever e contar com o diferir, a qual é a sorte atribuída ao espírito quando tenta apreender-se, quer seja pela lógica, pela teoria do conhecimento ou da literatura, pela narração ou pelo ensaio. O que está em jogo na "descrita" poética, é a matéria enquanto paisagem e não as formas pelas quais se pode inscrever. A poesia tenta não domesticar as formas que foram linguagem, não oferecer a inscrição que retém o acontecimento (da paisagem). Tenta passar antes do recuo (Lyotard, 1997, p. 188).

Talvez esta seja a tentativa (impossível) de construção de toda imagem: riscar, traçar uma linha inexistente, sem precedentes, criar uma cor sempre outra, foto-grafar sempre um instante, fixando o que não se deixa fixar, escrever uma palavra que expresse aquilo que foi visto, e tudo isso será e não será igualmente aquilo que o gesto diz quando aponta o dedo sobre a coisa. 
Por trás de tudo, portanto, o fundo, o que permanece em profundidade de campo, como em uma paisagem, enquanto desejo, o que não termina de ser almejado, é a tentativa de construir um trabalho que explore (com tudo que este verbo implica: percorrer, descobrir, experimentar, extrair etc.), até aqui, a relação entre arte e poesia, entre estas áreas da cultura que se utilizam (preponderantemente e diferentemente, cada uma, por sua vez) da palavra e da imagem, ou seja, entre estas áreas que se caracterizam pelos atos de escrever e mostrar em suas diferenças e ressonâncias. Tendo como pressuposto o que se propõe a linha de pesquisa "poéticas contemporâneas" inserida em um departamento de "artes visuais", e suas devidas exigências conceituais e formais, das quais tentei não subvertê-las, nem buscar suas contradições, mas sim, de fato, "explorar" suas possibilidades, dentro do tempo e do espaço disponíveis.

Como na fotografia de Timm Ulrichs (figura 47), precedendo "o fim", quando o olho descansa, fecha, encerra a vista, mesmo antes do fim, sugere um começo enquanto proposição que não se encerra ali. Assim também é o trabalho das excrivisuras: onde cada começo de "fim" um recomeço se faz presente. Um recomeço que estas linhas escritas esperam poder dizer (e ter dito) tanto quanto a luz do branco desta página que finda (e findará) sem fim. 


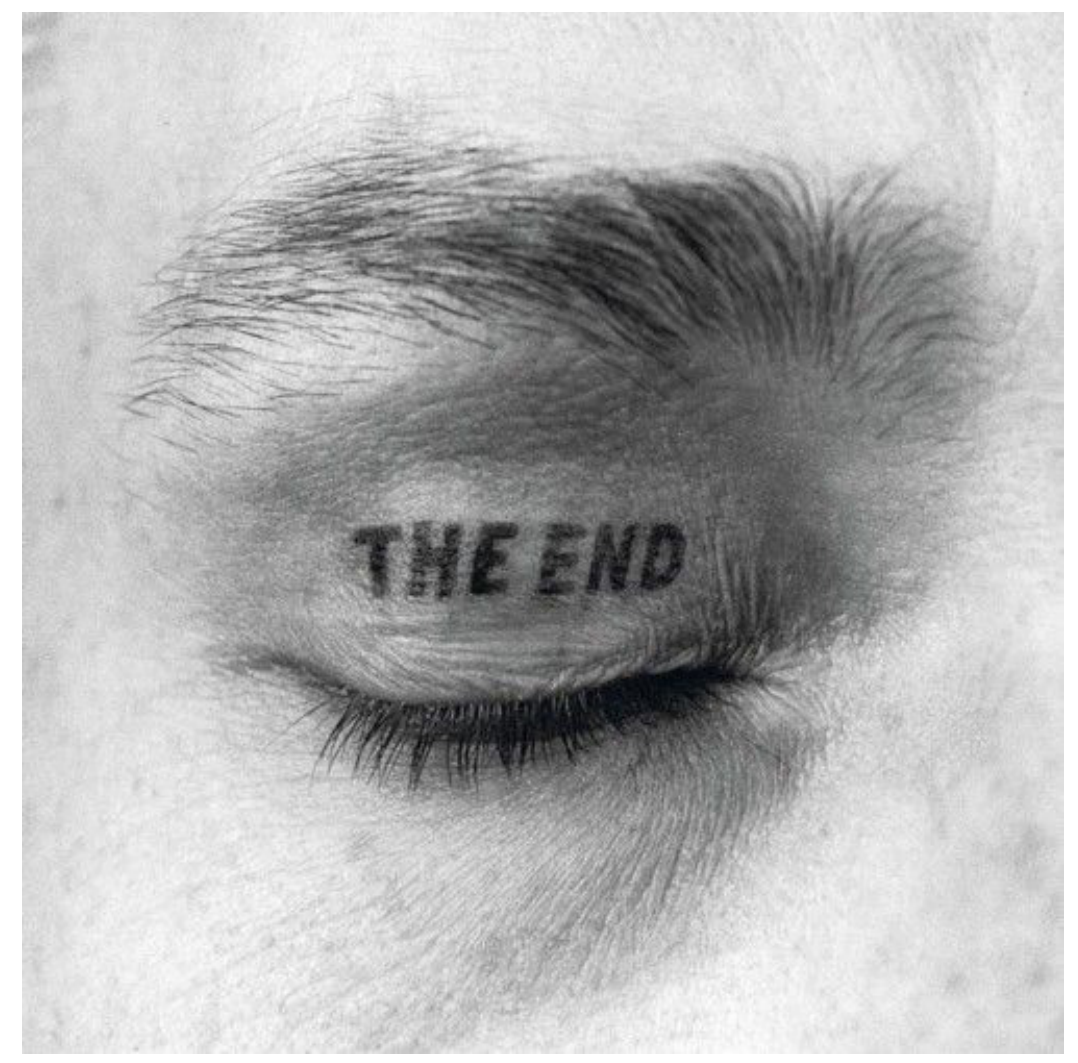

Figura 47: Timm Ulrichs, The End, 1981. 
AGAMBEN, Giorgio. A potência do pensamento: ensaios e conferências. Trad. António Guerreiro. Belo Horizonte: Autêntica Editora, 2015.

. Infância e história: destruição da experiência e origem da história. Trad. Henrique Burigo. Belo Horizonte: Editora UFMG, 2005.

ARASSE, Daniel. "Arte e Ciência: Funções do Desenho em Leonardo da Vinci". In: FABRIS, A. e KERN, M. L. B. (Orgs.). Imagem e Conhecimento. São Paulo: Editora da Universidade de São Paulo, 2006, p. 55-73.

BACHELARD, Gaston. A poética do espaço. Trad. Antonio de Pádua Danesi. 2a Edição. São Paulo: Martins Fontes, 2008.

BARTHES, Roland. A câmara clara. Lisboa: Edições 70, 1981.

O Império dos Signos. Trad. Leyla Perrone-Moisés. São Paulo: Martins Fontes, 2007.

BASBAUM, Ricardo. Manual do artista-etc. Rio de Janeiro: Beco do Azougue, 2013.

BENJAMIN, Walter. Origem do drama barroco Alemão. São Paulo: Ed. Brasiliense, 1984.

BERGSON, Henri. Matéria e Memória. Ensaio sobre a relação do corpo com o espírito. Tradução: Paulo Neves - São Paulo: Martins Fontes, 1999.

BLANCHOT, Maurice. A conversa infinita - 1. Trad. Aurélio Guerra Neto. São Paulo: Escuta, 2010.

BOSI, Alfredo. O ser e o tempo da poesia. São Paulo: Companhia das Letras, 2000.

CALVINO, Italo. Os amores difíceis. Trad. Raquel Ramalhete. São Paulo: Companhia 
das Letras, 2013.

CAMPOS, Haroldo de. A Arte no horizonte do provável. São Paulo: Perspectiva, coleção Debates, 1977.

. Pedra e Luz na Poesia de Dante. Rio de Janeiro: Imago Ed., 1998.

CARONE, Modesto. Em busca de um conceito de montagem. 1973. Disponível em: http://www.revistas.usp.br/discurso/article/view/37752/40479. Acessado em 25 de maio de 2015.

CASADEI, Eliza Bachega. Narrativas Mise en Abyme: a instalação de uma competência genérica da reportagem na Revista Da Semana (1920-1945). Revista Brasileira de História da Mídia (RBHM) - v.1, n.2, jul.2012 / dez.2012 (versão online)

http://www.unicentro.br/rbhm/ed02/artigos/05.pdf , acessado em 2 de setembro de 2015.

DA COSTA, Luiz Cláudio (org.). Dispositivos de registro na arte contemporânea. Rio de Janeiro: Contra Capa Livraria / FAPERJ, 2009.

DE CERTEAU, Michel. A Invenção do Cotidiano. 1. Artes de fazer. Trad. Ephraim Ferreira Alves. 5. ed. Petrópolis: Editora Vozes, 2000.

CHAUI, Marilena. "Janela da Alma, Espelho do Mundo". In: NOVAES, Adauto (Org.). O Olhar. São Paulo: Companhia das Letras, 1988.

COELHO, Frederico. Livro ou livro-me. Os escritos babilônicos de Hélio Oiticica (1971-1978), Rio de Janeiro: EdUERJ, 2010.

CUEVAS, Tatiana. Gordon Matta-Clark - Desfazer o espaço. Catálogo da exposição realizada no Museu de Arte Moderna de São Paulo, 2010.

DUBOIS, Philippe. O ato fotográfico e outros ensaios. Campinas: Papirus, 1994. 
DERRIDA, Jacques. Gramatologia. Trad. Miriam Schnaiderman e Renato Janini Ribeiro. São Paulo: Perspectiva, Ed. da Universidade de São Paulo, 2011.

. Enlouquecer o subjétil. Trad. Geraldo Gerson de Souza. São

Paulo: Ateliê Editorial, Imprensa Oficial do Estado de SP, Fundação Editora da UNESP, 1998.

. Memórias de Cego: o autorretrato e outras ruínas. Trad. Fernanda Bernardo. Lisboa: Fundação Calouste Gulbenkian, 2010.

. "Como o desígnio, o desenho". In: MICHAUD, G., MASÓ,

J., BASSAS, J. (Orgs.). Pensar em não ver. Trad. Marcelo Jacques de Moraes. Florianópolis: Ed. da UFSC, 2012.

DIAS, Antonio. Antonio Dias: trabalhos = Arbeiten = works: 1967-1994. Ostfildern: Cantz, 1994.

DIDI-HUBERMAN, Georges. Sobrevivência dos vaga-lumes. Trad. Vera Casa Nova e Márcia Arbex. Belo Horizonte: Editora UFMG, 2011.

Diante da imagem. Trad. Paulo Neves. São Paulo: Editora 34,

2013.

EYBEN, Piero (Org.). Demoras na aporia: bordas do pensamento e da literatura. Vinhedo: Editora Horizonte, 2012.

FABRIS, Annateresa. Identidades Virtuais: uma leitura do retrato fotográfico. Belo Horizonte: Editora UFMG, 2004.

FARIAS, Agnaldo. Construtor de espaços. Athos Bulcão. Brasília: Fundação Athos Bulcão, 2009. p. 395-402.

FERREIRA, Glória; COTRIM, Cecília (Org.). Escritos de artistas, anos 60/70. Rio de Janeiro: Jorge Zahar, 2006. 
FLUSSER, Vilém. Filosofia da caixa preta: ensaios para uma futura filosofia da fotografia. São Paulo: Annablume, 2011.

A escrita - Há futuro para a escrita? São Paulo: Annablume, 2010.

FOSTER, Hal. O retorno do real: a vanguarda no final do século XX. Trad. Célia Euvaldo. São Paulo: Cosac Naify, 2014.

GEIGER, Anna Bella. Anna Bella Geiger. Fotografia além da fotografia, 1972 - 2008. Caixa Cultural Brasília, 2010.

GIANNOTTI, Marco. A imagem escrita. Revista ARS USP, v. 1, no 1, 2003.

HERKENHOFF, Paulo. Para ver melhor Athos Bulcão. Apresentação da exposição individual Pinturas, Máscaras e Objetos, Rio de Janeiro, 1987. (versão online) http://www.fundathos.org.br/pdf/Apresentacao\%20da\%20expo\%20Pinturas,\%20 Mascaras\%20e\%200bjetos\%20-\%20Paulo\%20Herkenhoff\%20port.pdf , acessado em 20 de agosto de 2015.

JACQUES, Paola Berenstein. Estética da ginga: a arquitetura das favelas através da obra de Hélio Oiticica. 2a Edição. Rio de Janeiro: Casa da Palavra, 2003.

KRAUSS, Rosalind. O fotográfico. Barcelona: Editorial Gustavo Gili S/A, 2002. LYOTARD, Jean-François. O inumano: considerações sobre o tempo. 2. ed. Lisboa: Editorial Estampa, 1997.

MARTINEZ, Vicente. Armadilhas para poeira e luz. Brasília: Programa de Pósgraduação em Arte da Universidade de Brasília, 2008.

MERLEAU-PONTY, Maurice. O visível e o invisível. São Paulo, Ed. Perspectiva, 1992. NANCY, Jean-Luc. Apertura dell'aporia. In: EYBEN, Piero (Org.). Pensamento intruso: Jean-Luc Nancy \& Jacques Derrida. Vinhedo: Editora Horizonte, 2014. 
Janeiro, 2013.

Fazer, a poesia. Alea: Estudos Neolatinos, vol. 15, núm. 2. UFRJ:

Rio de Janeiro, 2013.

NOGUEIRA, Alexandre S. de A. O desvio como método a partir da ideia de infância: uma conversação com a infância em Berlim por volta de 1900 de Walter Benjamin. 2004. 139f. - Dissertação (Mestrado) - Universidade Federal do Ceará, Programa de Pós-graduação em Filosofia, Fortaleza (CE), 2004, disponível em: http://www. repositorio.ufc.br/handle/riufc/6472 .

PÉCORA, Alcir. Um lugar sob o sol e além. Disponível em: http://www.revistatropico. com.br/tropico/html/textos/3013,1.shl e acessado em: 2 de outubro de 2015.

PIGNATARI, Décio. Semiótica \& Literatura. 3 ed. São Paulo: Cultrix, 1987.

PONGE, Francis. Métodos. Trad. Leda Tenório da Motta. Rio de Janeiro: Imago, 1997.

REY, Sandra. "Por uma abordagem metodológica da pesquisa em artes visuais". In: BRITES, Blanca; TESSLER, Elida (Org.). O meio como ponto zero: metodologia da pesquisa em artes plásticas. Porto Alegre: Ed. UFRGS, 2002.

RIVERA, Tania. Hélio Oiticica e a arquitetura do sujeito. Niterói: EdUFF, 2012.

SONTAG, Susan. Sobre la fotografía. México: Santillana Ediciones Generales, 2006.

WISNIK, Guilherme. A "anarquitetura" de Matta-Clark, 2006. (versão online) http:// www1.folha.uol.com.br/fsp/ilustrad/fq2310200611.htm, acessado em 14 de setembro de 2015.

WÖLFFLIN, Heinrich. Conceitos Fundamentais de História da Arte. São Paulo: Editora Martins Fontes, 2006. 